\title{
The Lost Compromise: Reassessing the Early Understanding in Court and Congress on Incorporation of the Bill of Rights in the Fourteenth Amendment
}

\author{
BRYAN H. WILDENTHAL*
}

This article proposes to overturn more than a century of conventional wisdom regarding the early understanding on whether the Fourteenth Amendment incorporates the Bill of Rights and applies it to the states. The prevailing orthodox view is that Justice Miller's 5-4 majority opinion in the SlaughterHouse Cases (1873) rejected incorporation and gutted the Privileges and Immunities Clause. Professor Wildenthal contends, however, that total

\footnotetext{
* Associate Professor of Law, Thomas Jefferson School of Law, San Diego, California. A.B., 1986, J.D., 1989, Stanford University. I dedicate this article with love and admiration to the judge for whom I had the honor of clerking immediately after law school on the U.S. Court of Appeals for the Eleventh Circuit, the Honorable Frank Minis Johnson, Jr. (Oct. 30, 1918July 23, 1999). See generally JACK BASS, TAMING THE STORM: THE LIFE AND TMMES OF JUDGE FRANK M. JOHNSON, JR. AND THE SOUTH'S FIGHT OVER CIVIL RIGHTS (1993); FRANK SIKORA, THE JUDGE: THE LIFE AND OPINIONS OF ALABAMA'S FRANK M. JOHNSON, JR. (1992). A towering figure in both American law and the Second Reconstruction of America's South, he became for me, as for his legion of other law clerks, a mentor and friend we will never forget. Given the historical subject matter of this article, the Judge would have been proud, I know, to share this dedication with his great-grandfather Francis Marion Treadaway, Confederate soldier and Reconstruction-Era Republican Sheriff of Fayette County, Alabama, who courageously battled the Ku Klux Klan and upheld the rule of law when the Fourteenth Amendment was young. See BASS, supra, at 5-8; SIKORA, supra, at 71-77; ALLEN W. TRELEASE, WHITE TERROR: THE KU KLUX KLAN CONSPIRACY AND SOUTHERN RECONSTRUCTION 267-69, 306, 410 (1971); see also infra note 113. I will always be grateful to my high school American history teacher Patricia Puckett, who first inspired my interest in the Reconstruction Era and its idealistic legacy for our nation. I presented a talk on this article at Thomas Jefferson School of Law on September 29, 1999, and I thank the participants from all three San Diego law schools for their feedback. For their generosity in reviewing and commenting upon the article, I especially thank (while of course taking full blame myself for any errors or eccentricities herein): Dean Richard Aynes of University of Akron School of Law; Associate Dean Daniel Farber of University of Minnesota Law School; Professor John Hart Ely of University of Miami School of Law; Professor Ronald Krotoszynski of Washington and Lee University School of Law; Associate Dean Marybeth Herald and Professor Susan Tiefenbrun of Thomas Jefferson School of Law; Professor Emeritus Harold Hyman of Rice University History Department; and above all, Professor Michael Kent Curtis of Wake Forest University School of Law, whose encouragement was especially heartening. I also thank Thomas Jefferson School of Law and Dean Kenneth Vandevelde for a summer stipend to complete this article. Finally, I owe a very special thanks to Thomas Jefferson School of Law librarians Brent Bernau and Dorothy Hampton, and library assistant John Fernandez, for their tireless and cheerful help in locating and working with various nineteenth-century briefs, congressional records, and treatises.
} 
incorporation via that Clause may have been a minimum compromise view accepted by all the Justices in Slaughter-House. The article builds in part on prior scholarly work suggesting and developing this reading of the opinions themselves, and supports that reading by analyzing sources previously untapped in this regard. These sources include briefs and arguments presented to the Supreme Court and, most dramatically, debates in Congress during 1873-74. The latter debates reveal that the decision was read in an incorporationist light by lawyer-politicians across the political spectrum, including (indeed, especially) by the most conservative, anti-Reconstruction Southern Democrats. Indeed, the notion that the Fourteenth Amendment at least applies all textual Bill of Rights guarantees to the states, and that even the Slaughter-House majority embraced such a view, appears to have briefly emerged as a baseline consensus during the early 1870s. In a series of cases in the mid-to-late 1870s, however-most notably Edwards v. Elliott (1874), Walker v. Sauvinet (1876), and United States v. Cruikshank (1876)-the Supreme Court undermined and seemed to abandon the incorporation theory. Professor Wildenthal explores the previously unrecognized degree of discontinuity, poor or nonexistent reasoning, and outright procedural impropriety in the latter cases. He also speculates about what might have caused the incorporation "compromise" to become lost. The article concludes by suggesting that this historical evidence should place the incorporation theory on a stronger foundation in the modern Court, which recently signalled, in Saenz v. Roe (1999), a willingness to re-examine and give new life to the Fourteenth Amendment Privileges and Immunities Clause. In a sequel to this article, forthcoming in the next issue of the Ohio State Law Joumal, Professor Wildenthal pursues the treatment of the incorporation theory on the Supreme Court after 1880, culminating in Twining v. New Jersey (1908). 


\section{TABLE OF CONTENTS}

I. INTRODUCTION: PICKING UP THE THREADS OF AN OLD

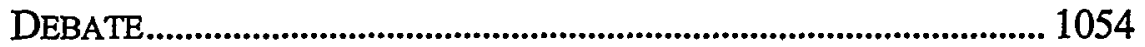

A. The Need For Reassessment: Saenz v. Roe, SlaughterHouse, and the Future of the Fourteenth Amendment Privileges and Immunities Clause 1055

B. An Overview of the Debate on the Original Understanding 1067

II. THE ENIGMA OF SLAUGHTER-HOUSE 1079

A. Introduction and 1868-1873 Developments. 1079

B. Article IV and the Equal-Rights-Only Theory 1085

C. Justice Field vs. Justice Miller. 1094

D. Justices Bradley and Swayne and the Briefs.

E. The Textual Incorporation Compromise.

III. THE POST-SLAUGHTER-HOUSE UNDERSTANDING: THE UNRAVELING CONSENSUS.

A. The Understanding in Congress.

1. The Civil Rights Bill Debates of 1873-1874

2. The Blaine Amendment Debates of 1876

3. Cooley's Views.

4. Conclusion

B. The Confusion in the Supreme Court, Part 1: Edwards and Walker.

C. The Confusion in the Supreme Court, Part 2:

Cruikshank.

IV. CONCLUSION: MAKING SENSE OF THE PUZZLE AND LOOKING AHEAD 
The question may be asked, [i]s [the Fourteenth Amendment Privileges and Immunities Clause] not dangerous to the States? My answer is, no; that it involves no danger to the States or to State rights. For what does it amount to ... ? Simply this: that rights which the citizen of the United States enjoys under the Federal Constitution, and which the Federal Government cannot deprive him of, shall not be abridged by the State. In other words it is an extension of the guarantees of liberty and of the Bill of Rights... preventing the States themselves from depriving their citizens of those guarantees.... If [that] is not the true reading of that amendment, then [the Privileges and Immunities Clause] either means nothing, or it means much more than the people of the United States ever intended....

\section{INTRODUCTION: PICKING UP THE THREADS OF AN OLD DEBATE}

This article revisits the most durable and ceaselessly provocative controversy in American constitutional law: the Great Debate over "incorporation," or whether and to what extent the Fourteenth Amendment applies to the states the guarantees of the federal Bill of Rights. ${ }^{2}$ That debate has turned in part on the proper scope of the Privileges and Immunities Clause of the Fourteenth Amendment. ${ }^{3}$ In particular, this article revisits the debates and decisions bearing

12 CONG. REC. app. 244 (Apr. 30 \& May 4, 1874) (Sen. Thomas M. Norwood, D-Ga.).

${ }^{2}$ See U.S. CONST. amends. I-VIII, XIV. The Ninth and Tenth Amendments do not enter into the discussion for the most part, since they do not refer to any particular individual rights. See U.S. CONST. amends. IX-X. On the other hand, the Constitution does contain additional references to individual rights outside the first ten amendments. See infra note 94.

${ }^{3}$ Section 1 of the Fourteenth Amendment, with which this article is concemed, reads in full:

All persons born or naturalized in the United States, and subject to the jurisdiction thereof, are citizens of the United States and of the State wherein they reside. No State shall make or enforce any law which shall abridge the privileges or immunities of citizens of the United States; nor shall any State deprive any person of life, liberty, or property, without due process of law; nor deny to any person within its jurisdiction the equal protection of the laws.

U.S. CONST. amend. XIV, $\S 1$. The Privileges and Immunities Clause consists of the words: "No State shall make or enforce any law which shall abridge the privileges or immunities of citizens of the United States...." Id. Aside from the substantive debates over the Clause's meaning, there seems to be a parallel semantic debate over how to refer to it. The commonly seen shorthand "Privileges or Immunities Clause" strikes me as awkward, suggesting uncertainty as to whether it is the "Privileges Clause" or the "Immunities Clause." The Clause itself uses "or" merely because of a happenstance of phrasing, since it provides that "[ $n]$ o State shall" violate either the "privileges" or the "immunities" of United States citizens. Because the Clause therefore protects both "privileges" and "immunities," the more sensible shorthand, conveying its substantive meaning, is the "Privileges and Immunities Clause." This also has the 
on incorporation between 1868 and 1880, in the Supreme Court and Congress. ${ }^{4}$ This article proposes a fundamental reassessment of that misunderstood history, with potentially far-reaching implications for the Court's future constitutional case law.

\section{A. The Need For Reassessment: Saenz v. Roe, Slaughter-House, and the Future of the Fourteenth Amendment Privileges and Immunities Clause}

The incorporation debate, at a superficial level, seems settled today as a matter of black-letter law. Not since 1969 has the Court either included or excluded from the scope of the Fourteenth Amendment any provision of the Bill of Rights. ${ }^{5}$ But the modern Court has failed to articulate a coherent rationale for its approach. It has come to rest by uneasy compromise on the awkward and textually untenable theory of "selective incorporation" via the Due Process Clause of the Fourteenth Amendment. ${ }^{6}$

virtue of consistency with the Article IV Privileges and Immunities Clause (from which the Fourteenth Amendment Clause was derived), which refers to "Privileges and Immunities of Citizens." U.S. CONST. art. IV, $\S 2$, cl. 1 (emphasis added). There is, of course, a need to distinguish between the two Clauses, which have quite different meanings, see infra Part II.B, but simply substituting "or" for "and" would hardly serve that purpose adequately.

${ }^{4} \mathrm{~A}$ sequel to this article revisits the incorporation debate in the Supreme Court from 1880 to 1908. See Bryan H. Wildenthal, The Road to Twining: Reassessing the Disincorporation of the Bill of Rights, 61 OHo ST. L.J. (forthcoming Nov. 2000) [hereinafter Wildenthal, Road to Twining] (manuscript available from author upon request).

${ }^{5}$ See Benton v. Maryland, 395 U.S. 784 (1969).

${ }^{6}$ See U.S. CONST. amend. XIV, $\$ 1$ ("No State shall... deprive any person of life, liberty, or property, without due process of law ...."); see also, e.g., Dumcan v. Louisiana, 391 U.S. 145, 147-50 \& n.14 (1968) (discussing selective incorporation approaches). Incorporation via the Due Process Clause of substantive liberties set forth in the Bill of Rights, such as freedom of speech under the First Amendment, makes little more sense than "Lochner-style" incorporation of substantive economic liberties. Cf. Lochner v. New York, 198 U.S. 45 (1905); JOHN HART ELY, DEMOCRACY AND DISTRUST: A THEORY OF JUDICIAL REVIEW 14-21 (1980) (criticizing "substantive" interpretations of Due Process Clause); id. at 25 (noting of Privileges and Immunities Clause that "no other clause could plausibly serve as the vehicle for incorporating the entire Bill of Rights"); id. at 194 n.52 (noting that "Due Process Clause can be seen as an apt vehicle for incorporating those provisions of the Bill of Rights that relate to 'process"'). It may be less troublesome as an exercise of judicial power, since the liberties are drawn from established constitutional text rather than out of thin air by a judge's personal view of what is "fundamental," but it seems no less oxymoronic-"sort of like 'green pastel redness," in Dean Ely's apt phrase. ELY, supra, at 18; see also 1 LAURENCE H. TRIBE, AMERICAN CONSTITUTIONAL LAW \$ 7-5, at 1317-20 (3d ed. 2000) [vol. 1 hereinafter cited as TRIBE 2000; vol. 2 is not yet published] (discussing problematical character of incorporating Bill of Rights guarantees via substantive due process); Stanley Morrison, Does the Fourteenth 
Furthermore, one can never be entirely sure that the incorporation debate on the Court is, in fact, settled. The application of a number of federal constitutional rights to the states remains in doubt. ${ }^{7}$ Though the danger perceived by some in the 1980s that the Court might roll back existing pro-incorporation precedents 8 seems to have receded, ${ }^{9}$ the Court will eventually be confronted by the issues that remain open. The uneasy rationale underlying the current precedents will then undergo uncomfortable scrutiny. After all, the majority in Twining $v$. New Jersey 10 presumably believed that it had settled the issue for all time-and indeed, it took fifty-six years for Twining to be overruled. ${ }^{11}$ The need to reassess the historical and constitutional foundations of incorporation doctrine is thus ever more apparent.

A careful reexamination of the Court's historical case law is critical to that enterprise. Every constitutional provision develops meaning through interpretation over time in the Court's accumulated decisions. How courts steeped in the common law tradition should carry on that process is a difficult and controversial issue. ${ }^{12}$ But that it happens and is important is undeniable. By analyzing the Court's early efforts to interpret and apply the Fourteenth Amendment, and in particular its Privileges and Immunities Clause, insight may

Amendment Incorporate the Bill of Rights? The Judicial Interpretation, 2 STAN. L. REV. 140, 162-70 (1949) (same). But see, e.g., Toni M. Massaro, Reviving Hugo Black? The Court's "Jot for Jot" Account of Substantive Due Process, 73 N.Y.U. L. REv. 1086 (1998) (defending a robustly substantive view of "due process," in an article criticizing the possible narrowing effect on that doctrine of Graham v. Connor, 490 U.S. 386 (1989)).

${ }^{7}$ See infra Part I.B; Wildenthal, Road to Twining, supra note 4, at Part V.

${ }^{8}$ See, e.g., Michael Kent Curtis, Conceived in Liberty: The Fourteenth Amendment and the Bill of Rights, 65 N.C. L. REV. 889 (1987) (remarks at Symposium: "To Endure for Ages to Come": A Bicentennial View of the Constitution).

${ }^{9}$ Even Judge Robert Bork, it seems, has mellowed. In a televised panel discussion on the occasion of the bicentennial of the Bill of Rights, responding to Professor Arthur Miller's query whether he was "bothered" by existing precedents applying most of the Bill of Rights to the states, Bork soothingly replied, "Those battles are long over. It doesn't bother me a bit." That Delicate Balance II: Our Bill of Rights-The First Amendment and Hate Speech (PBS-TV 1992) (videotaped Dec. 14, 1991).

10211 U.S. 78 (1908). Twining held that the Fifth Amendment privilege against selfincrimination did not apply to the states and marked the nadir of the incorporation theory on the Court. See U.S. CoNST. amend. V; Twining, 211 U.S. at 93-114; id. at 114-27 (Harlan, J., dissenting); Wildenthal, Road to Twining, supra note 4, at Part TV.

11 See Malloy v. Hogan, 378 U.S. 1 (1964).

${ }^{12}$ See generally, e.g., Antonin Scalia, Common-Law Courts in a Civil-Law System: The Role of United States Federal Courts in Interpreting the Constitution and Laws, and Comments by Gordon S. Wood, Laurence H. Tribe, Mary Ann Glendon, and Ronald Dworkin, in ANTONIN SCALIA, A MATTER OF INTERPRETATION: FEDERAL COURTS AND THE LAW (Amy Gutmann ed., 1997) [hereinafter A MATTER OF INTERPRETATION]. 
be gained into what the Amendment means today and what it should mean in the future.

The Court recently showed dramatic new interest in the Fourteenth Amendment Privileges and Immunities Clause, the most textually and historically plausible basis for applying all Bill of Rights guarantees to the states. Long regarded as a "dead letter,"13 the Clause, with only a single shortlived exception, ${ }^{14}$ had never in more than one hundred thirty years been the basis for any Supreme Court decision striking down any state law, until the Court decided Saenz v. Roe. ${ }^{15}$ Saenz did not involve the incorporation issue, but rather upheld a "privilege or immunity" rooted in the explicit language of the Citizenship Clause immediately preceding the Privileges and Immunities Clause: the right of "citizens of the United States" to become and to be treated as equal citizens "of the State wherein they reside."16

Most intriguingly, Justice Clarence Thomas and Chief Justice William H. Rehnquist, while disagreeing with the Saenz majority's particular application of the Privileges and Immunities Clause, criticized the Court's 1873 decision in the Slaughter-House Cases"17 for "all but read[ing] the... Clause out of the Constitution."18 Declaring that "the demise of the ... Clause has contributed in no small part to the current disarray of our Fourteenth Amendment jurisprudence," they announced themselves "open to reevaluating its meaning in an appropriate case."19 And in a comment that can only tantalize all sides of the incorporation debate, they continued: "Before invoking the Clause, however, we should endeavor to understand what the framers of the Fourteenth Amendment thought that it meant. We should also consider whether the Clause should displace, rather than augment, portions of our equal protection and substantive due process jurisprudence." 20 Indeed!

13 Morrison, supra note 6, at 144.

14 Colgate v. Harvey, 296 U.S. 404 (1935), overruled by Madden v. Kentucky, 309 U.S. $83,93(1940)$.

15526 U.S. 489 (1999).

16 See id. at 503, 510-11.

1783 U.S. (16 Wall.) 36 (1873).

18 Saenz, 526 U.S. at 521 (Thomas, J., joined by Rehnquist, C.J., dissenting). Chief Justice Rehnquist filed a separate dissent discussing only the equal citizenship issues raised by the case. Id. at 511-21 (Rehnquist, C.J., joined by Thomas, J., dissenting).

${ }^{19}$ Id. at 527-28 (Thomas, J., joined by Rehnquist, C.J., dissenting).

${ }^{20} \mathrm{Id}$. at 528 (Thomas, J., joined by Rehnquist, C.J., dissenting). For a survey of what Saenz may or may not foretell about the Court's future interpretation of the Privileges and Immunities Clause, and the Constitution generally, see Laurence H. Tribe, The Supreme Court, 1998 Term, Comment: Saenz Sans Prophecy: Does the Privileges or Immunities Revival Portend the Future-or Reveal the Structure of the Present?, 113 HARV. L. REV. 110, 182-98 (1999) [hereinafter Tribe, Saenz]. 
The examination provided by this article and its forthcoming sequel ${ }^{21}$ has not been adequately done before. The leading scholarly survey of the Court's early incorporation case law was published more than fifty years ago and leaves much to be desired. This was the 1949 Stanford Law Review article by Professor Stanley Morrison of Stanford Law School, a companion piece to the work of his Stanford colleague, Professor Charles Fairman.22 The two articles responded to Justice Hugo L. Black's famous 1947 dissent in Adamson v. California. ${ }^{23}$ Professor Fairman focused on the evidence regarding the original understanding in 1866-68 and Professor Morrison focused on the treatment of the Amendment in the Court after ratification. ${ }^{24}$

${ }^{21}$ See supra note 4.

${ }^{22}$ See Charles Fairman, Does the Fourteenth Amendment Incorporate the Bill of Rights? The Original Understanding, 2 STAN. L. REV. 5 (1949) [hereinafter Fairman]; Morrison, supra note 6. Professor Michael Kent Curtis, in his landmark book on the incorporation debate, provided a survey of some of this case law that is very useful and considerably more perceptive than Professor Morrison's. See MichaEl KeNT CurTIS, No STATE SHAll ABRIDGE: THE FOURTEENTH AMENDMENT AND THE BILL OF RIGHTS 171-96 (1986) [hereinafter CURTIS, No STATE]. The same is true of Irving Brant's immensely readable history of the Bill of Rights. See IRVING BRANT, THE BILL OF RIGHTS: ITS ORIGIN AND MEANING 318-63, 378-92 (1965). The primary focus of Professor Curtis's book, however, is on the evidence regarding the original understanding; he did not, for example, consider the alternative reading of the Slaughter-House Cases, 83 U.S. (16 Wall.) 36 (1873), and its influence discussed here. The same is the of Brant's historical narrative. Professor Akhil Reed Amar briefly discussed some of these cases in elaborating his theory of "refined incorporation," but he also did not explore the alternative reading of Slaughter-House and did not discuss many of the cases. See Akhil Reed Amar, The Bill of Rights and the Fourteenth Amendment, 101 YALE L.J. 1193, 1254-60, 1269-72 (1992) [hereinafter Amar]. Furthermore, this article and its sequel differ with Amar's analysis in some ways (although agreeing with him on certain fundamental points regarding incorporation). See, e.g., infra Part II.E (substantially agreeing with Amar's textual analysis); Wildenthal, Road to Twining, supra note 4, at Parts II.D and IV (disagreeing in part with Amar's interpretation of arguments and opinions in certain cases). Professor Robert Palmer provided an insightful analysis of two decisions discussed here, Slaughter-House and United States v. Cruikshank, 92 U.S. 542 (1876). See Robert C. Palmer, The Parameters of Constitutional Reconstruction: Slaughter-House, Cruikshank, and the Fourteenth Amendment, 1984 No. 3 U. ILL. L. REV. 739. Kevin Newsom's recent article also discussed Slaughter-House and Cruikshank, along with several other cases treated here. See Kevin Christopher Newsom, Setting Incorporationism Straight: A Reinterpretation of the Slaughter-House Cases, 109 YALE L.J. 643 (2000). This article differs from and expands upon Palmer's and Newsom's treatments in ways summarized below in the text and described throughout.

23332 U.S. 46, 68 (1947).

24 The articles were commissioned by the newly founded Stanford Law Review. As the editors explained:

The division of work was natural. Mr. Fairman undertook to examine in detail the historical evidence to which Justice Black had appealed. ... Mr. Morrison turned to the judicial concept of the Fourteenth Amendment as formulated since its adoption. He exhaustively analyzed the 
Professor Morrison, like Professor Fairman, strove mightily to debunk Justice Black's thesis of total incorporation, accusing Black and his dissenting colleagues ${ }^{25}$ of "distort[ing] history, as well as the language of the framers, in

Court's treatment of the cases, taking into account the arguments of counsel and views of the individual Justices.

President's Page, 2 STAN. L. REv. 1, 3-4 (1949). For a fascinating account of the background of these articles and the relationship between Fairman and Justice Felix Frankfurter (Justice Black's great antagonist in the incorporation debate, see, e.g., Adamson, 332 U.S. at 59-68 (Frankfurter, J., concurring)) and Richard L. Aynes, Charles Fairman, Felix Frankfurter, and the Fourteenth Amendment, 70 CHI.-KENT L. REV. 1197 (1995) [hereinafter Aynes, Fairman \& Frankfurter]. Dean Aynes, while strongly critical of both Fairman and Frankfurter, rejected the suspicion (voiced by Justice Black himself) that Fairman, a former law student of Frankfurter's at Harvard, was somehow solicited by Frankfurter to write the article. Id. at 1205-08, 1258-59. Aynes did suggest, however, that Fairman's article "causes considerable pause as to whether he was then the disinterested scholar or the self-appointed surrogate of Justice Frankfurter in combatting the views of Justice Black." Id. at 1272. Former U.S. Secretary of State Warren M. Christopher, who was President of Volume 1 of the Stanford Law Review, see 1 STAN. L. REV. v (1948), recalled that "the idea to write on Adamson may have originated from [Professor] Morrison, in whose constitutional law class Christopher was enrolled." Aynes, Fairman \& Frankfurter, supra, at 1230 n.204.

25 Justice Black was joined without comment by Justice William O. Douglas. See Adamson, 332 U.S. at 92 (Black, J., joined by Douglas, J., dissenting). Justices Frank Murphy and Wiley B. Rutledge, writing separately, expressed "substantial agreement" with Black, id. at 123 (Murphy, J., joined by Rutledge, J., dissenting), adding only the provisos that (1) they would not limit the procedural scope of due process to other specific procedural guarantees set forth in the Bill of Rights, see id. at 124, and (2) they believed the privilege against selfincrimination had been violated in the case at bar, see id. at 124-25, a point on which Black's dissent was agnostic, see id. at 68-69 (Black, J., joined by Douglas, J., dissenting). The Murphy-Rutledge dissent in Adamson has been commonly, but inaccurately, depicted as espousing a variation on Black's approach to incorporation. Cf., e.g., GERALD GUNTHER \& KATHLEEN SULLIVAN, CONSTITUTIONAL LAW 438 n.3 (13th ed. 1997) (describing Murphy and Rutledge as taking "something of a "having your cake and eating it too' position"); LAURENCE H. TRIBE, AMERICAN CONSTITUTIONAL LAW § 11-2, at 569 (1978) [hereinafter TRIBE 1978] (describing Murphy and Rutledge as "argu[ing] that the fourteenth amendment goes beyond the Bill of Rights" and as foreshadowing protection of unenumerated substantive rights, see id. $\S 11-3$, at 569-72); LAURENCE $H$. TRIBE, AMERICAN CONSTITUTIONAL LAW $\$ \S 11-2$ to 11-3, at 774-77 (2d ed. 1988) [hereinafter TRIBE 1988] (same). In fact, Murphy and Rutledge, as noted above, were merely concemed about the procedural scope of the Due Process Clause itself (which is, of course, found in identical terms in both the Fifth and Fourteenth Amendments) and of the Self-Incrimination Clause itself. Confusion may have been created by the fact that Murphy and Rutledge did state that they were "not prepared to say that [the Fourteenth Amendment] is entirely and necessarily limited by the Bill of Rights," Adamson, 332 U.S. at 124 (Murphy, J., joined by Rutledge, J., dissenting), but this comment was simply a preface to the first proviso noted above, and, in context, clearly referred only to other specific provisions of the Bill of Rights apart from the Due Process Clause. All four Adamson dissenters thus agreed that, whatever might be the scope of particular Bill of Rights guarantees (such as the Due Process Clause itself), the states were subjected by the Fourteenth Amendment to precisely 
order to read into the Constitution provisions which they think ought to be there." $26 \mathrm{He}$ argued that the Court majority in the late nineteenth century repeatedly and thoughtfully rejected the concept of incorporation from the very outset, and he dismissed the dissenting nineteenth-century Justices' views as belated and inconsistent "afterthought[s]."27

The truth is far different. The logic of incorporation was raised early by its proponents on the Court, and with far more thoughtful and persuasive analysis than that offered by its opponents. Professor Morrison's article contains important factual errors and omissions and much of his analysis of the case law is tendentious and unpersuasive. He erroneously asserted that incorporation "did not receive the support of any Supreme Court judge until 1892. Between 1868 and 1947 , only three judges of the Court favored the doctrine, one of whom shortly recanted."28 Morrison was referring to Justices John Marshall Harlan, Stephen J.

the same limitations as the federal government with regard to all such rights. Justice Black's view that "due process" has no independent content apart from other specific guarantees found in the Bill of Rights, see, e.g., In re Winship, 397 U.S. 358, 377-86 (1970) (Black, J., dissenting), was always one of his more idiosyncratic and troubling theories (and in my view erroneous), but strictly speaking it has nothing at all to do with incorporation, because the due process guarantee applies equally in terms to both the states and the federal government.

${ }^{26}$ Morrison, supra note 6 , at 162 . Morrison's attacks on Justice Black were startlingly harsh, and quite unwarranted. For example, he accused Black of "present[ing] the evidence of what was said by a few members of Congress and ignor[ing] the rest of that body," and "not even consider[ing] the whole of Congressman [John A.] Bingham's remarks" (Bingham, R-Ohio, being the principal framer of the Amendment), such that "[t]he statements quoted by Mr. Justice Black... are wholly insufficient to outweigh the preponderance of opinion of legislators, judges, and others on the other side." Morrison, supra note 6, at 162. The implication that Justice Black had dishonestly omitted or mischaracterized congressional statements contrary to his thesis was not only untrue, it was Professor Morrison's own characterization that was misleading, since, as he must have known, there were no congressional statements "on the other side." The thrust of Professor Fairman's article, on which Morrison presumably relied in this regard, was that the well-known statements by Representative Bingham and Senator Jacob M. Howard (R-Mich.), relied on by Justice Black and supporting incorporation, were merely (according to Fairman) insufficiently corroborated by other members of Congress and other evidence. Fairman never claimed that Bingham's and Howard's views were ever expressly contradicted by their colleagues; indeed, he conceded they were not, though one has to read his article carefully to notice that. Rather, he argued essentially that their statements were isolated and outbalanced by ambiguity and silence from other members on the relevant issue. See Fairman, supra note 22, at 24-68; see also ELY, supra note 6, at $195 \mathrm{n} .56$ (observing that "Fairman's own verdict on Black's thesis does not seem to have been a good deal stronger than "not proven," and that "[t]he claim that he had proved its contrary is one that has been added by more enthusiastic advocates").

${ }^{27}$ Morrison, supra note 6, at 152. See generally id. at 143-57.

28 Id. at $159-60$. 
Field, and David J. Brewer. ${ }^{29}$ But he omitted Justices Joseph P. Bradley and Noah $\mathrm{H}$. Swayne, who had explicitly endorsed incorporation nineteen years earlier in Slaughter-House. ${ }^{30}$ Indeed, Morrison completely overlooked the true significance of the Court's first foray in Slaughter-House. ${ }^{31}$ This is troubling in an article whose burden of argument was that incorporation was an eccentric theory with few and belated adherents. And it was not an isolated slip.32

This article challenges in many ways the century-old conventional wisdom about the incorporation theory and its early treatment in the Supreme Court. The theory is often viewed as if it sprang full blown in 1947 from the mind of Justice Black, depicted by Professor Morrison as a "fighting senator" who continued on the Court "to think as a legislator rather than as a judge." ${ }^{33}$ That Justice Black

${ }^{29}$ See id. at 150-51; O'Neil v. Vermont, 144 U.S. 323, 359-65 (1892) (Field, J., dissenting); id. at 370-71 (Harlan, J., joined by Brewer, J., dissenting). Brewer was the one who later recanted. See Wildenthal, Road to Twining, supra note 4, at Part III.

${ }^{30}$ See Slaughter-House, 83 U.S. (16 Wall.) at 118-19 (Bradley, J., dissenting); id. at 124 (Swayne, J., dissenting) (joining Bradley's dissent). Bradley, however, and possibly Swayne, later seemed to abandon the theory. See infra Parts II.B-C and IV; Wildenthal, Road to Twining, supra note 4, at Part II.

${ }^{31}$ See infra Part II.

32 Morrison had earlier asserted, following a discussion of O'Neil: "Here then, in 1892, we get the first intimation from any Justice of the Supreme Court that the Fourteenth Amendment might be considered to incorporate the Bill of Rights .... If any such notion was abroad, it certainly would have been recognized by some of the Justices prior to 1892." Morrison, supra note 6, at 151; see also id. at $172 \mathrm{n.63}$ (asserting that "the only material support for the incorporation theory to be found in the Supreme Court reports prior to 1947 comes from Justices Field and Harlan"). This not only disregarded Bradley and Swayne in Slaughter-House (and some very intriguing "intimations" regarding incorporation in the majority opinion and Field's dissent, see infra Part II.C), it reflected Morrison's earlier tendentious dismissal of Justice Harlan's dissenting opinion in Hurtado v. California, 110 U.S. 516,538 (1884), which in fact was entirely consistent with, and strongly foreshadowed, Harlan's explicit embrace of total incorporation in 1892. See Morrison, supra note 6, at 14647; Wildenthal, Road to Twining, supra note 4, at Part II.B. It is difficult to excuse Morrison's omission of Bradley and Swayne, because Justice Black not only mentioned their views but quoted extensively from Bradley's opinion in the very case to which Morrison's article responded. See Adamson, 332 U.S. at 75 n.6, 120-21 (Black, J., dissenting). Morrison also emoneously stated, in discussing Slaughter-House, that "the question of whether the Amendment incorporates the Bill of Rights was not raised," and that " $t$ t] he theory [of incorporation] does not appear even to have been presented to th[e] Court in the argument of counsel until 1887." Morrison, supra note 6, at 144, 159. But see infra Part II.D.

${ }^{33}$ Morrison, supra note 6, at 140; see also id. at 162-68 (discussing the "peculiar urgency" with which Black embraced incorporation); see also RAOUL BERGER, GOVERNMENT BY JUDICLARY: THE TRANSFORMATION OF THE FOURTEENTH AMENDMENT 134 (1977) [hereinafter BERGER, GOVERNMENT] (contending that "[i]nvocation of the Bill of Rights against the states is of fairly recent origin"); id. at 136 (describing Black as "[t]he architect of the 'incorporation' theory"); ROBERT H. BORK, THE TEMPING OF AMERICA: THE POLITICAL 
was indeed an influential U.S. Senator when appointed to the Court, a hardknocks politician whose rise to power in segregationist Alabama was not without such unsavory aspects as membership in the $\mathrm{Ku}$ Klux Klan, ${ }^{34}$ may make it easier for some to dismiss his constitutional ideas. This is not the place for a full-scale defense of this complex and fascinating Justice, but many scholars find more telling his thirty-four year record on the Court of ardently defending civil liberties and racial justice, often standing almost alone-and at the cost, for example, of effective exile for many years from his beloved home state and the destruction of his son's political hopes. 35

When the elder Justice Harlan's early and critical role has been acknowledged, it has often been only to dismiss him as "an eccentric exception," 36 as if incorporation were the kind of quaint, crackpot theory one might expect from "the last of the tobacco-spittin' judges." 37 In fact, the antiincorporationist view of the Fourteenth Amendment was never persuasively explained, and it prevailed only in the face of persistent and extremely cogent dissents written or joined during the late nineteenth century by the five Justices mentioned above. ${ }^{38}$ Four of those Justices sat together on the Court from 1890 to 1892 , briefly and tantalizingly one vote short of a majority, ${ }^{39}$ eerily

SEDUCTION OF THE LAW 93-94 (1990) (stating that Black is "primarily" responsible for the view that "the federal Bill of Rights was 'incorporated' in the due process clause and so applied to state laws and actions").

34 See GeRALD T. DUNNE, HUGO BLACK AND THE JUdiCIAL REVOLUTION 60-74, 105-73 (1977); ROGER K. NEWMAN, HUGO BLACK: A BIOGRAPHY 89-263 (1994).

35 See DUNNE, supra note 34, at 324-26; NEWMAN, supra note 34, at 430, 440-44.

36 Adamson v. California, 332 U.S. 46, 62 (1947) (Frankfurter, J., concurring).

37 LOREN P. BETH, JOHN MARSHaLl HARLAN: THE LAST WHIG JustiCE 174 (1992) (quoting Justice Oliver Wendell Holmes, Jr.) (internal quotation marks omitted). As any former law clerk of the late Judge Frank M. Johnson, Jr. can testify, see supra note *, Justice Harlan was most assuredly not the "last" of the tobacco-spittin' judges.

${ }^{38}$ A sixth Justice, William B. Woods, endorsed incorporation as a circuit judge in 1871, before being elevated to the Supreme Court in 1881. See CURTIS, No STATE, supra note 22, at 171-72, 191; infra Part II.A. Justice Woods, however, appeared to abandon incorporation on the Supreme Court. See Wildenthal, Road to Twining, supra note 4, at Part II.C. Yet a seventh nineteenth-century member of the Court, Chief Justice Salmon P. Chase, also quite likely supported incorporation, though he never had occasion to express his views. See infra note 242.

39 The four Justices and their tenures were Field (1863-97), Bradley (1870-92), Harlan (1877-1911), and Brewer (1890-1910). If Justice Swayne (1862-81) had remained on the Court and lived six years longer to age eighty-five, all five would have briefly overlapped. See THE OXFORD COMPANION TO THE SUPREME COURT OF THE UNITED STATES 850, 967-68 (Kermit L. Hall ed. 1992) [hereinafter OXFORD SUPREME COURT]. Five Justices who each, at least at some point, endorsed incorporation (Field, Bradley, Swayne, Harlan, and Woods, see supra note 38) did in fact sit together on the Court for less than three weeks, from the time of Woods's entry on duty on January 5, 1881, to Swayne's retirement on January 24, 1881. If Woods had survived on the Court just three years past his actual death in 1887 at age sixty-two, 
foreshadowing the 5-4 near miss in Adamson fifty-five years later. Justice Harlan, in particular, has still not received the full recognition he is due for his passionate and eloquent vision of total incorporation, expounded over the course of three decades on the Court. ${ }^{40}$

Justice Samuel F. Miller's majority opinion in Slaughter-House has been conventionally viewed as rejecting incorporation via the Privileges and Immunities Clause, ${ }^{41}$ perhaps because the clearest language on the issue appears in one of the dissents. ${ }^{42}$ In fact, the Bill of Rights and incorporation were not even relevant to the decision, and the majority's own language was at worst ambiguous, at best powerfully supportive of total incorporation. ${ }^{43}$ Although it never again gained majority favor on the Court and will probably surprise most modern lawyers, this incorporationist reading of Slaughter-House was not unheard-of in the late nineteenth century. On the contrary, this reading was embraced even by conservative Democrats in Congress in 1873-74, soon after Slaughter-House was decided, as an alternative to more far-reaching interpretations of the Fourteenth Amendment advocated by Republicans. It was reiterated in 1887 by former Democratic Congressman John Randolph Tucker, who presented the first fully elaborated argument to the Court in favor of incorporation via the Privileges and Immunities Clause. ${ }^{44}$ And this reading of

the number of once or future incorporationists on the Court would again have reached five in 1890. See OXFORD SUPREME COURT, supra, at 938, 967-68. Bradley, however, had apparently abandoned by then his earlier support of incorporation, as Swayne may also have done prior to his retirement in 1881. See infra Parts III.B-D; Wildenthal, Road to Twining, supra note 4, at Part II. Bradley died in office on January 22, 1892, see OXFORD SUPREME COURT, supra, at 967 , leaving the pro-incorporation side to lose by $5-3$ less than three months later in the critical case of O'Neil v. Vermont, 144 U.S. 323 (1892). See Wildenthal, Road to Twining, supra note 4, at Part III.A.

${ }^{40}$ See generally Wildenthal, Road to Twining, supra note 4.

41 See, e.g., PAMELA BRANDWEIN, RECONSTRUCTING RECONSTRUCTION: THE SUPREME COURT AND THE PRODUCTION OF HISTORICAL TRUTH 61, 67-68 (1999); CURTIS, No STATE, supra note 22, at 175; GUNTHER \& SULLIVAN, supra note 25, at 421, 431; Richard L. Aynes, Constricting the Law of Freedom: Justice Miller, the Fourteenth Amendment, and the Slaughter-House Cases, 70 CHI.-KENT L. REV. 627, 653-55 (1994) [hereinafter Aynes, Miller]; Michael Kent Curtis, Resurrecting the Privileges or Immunities Clause and Revising the Slaughter-House Cases Without Exhuming Lochner: Individual Rights and the Fourteenth Amendment, 38 B.C. L. REV. 1, 71 n.249, 86 (1996) [hereinafter Curtis, Resurrecting]; John Harrison, Reconstructing the Privileges or Immunities Clause, 101 YALE L.J. 1385, 1415 (1992).

42 See supra note 30.

43 See infra Part II.

44 The 1873-74 congressional statements are discussed in Part III.A.1. Tucker's argument was made in Spies v. Illinois, 123 U.S. 131 (1887). See Wildenthal, Road to Twining, supra note 4, at Part II.D. Together with Justice Field's sardonic dissenting reference to the Bill of Rights in Slaughter-House, 83 U.S. (16 Wall.) at 111 (discussed in Part II.C), this refutes Dean 
Slaughter-House seems to have provided critical support to the three dissenting Justices who embraced incorporation via the Privileges and Immunities Clause in the 1892 case of O'Neil v. Vermont. ${ }^{45}$ This article is the first scholarly work to systematically analyze all of this contemporary evidence for the incorporationist understanding of Slaughter-House.

Slaughter-House did not, at any rate, resolve the question of incorporation via the Privileges and Immunities Clause. No majority opinion ever since, however, with only a single unsatisfactory exception, has made any serious attempt to answer that question, except by relying without meaningful analysis on the narrow conventional reading of Slaughter-House or by simply citing precedents equally devoid of independent analysis. ${ }^{46}$ Indeed, there have been only a handful of Supreme Court cases since Slaughter-House that have said anything meaningful at all about the Clause, in any regard. 47

Dean John Hart Ely, in his landmark book Democracy and Distrust, took note of this fascinating and long-overlooked incorporationist reading of Slaughter-House, though he devoted only a footnote to it and had the impression that "the majority's hint was soon forgotten." 48 It certainly may seem so from our vantage point on the threshold of the twenty-first century, but as this article suggests, this may be only because of the crushing weight of precedent. Professor William Winslow Crosskey briefly suggested the possibility of such a reading in a 1953 treatise, though he viewed Justice Miller's opinion as intentionally "ambiguous" and "evasive" in this regard.49 Professor Robert Palmer's

Aynes's assertion that "there is no evidence that any contemporary source, including Miller, understood Miller's opinion" to support incorporation. See Aynes, Miller, supra note 41, at 654. Aynes, it should be noted, shares my agreement with the incorporation theory itself. See id. at 629-32.

45144 U.S. 323, 361 (1892) (Field, J., dissenting) (citing Slaughter-House); id. at 370 (Harlan, J., joined by Brewer, J., dissenting) ("fully concur[ring]" with Field on the relevant issue); see also Wildenthal, Road to Twining, supra note 4, at Part III.A.

${ }^{46}$ See infra Parts III.B-C and IV. See generally Wildenthal, Road to Twining, supra note 4. The exception was Maxwell v. Dow, 176 U.S. 581 (1900), and even there, most of the majority's relevant discussion consisted of lengthy quotations from Slaughter-House (with minimal analysis adhering to the narrow conventional reading) and quotations and citations of later cases devoid of significant independent analysis. See id. at 586-601.

47 See infra Parts II.A and III.A (Introduction).

48 ELY, supra note 6, at 196-97 n.59.

49 See 2 WILlIAM WINSLOW CROSSKEY, POLITICS AND THE CONSTITUTION IN THE HISTORY OF THE UNITED STATES 1128-30 (1953) [hereinafter CROSSKEY, POLITICS]. Newsom, describing Crosskey as a "conventional commentator" on Slaughter-House, Newsom, supra note 22, at 657, quoted Crosskey as suggesting that Justice Miller's opinion "does indeed seem ... to "make [the] Privileges and Immunities Clause completely nugatory and useless,"” id. (quoting 2 CROSSKEY, POLITCS, supra, at 1119). But in the passage quoted by Newsom, Crosskey was referring, not to Slaughter-House alone, but generally to what "the Supreme 
pioneering 1984 article was the first extensive scholarly treatment of the Crosskey-Ely suggestions, arguing that Justice Miller meant to embrace incorporation in Slaughter-House but that the Court abandoned the idea three years later in United States $v$. Cruikshank. ${ }^{50}$ Palmer did not, however, address the contemporary evidence for this reading outside the Court's opinions themselves. ${ }^{51}$

A recent article by Kevin Newsom also defended the incorporationist reading of Slaughter-House. Newsom even argued, provocatively, that Cruikshank and other post-Slaughter-House cases may be viewed in an incorporationist light. 52 His article offered important new insights into Justice Miller's views but did not take account of important evidence both supporting and undermining the thesis.

Court has done to the... Privileges and Immunities Clause," i.e., that "the Court has consistently refused, throughout the entire eighty-two years the amendment [had then] been in force, to give to the clause any application at all." 2 CROSSKEY, POLITICS, supra, at 1119. Newsom overlooked the passage cited above, just ten pages later, in which Crosskey became, it appears, the first modern scholar to note that Miller's opinion may be read in an incorporationist light. See infra Part IV (discussing Crosskey's views).

5092 U.S. 542 (1876).

51 Professor Palmer, consistent with this article, viewed the Slaughter-House majority opinion as reflecting a moderate balance between the extremes represented by the dissenters' views on the one hand and a purely tautological reading of the Privileges and Immunities Clause on the other. See generally Palmer, supra note 22. Palmer's article, contrary to Newsom's characterization of it, was most certainly "a sustained defense" of the incorporationist view of Slaughter-House and did far more than "hint" at that reading. $C f$. Newsom, supra note 22, at 649 \& n.17 (citing, inter alia, Palmer, supra note 22). Professor Curtis dismissed Palmer's reading as "novel, but... ultimately unpersuasive." Curtis, Resurrecting, supra note 41, at 71 n.249. Professor Amar, in his 1992 article, also briefly dismissed such a reading of Slaughter-House. See Amar, supra note 22, at 1258. Dean Aynes's two-page attempt at rebutting Palmer appears to be the most significant criticism of the incorporationist reading of Slaughter-House yet published. See Aynes, Miller, supra note 41, at 653-55.

52 See generally Newsom, supra note 22. Professor Laurence Tribe also recently endorsed the incorporationist reading of Slaughter-House. See TRIBE 2000, supra note 6, § 7-3, at 1307 (citing ELY, supra note 6, and Palmer, supra note 22); Tribe, Saenz, supra note 20, at 182-84 \& nn.326, 331 (citing Newsom's then-forthcoming article, supra note 22); see also STEPHEN P. HALBROOK, FREEDMEN, THE FOURTEENTH AMENDMENT, AND THE RIGHT TO BEAR ARMS, 1866-1876, at 150 (1998); Earl M. Maltz, The Concept of Incorporation, 33 U. RICH. L. REV. 525, 529 (1999) [hereinafter Maltz, Concept]; infra note 293 (discussing Halbrook's and Maltz's treatment of the issue). Indeed, I understand from a conversation with Professor Tribe that Newsom developed the thesis of his article while working as a student research assistant on the relevant chapter in Professor Tribe's recently revised treatise (see TRIBE 2000, supra note 6). Tribe had previously accepted the conventional reading of Slaughter-House, while severely criticizing the decision so read and urging broader interpretations of the Privileges and Immunities Clause. See TRIBE 1978, supra note 25, $\S \S 7-2$ to $7-4$, at 415-26; TRIBE 1988, supra note $25, \S \S 7-2$ to $7-4$, at $548-59$. 
Most notably, Newsom did not address the congressional debates of the 1870s. Also, his reading of the post-Slaughter-House cases suffers from certain oversights and, this article concludes, is probably incorrect..$^{53}$

This article builds in part on the work of Crosskey, Ely, Palmer, and Newsom, but it has a far broader scope. It is the first scholarly work to analyze in depth the striking contemporary support for the incorporationist reading of Slaughter-House to be found in the congressional debates, as noted above. It is the first to explore the often surprising insights to be gained from careful study of the Supreme Court briefs in all the relevant cases. ${ }^{54}$ Moreover, this article and its sequel ${ }^{55}$ are the first to treat comprehensively the entire line of relevant case law from 1868 to 1908 in light of the incorporationist implications of SlaughterHouse.

The foregoing discussion summarizes the descriptive thesis of this article. It has a normative thesis, too: that the Supreme Court should have embraced, and should still embrace, the total incorporation theory suggested in Slaughter-House but abandoned in later cases. Total incorporation, far from being a radical or unwarranted interpretation of the Fourteenth Amendment, would have been, and would still be, an honorable, elegant, and profoundly reasonable compromise. Such a compromise would accommodate the far-reaching libertarian purpose and design of the Amendment, while erring (if at all) on the side of conservative

53 This article discusses and responds to Newsom's article primarily in Parts II.E, II.B-C, and IV.

${ }^{54}$ Scholars studying these nineteenth-century cases do not generally seem to have consulted the full original briefs, as opposed to the often skimpy summaries of argument published in some of the case reports. Professor Morrison's 1949 article, for example, overlooked the pro-incorporation arguments in the Slaughter-House briefs, see infra Part II.D, and in one of the defendants' briefs in United States v. Cruikshank, 92 U.S. 542 (1876), see infra Part III.C, and the fact that incorporation was not raised before the Court in Walker $v$. Sauvinet, 92 U.S. 90 (1876), see infra Part MI.B, to cite three of my surprising discoveries in the briefs, discoveries which significantly affect how we should view the case law. In each case, the cited feature of the briefs is not discernible from the summary of argument printed in the case report, but appears only from a full review of the original briefs. Professor Morrison did, on the other hand, discuss John Randolph Tucker's argument in Spies v. Illinois, 123 U.S. 131, 143-55 (1887), which is reproduced in the case report. See Morrison, supra note 6, at 147-48; Wildenthal, Road to Twining, supra note 4, at Part II.D. For three partial exceptions to the general rule, see Richard L. Aynes, On Misreading John Bingham and the Fourteenth Amendment, 103 YALE L.J. 57, 98-99 \& n.266 (1993) [hereinafter Aynes, Bingham] (discussing Slaughter-House briefs), Aynes, Miller, supra note 41, at 632-34 (same), and Newsom, supra note 22, at 658-62, 695 (same). Aynes's Bingham article, but not his Miller article, touched on the endorsement of incorporation in the Slaughter-House briefs, but only very slightly. See infra note 252 . Newsom, surprisingly, did not mention this aspect of the Slaughter-House briefs at all, nor did he discuss the Cruikshank briefs. See generally Newsom, supra note 22.

55 See supra note 4. 
textualist principles in a way that would not upset, as the Amendment's opponents feared, the fundamental federal-state balance of power. Most vexingly, it was a compromise that, however fleetingly, was within the Court's grasp, as reflected in the arguable consensus of all nine Justices in Slaughter-House. ${ }^{56}$

This article bucks the conventional wisdom that "everyone agrees"57 the Court was wrong in Slaughter-House, and that Justice Miller's majority opinion "ruthlessly eviscerated" the Privileges and Immunities Clause. 58 To the contrary, this article suggests that the majority reached the right result on the facts presented, and did so on the basis of a reasonable - though certainly debatabletheory of the Clause. This theory might best be described as "textual incorporation." But the Court's later refusal to give effect to the Clause's purpose and design in this regard, or to recognize and grasp the potential compromise suggested by Slaughter-House, was a failure of tragic and historic proportions.

\section{B. An Overview of the Debate on the Original Understanding}

It is useful, at the outset, to review the scholarly debate on the original understanding regarding incorporation during the framing and ratification of the Fourteenth Amendment in 1866-68. That is not the focus of this article, which is primarily concemed with the post-ratification understanding, but an overview helps put the matter in perspective. As noted above, Professors Fairman and Morrison launched the modern wave of scholarship on the subject in 1949.59

56 Professor Michael McConnell has also described Slaughter-House as a historic "compromise," though in a sense very different from that used in this article, not involving the incorporation issue. Professor McConnell described Slaughter-House, consistent with the narrow conventional view of the decision, as basically negating the substantive scope of "privileges or immunities" and other rights under the Amendment, while observing that "the Court maintained, in dictum, that 'the one pervading purpose' of the Reconstruction Amendments [was] 'the freedom of the slave race."' Michael W. McConnell, The Forgotten Constitutional Moment, 11 CONST. COMM. 115, 133-34 (1994) [hereinafter McConnell, Moment] (quoting Slaughter-House, 83 U.S. (16 Wall.) at 71); see also Newsom, supra note 22, at 666 (in heading to Part III.B of his article, referring to Justice Miller's Slaughter-House majority opinion as " $\mathrm{a}$ 'compromise' view of the Fourteenth Amendment"). The phrase "lost compromise" in this article's title is taken from a law school paper of that title that I wrote in 1988.

57 Aynes, Miller, supra note 41, at 627 (internal quotation marks omitted).

58 See Sanford Levinson, Some Reflections on the Rehabilitation of the Privileges or Immunities Clause of the Fourteenth Amendment, 12 HARV. J. L. \& PUB. POL'Y 71, 73 (1989); see also TRIBE 2000, supra note 6, § 7-6, at 1320-24 \& n.17 (advocating overruling SlaughterHouse, or at least its conventional reading, and summarizing scholarly attacks on SlaughterHouse majority's conventionally received reading of Clause).

${ }^{59}$ See Fairman, supra note 22; Morrison, supra note 6. Cf. John Raeburn Green, The Bill of Rights, the Fourteenth Amendment and the Supreme Court, 46 MiCH. L. REV. 869 (1948) 
Professor Fairman's article, in particular, has enjoyed great prestige over the years and has been widely viewed as a definitive refutation of the historical case for total incorporation. ${ }^{60}$ This is somewhat remarkable, since Professor Crosskey published a thorough and devastating critique of Fairman's article only five years later. ${ }^{61}$ The debate was taken up a generation later by Professor Raoul Berger on

(supporting Justice Black's incorporation theory but not undertaking any new exploration of original understanding).

${ }^{60}$ See, e.g., RAOUL BERGER, THE FOURTEENTH AMENDMENT AND THE BILL OF RIGHTS 8 , 141 (1989) [hereinafter BERGER, FOURTEENTH]; ALEXANDER BICKEL, THE LEAST DANGEROUS BRANCH 102 (1962). Cf. ELY, supra note 6, at 25 (noting but not endorsing general acclaim of Fairman's work, and opining that reliance on Fairman was no longer so "voguish"); Aynes, Bingham, supra note 54, at 58-59 (an article strongly critical of Fairman, noting traditional views of his work as "classic" and "shap[ing] much of the constitutional field," and noting that Fairman's 1949 article is "one of the most cited law review articles written since World War II'); Aynes, Fairman \& Frankfurter, supra note 24, at 1229 (describing Fairman's article as "legendary").

61 See William Winslow Crosskey, Charles Fairman, "Legislative History," and the Constitutional Limitations on State Authority, 22 U. CH. L. REV. 1, 2-119 (1954) [hereinafter Crosskey]; see also Charles Fairman, A Reply to Professor Crosskey, 22 U. CHI. L. REV. 144, 150-56 (1954) [hereinafter Fairman, Reply]. Berger termed Fairman's reply "devastating," BERGER, FOURTEENTH, supra note 60 , at 48 , but in fact it did not even attempt to respond to most of Crosskey's substantive points, consisting mostly of ad hominem attacks on him, and it misfired on most of the points it did try to make. See, e.g., Fairman, Reply, supra, at 151-52 (quite unfairly accusing Crosskey of deceptively "fudging" by suggesting various possible corrections in punctuation and grammar in the reported congressional debates). In fact, Crosskey openly and carefully explained each proposed correction, most of which are perfectly plausible and help make sense of the debates, but which in any event he left the reader free to judge on their merits. Furthermore, Crosskey's proffered corrections were in response to the unreasonable stress that Fairman placed at certain points on an ultra-literal parsing of what Crosskey noted were, after all, transcripts of oral speeches subject to slips by the speaker and mistakes by the reporter. See Crosskey, supra, at 37. It appears that Crosskey's views on incorporation may not have been taken seriously by some because he embraced the unorthodox view that Barron v. Baltimore, 32 U.S. (7 Pet.) 243 (1833), was wrongly decided and that most of the Bill of Rights was intended from the beginning to apply directly to the states. See BERGER, FOURTEENTH, supra note 60, at 47-49 (ridiculing Crosskey on this account). Crosskey's views on the original Bill of Rights formed part of the subject of his 1954 article and his 1953 treatise, see 2 CROSSKEY, POLITICS, supra note 49, which had received some blistering reviews, including one by Professor Fairman (whose 1949 article Crosskey had criticized in the treatise). See Crosskey, supra, at 2; Fairman, Reply, supra, at 144; Charles Fairman, The Supreme Court and the Constitutional Limitations on State Governmental Authority, 21 U. CHI. L. REV. 40 (1953) (reviewing 2 CROSSKEY, POLIICS, supra note 49). For more background on the Fairman-Crosskey debate, see Aynes, Fairman \& Frankfurter, supra note 24, at 1243-56. See also BRANDWEN, supra note 41, at 96-154 (discussing different frameworks of assumptions Fairman and Crosskey brought to the debate and why Fairman's argument resonated better with the prevailing views at the time of the legal and academic establishments). More recent scholarship has suggested that Crosskey's views on the original Bill of Rights, while probably incorrect, enjoy substantial historical support just as he 
the anti-incorporation side and Professor Michael Kent Curtis for the proincorporation camp. ${ }^{62}$ More recently, Professor Akhil Reed Amar has weighed in

contended, and hardly deserve ridicule. See, e.g., Amar, supra note 22, at 1198-1212. Because, as discussed in text below, Crosskey's unorthodox views in this regard were shared by Bingham and many other Civil War-Era Republicans, this may well explain why Crosskey, unlike Fairman, succeeded in making sense out of the debates surrounding the Fourteenth Amendment.

62 See BERGER, FOURTEENTH, supra note 60; BERGER, GOVERNMENT, supra note 33, at 20-51, 134-56, 230-45; CURTIS, No STATE, supra note 22; see also Robert J. Kaczorowski, Revolutionary Constitutionalism in the Era of the Civil War and Reconstruction, 61 N.Y.U. L. REV. 863 (1986); Robert J. Kaczorowski, Searching for the Intent of the Framers of the Fourteenth Amendment, 5 CONN. L. REV. 368 (1972); Tinsley E. Yarbrough, Justice Black, the Fourteenth Amendment, and Incorporation, 30 U. MIAMI L. REV. 231 (1976). Curtis's 1986 and Berger's 1989 books grew out of their earlier debate in the law reviews. See Michael Kent Curtis, The Bill of Rights as a Limitation on State Authority: A Reply to Professor Berger, 16 WAKE FOREST L. REV. 45 (1980) (responding to BERGER, GOVERNMENT, supra note 33); Raoul Berger, Incorporation of the Bill of Rights in the Fourteenth Amendment: A Nine-Lived Cat, 42 OHI ST. L.J. 435 (1981) [hereinafter Berger, Nine-Lived Cat]; Michael Kent Curtis, Further Adventures of the Nine Lived Cat: A Response to Mr. Berger on Incorporation of the Bill of Rights, 43 OHI ST. L.J. 89 (1982) [hereinafter Curtis, Response]; Michael Kent Curtis, The Fourteenth Amendment and the Bill of Rights, 14 CoNN. L. REV. 237 (1982); Raoul Berger, Incorporation of the Bill of Rights: A Reply to Michael Curtis' Response, 44 OHIO ST. L.J. 1 (1983); Michael Kent Curtis, Still Further Adventures of the Nine-Lived Cat: $A$ Rebuttal to Raoul Berger's Reply on Application of the Bill of Rights to the States, 62 N.C. L. REv. 517 (1984); see also Michael Zuckert, Book Review, 8 CONST. COMM. 149 (1991) (reviewing, inter alia, Curtis's 1986 and Berger's 1989 books); Raoul Berger, Incorporation of the Bill of Rights: A Response to Michael Zuckert, 26 GA. L. REV. 1 (1991). Scholars during the 1960 s were not entirely silent on the subject either. Compare, e.g., BRANT, supra note 22, at 318-63, 378-92 (supporting incorporation) and Alfred Avins, Incorporation of the Bill of Rights: The Crosskey-Fairman Debates Revisited, 6 HARV. J. ON LEGIS. 1 (1968) (same) with Wallace Mendelson, Mr. Justice Black's Fourteenth Amendment, 53 MINN. L. REV. 711 (1969) (opposing incorporation); Henry J. Friendly, The Bill of Rights as a Code of Criminal Procedure, 53 CAL. L. REV. 929 (1965) (criticizing manner in which Court has applied Bill of Rights to states); and Louis Henkin, "Selective Incorporation" in the Fourteenth Amendment, 73 YALE L.J. 74 (1963) (opposing total incorporation but supporting selective incorporation to some extent).

Curtis recently retumed to the issue in a comprehensive study of the historical understanding of the "privileges and immunities" of American citizens. See Michael Kent Curtis, Historical Linguistics, Inkblots, and Life After Death: The Privileges or Immunities of Citizens of the United States, 78 N.C. L. REV. 1071 (2000) [hereinafter Curtis, Historical Linguistics]. Berger also revisited the subject in a 1997 revision of his seminal 1977 book, see BERGER, GOVERNMENT, supra note 33, which added a number of supplementary notes to the original chapters. See RAOUL BERGER, Supplementary Note on Incorporation, in GOVERNMENT BY JUDICIARY: THE TRANSFORMATION OF THE FOURTEENTH AMENDMENT 174-89 (2d ed. 1997) [hereinafter BERGER, GOVERNMENT 1997]. 
on the issue, forcefully supporting incorporation on the whole, though with some important and interesting qualifications and nuances. ${ }^{63}$

To make a long story short, Crosskey and Curtis demonstrated that Fairman misunderstood the legal philosophies and premises of the Civil War-Era Republicans who secured the Fourteenth Amendment's passage, and as a result fundamentally misconstrued how the debates surrounding the proposal and ratification of the Amendment bear on the incorporation issue. ${ }^{64}$ Fairman did not

63 See generally Amar, supra note 22 (elaborating his theory of "refined incorporation"). Amar's article was itself incorporated, in substantially unchanged though doubtless refined form, in his recent book on the Bill of Rights. See AKHIL REED AMAR, THE BILL OF RIGHTS: CREATION AND RECONSTRUCTION 137-230 (1998) [hereinafter AMAR, BIL OF RIGHTS]. The book expanded on his analysis of individual Bill of Rights guarantees in light of his "refined incorporation" theory. See id. at 231-83. This article and its sequel, see supra note 4, being preoccupied with reinterpreting historical case law and related evidence with a view to challenging traditional anti-incorporation orthodoxies at a broad and systemic level, do not (for the most part) attempt to engage the nuances of Amar's theory. I look forward to pursuing that task in future articles. Useful collections of articles reviewing Amar's book have appeared in 33 U. RICH. L. REV. 289-600 (1999) and 87 GEO. L.J. 2273-2362 (1999). See, e.g., Richard L. Aynes, Refined Incorporation and the Fourteenth Amendment, 33 U. RICH. L. REV. 289 (1999); Steven G. Calabresi, We Are All Federalists, We Are All Republicans: Holism, Synthesis, and the Fourteenth Amendment, 87 GEO. L.J. 2273 (1999); Mark A. Graber, The Constitution as a Whole: A Partial Political Science Perspective, 33 U. RICH. L. REV. 343 (1999); Maltz, Concept, supra note 52; see also, e.g., Douglas G. Smith, Reconstruction or Reaffirmation?: Review of "The Bill of Rights: Creation and Reconstruction," 8 GEO. MASON L. REV. 167 (1999) [hereinafter Smith, Reconstruction or Reaffirmation?]. The year after Amar's article came out, Dean Richard Aynes published yet another devastating critique of Professor Fairman's work. See Aynes, Bingham, supra note 54. Professor Earl Maltz, an originalist scholar otherwise generally embracing a narrow view of the Fourteenth Amendment, has also, nevertheless, found strong historical support for an incorporationist understanding of the Amendment. See EARL M. MALTZ, CIVIL RIGHTS, THE CONSTITUTION, AND CONGRESS, 1863-1869, at 113-18 (1990) [hereinafter MALTZ, CIVIL RIGHTS]. Still another recent book defending the incorporationist understanding has focused on evidence that supporters of the Fourteenth Amendment were deeply concerned with protecting the right of the freed slaves to keep and bear arms. See generally HALBROOK, supra note 52.

${ }^{64}$ See Crosskey, supra note 61, at 10-84; CURTIS, No STATE, supra note 22, at 26-130; see also Amar, supra note 22, at 1198-1217, 1233-54. Curtis and Amar dismantled the extraordinarily narrow reading of the Privileges and Immunities Clause urged by Berger. While Fairman ended up conceding that the Clause probably was, in fact, understood to incorporate at least those fundamental rights "implicit in the concept of ordered liberty" (notably including free speech), see Fairman, supra note 22, at 138-39 (quoting Palko v. Connecticut, 302 U.S. 319,325 (1937)), Berger read the Clause as merely guaranteeing equal treatment with regard to a narrow category of "fundamental" (primarily property and contract) rights, thereby excluding (even from equal protection) most of the guarantees set forth in the Bill of Rights. In essence, Berger read Section 1 of the Amendment, in toto, as doing no more than constitutionalizing the narrowest possible reading of the Civil Rights Act of 1866. See BERGER, FOURTEENTH, supra note 60, at 31-36, 91-127; BERGER, GOVERNMENT, supra note 33, at 20-51, 134-56. But see 
seem to grasp the implications of certain unorthodox constitutional theories embraced by Representative John A. Bingham, Republican of Ohio, the Amendment's primary framer and leading advocate, and many other Republicans of the time. These theories included, most notably, the view that the original Bill of Rights already applied directly to the states, and hence that Barron $v$. Baltimore $^{65}$ was wrongly decided, or at any rate was an undesirable barrier to protection of individual rights against state abuses that should be overturned by constitutional amendment. ${ }^{66}$

Professor Fairman's misunderstanding is best illustrated by his bewilderment over Bingham's reliance on Barron at a key point in the debates. A Republican opponent of the Amendment, Representative Robert S. Hale of New York, objected to an early version that gave Congress power to protect "all privileges and immunities of citizens in the several States" and "equal protection in the rights of life, liberty, and property." 67 In a portion of the debate Fairman omitted, Hale seemed to argue that the first provision was unnecessary because-as Hale apparently believed, like Bingham and many other Republicans of the time-the original Bill of Rights already protected all citizens from contrary assertions of state power. ${ }^{68}$ Hale, however, overlooked the Barron decision, which Bingham viewed as an obstacle to proper enforcement of the Bill of Rights against the states. ${ }^{69}$ The very next day on the House floor, in a passage quoted by Fairman, Bingham responded to Hale by citing Barron and another case relying on it, explaining that such decisions were "exactly what makes plain the necessity of adopting this amendment."70

CURTIS, No STATE, supra note 22, at 113-30; Amar, supra note 22, at 1243-46. For Berger's reply to Amar, see Raoul Berger, Incorporation of the Bill of Rights: Akhil Amar's Wishing Well, 62 U. CINC. L. REV. 1 (1993). See also Donald Dripps, Akhil Amar on Criminal Procedure and Constitutional Law: "Here I Go Down That Wrong Road Again," 74 N.C. L. REv. 1559, 1566-92 (1996). Professor Berger died at the age of ninety-nine as this article went to press. Douglas Martin, Obituary: Raoul Berger, 99, an Expert on Constitution in 2nd Career, N.Y. TIMES, Sept. 28, 2000, at C27. The issue whether the Fourteenth Amendments Privileges and Immunities Clause can be read as merely some sort of equality guarantee, and how it relates to the original Privileges and Immunities Clause in Article IV, is discussed further in Part II.B, because that is essential to a full understanding of how the Supreme Court has interpreted the Fourteenth Amendment Clause beginning in SlaughterHouse.

6532 U.S. (7 Pet.) 243 (1833).

66 See CURTIS, No STATE, supra note 22, at 58-71, 85-91; Amar, supra note 22, at 120317, 1233-38; Crosskey, supra note 61, at 10-21, 24-44, 67-69, 72-75.

67 See Fairman, supra note 22, at 24, 29-32.

68 See Crosskey, supra note 61, at 30-33.

${ }^{69}$ See id. at 32.

70 CONG. GLOBE, 39th Cong., 1st Sess. 1089-90 (Feb. 28, 1866); CURTIS, No STATE, supra note 22, at 69-70, 100-02; Amar, supra note 22, at 1234; Crosskey, supra note 61, at 38; 
Professor Fairman, as he did throughout his article, depicted Bingham as lost in a sea of confusion at this point. ${ }^{71}$ "How did he extricate himself?" asked Fairman. "He hailed Barron ... as though it were a vindication of his position, and plunged on to worse confusion ...."72 Barron was, of course, a vindication of the point Bingham was making; it was Fairman who was hopelessly confused. ${ }^{73}$ As one commentator has succinctly observed, "[a]s a gauge of what Bingham was trying to do, it is utterly irrelevant whether he thought his amendment was needed to overcome wrongful or rightful decisions of the Supreme Court. The point that counts is that the Fourteenth Amendment was intended to overcome those decisions."74

Fairman, supra note 22, at 34 . Bingham had tried to correct Hale by citing Barron when Hale spoke the day before, but Hale, perhaps exasperated by previous interruptions, refused to yield. See Crosskey, supra note 61, at 32.

71 See Fairman, supra note 22, at 26 (suggesting Bingham was "befuddled"); id. at 31 (suggesting he was "confused" and that his "careless imprecision" shed light on "the obscurity in the thinking" of many Congressmen); id. at 54 (Bingham "show[ed] great confusion"); id at 137 (Bingham, even if "sincere," was "confused"); see also CURTIS, NO STATE, supra note 22, at 109 (noting Fairman's descriptions of Bingham, in a later treatise, as a man of "peculiar conceptions" and "confused discourse," many of whose ideas "cannot be accepted as serious propositions"). The particular "confusion" alleged by Fairman in this instance was that Bingham was supposedly misreading Barron and similar cases as "intimat [ing] that [the Bill of Rights] really extended to the states, but that Congress was without power to make the requirements effective." Fairman, supra note 22, at 34. Of course, as Professor Crosskey noted, Bingham never suggested any such reading of Barron. See Crosskey, supra note 61, at 39. It was Bingham's own view that the Bill of Rights actually applied to the states (and was, in principle, binding on state officials via their required oath to uphold the Constitution) but that the federal government lacked effective power to enforce it. Quite understandably, he viewed Barron, whatever rationale Chief Justice Marshall had asserted in the case, as simply an obstacle to "effective" enforcement. Fairman acknowledged Bingham's view, but quite obviously neither took it seriously nor grasped its implications, and seemed to make little effort to try. See Fairman, supra note 22, at 25-26; see also id. at 53 ("Marshall's Court had said [Bill of Rights guarantees] were not limitations on the states, Bingham somehow believes that they are- but we need not go over that again.").

72 Fairman, supra note 22, at 35.

73 See Crosskey, supra note 61, at 38-39; see also CURTIS, No STATE, supra note 22, at 96, 100-02. Another commentator has noted:

It is an almost certain tip-off that an historian is not approaching his or her materials with an accurate frame of reference if important historical actors make no sense at all to the historian. Important historical actors (and this was true for Bingham, [Sen. Jacob M.] Howard [R-Mich.], and others involved in the drafting and adoption of the [Fourteenth] [A]mendment) make sense to those around them; that is why they are important actors. The historian's task is to bring out their sense, not to denounce them as fools.

Zuckert, supra note 62 , at 161. See generally BRANDWEIN, supra note 41 , at 108-16 (discussing Fairman's misunderstanding with regard to Barron and Bingham).

74 BRANT, supra note 22, at 326-27. 
The implausibility of Fairman's and Berger's rejection of the original understanding supporting incorporation is perhaps best summed up by their insistence that Bingham's repeated references to "the bill of rights" 75 meant something other than what Americans have understood for more than two hundred years to be the Bill of Rights. ${ }^{76}$ Professor Crosskey demolished the argument in 1954,77 and Professor Amar administered the coup de grace in $1992 .{ }^{78}$

There has never been much the anti-incorporationists could do with the May 1866 speech by Senator Jacob M. Howard, Republican of Michigan, formally introducing the Fourteenth Amendment in the Senate on behalf of the Joint Committee on Reconstruction, which was reprinted as front-page news the next day in the New York Times. ${ }^{79}$ Senator Howard declared that the privileges and immunities protected by the Amendment would include

${ }^{75}$ See Amar, supra note 22, at 1234-35.

76 Fairman and Berger asserted that Bingham's references to "the bill of rights" meant not the first eight or ten amendments to the Constitution, but rather a combination of the Privileges and Immunities Clause of Article IV, U.S. CoNST. art. IV, $\S 2, \mathrm{cl} .1$, and the Due Process Clause of the Fifth Amendment, U.S. CONST. amend. V, which they read as much narrower than the entire Bill of Rights. See Fairman, supra note 22, at 26, 33-34, 134; see also BERGER, GOVERNMENT, supra note 33, at 141; Berger, Nine-Lived Cat, supra note 62, at 463 \& n.214. But see Fairman, supra note 22, at 34 (on same page where he asserted narrow reading of Bingham's references to "the bill of rights," quoting speech in which Bingham referred to "the bill of rights under the articles of amendment to the Constitution"). Because Bingham, like some contemporary Republicans, apparently believed that the Article IV Privileges and Immunities and Fifth Amendment Due Process Clauses together encompassed the entire Bill of Rights anyway, see CURTIS, No STATE, supra note 22, at 47-48, 61, 114-15, 149-51, 166; Amar, supra note 22, at 1229; Crosskey, supra note 61, at 11-16, this may in the end be simply another illustration of how Fairman and Berger misunderstood the legal theories under which Civil War-Era Republicans operated.

77 See Crosskey, supra note 61 , at 27-28, 39. As Crosskey asked with understandable exasperation: 'Now, who ever heard of a 'bill of rights' consisting of the Privileges and Immunities Clause of the original document, and the Due Process Clause of the Fifth Amendment?" Id. at 27.

78 See Amar, supra note 22, at 1234-35 \& n.195; see also MALTZ, CIVIL RrGHTS, supra note 63, at 114-15; Aynes, Bingham, supra note 54, at 66-74. In light of the context of Bingham's repeated use of the phrase "the articles of amendment" in conjunction with references to Barron, specific Bill of Rights guarantees from (at least) the First, Fifth, and Eighth Amendments, and statements by congressional colleagues indicating that they also used (and understood Bingham to use) the phrase in its traditional sense, Amar found it "frankly astonishing that some scholars... have suggested that ... Bingham ... didn't mean what he said." Amar, supra note 22, at 1235.

79 See CURTIS, No STATE, supra note 22, at 87, 128; Fairman, supra note 22, at 54, 68 (both citing, inter alia, N.Y. TMES, May 24, 1866, at 1). The New York Times also fully reported Bingham's earlier speeches, unambiguously conveying his understanding that the Amendment would enforce the Bill of Rights against the states. Bingham's speeches to this 
the personal rights guarantied [sic] and secured by the first eight amendments of the Constitution; such as [he then listed rights contained in the First, Second, Third, Fourth, Sixth, and Eighth Amendments] .... [I]t is a fact well worthy of attention that the course of decision of our courts and the present settled doctrine is, that all these immunities, privileges, rights, thus guarantied [sic] by the Constitution or recognized by it, are secured to the citizen solely as a citizen of the United States and as a party in their courts. They do not operate in the slightest degree as a restraint or prohibition upon State legislation.... [T]hey stand simply as a bill of rights in the Constitution, without power on the part of Congress to give them full effect; while at the same time the States are not restrained from violating...them except by their own local constitutions, which may be altered from year to year. The great object of the first section of this amendment is, therefore, to restrain the power of the States and compel them at all times to respect these great fundamental guarantees. ${ }^{80}$

Howard's views on incorporation were thus consistent with those of Bingham, the primary framer and leading House backer of the Amendment, and not a single member of either House of Congress, throughout all the debates, ever contradicted their plainly expressed understanding. 81

Scholars continue to debate what light the state ratification debates shed on the incorporation issue. ${ }^{82}$ The issue may devolve to a classic lawyer's quibble over who has the burden of proof. The anti-incorporationists contend that the

effect were also widely distributed in pamphlet form. See Aynes, Bingham, supra note 54 , at 72 \& nn.84-85 (citing, inter alia, JOHN A. BINGHAM, ONE COUNTRY, ONE CONSTTIUTION, AND ONE PEOPLE: SPEECH OF HON. JOHN A. BNGHAM, OF OHIO, IN THE HOUSE OF REPRESENTATIVES, FEB. 28, 1866, IN SUPPORT OF THE PROPOSED AMENDMENT TO ENFORCE THE BILL OF RIGHTS (1866); N.Y. TIMES, Mar. 1, 1866, at 5; id., Mar. 10, 1866, at 1).

80 CONG. GLOBE, 39th Cong., 1st Sess. 2765-66 (May 23, 1866).

81 See CURTIS, No STATE, supra note 22, at 91; Amar, supra note 22, at 1238. Antiincorporationists have tried to blunt the impact of Howard's speech by various means. Aside from denigrating Howard's abilities and clarity of thought (the same tactic used against Bingham, see supra notes 71 and 73), some have placed undue stress on the fact that he was filling in for Senator William P. Fessenden, Co-Chairman of the Joint Committee, who was ill. See, e.g., BERGER, FOURTEENTH, supra note 60, at 135-37; BERGER, GOVERNMENT, supra note 33, at 147-48; Fairman, supra note 22, at 54-57, 134 n.381. This seems to grasp at straws, because Howard was a member of the Joint Committee and thus had been privy to its discussions and was obviously trusted by his colleagues to speak in Fessenden's stead. Furthermore, his lengthy and detailed speech indicated thorough preparation and command of the issues. See CURTIS, No STATE, supra note 22, at 126-28.

82 Some scholars have argued that the evidence available from the ratification debates provides, on the whole, strong support for incorporation. See CURTIS, NO STATE, supra note 22, at 131-53; Amar, supra note 22, at 1246-54; Crosskey, supra note 61, at 100-11. Dean James Bond, focusing on the ratification debates in the southem states, has argued strenuously to the contrary. See JAMES E. BOND, NO EASY WALK TO FREEDOM: RECONSTRUCTION AND THE RATIFICATION OF THE FOURTEENTH AMENDMENT 45, 111, 180-82, 220-21, 235-38, 252-62 (1997). 
evidence (mostly in the form of silence) they find in the ratification debates outweighs the statements by Bingham and Howard (not to mention the most persuasive reading of the text ${ }^{83}$ ), because applying the Bill of Rights to the states would supposedly have been shocking and inconceivable to Americans of the day. ${ }^{84}$ Curtis and Amar have suggested powerful reasons to doubt that conclusion. 85 It is worth noting, finally, with regard to individual Bill of Rights guarantees, that even Professor Fairman conceded that there is substantial evidence supporting incorporation of First Amendment rights, especially freedom of speech. ${ }^{86}$ Indeed, it is difficult to see how any fair-minded analyst could deny that the evidence is overwhelming on that score. 87

The revolution in legal scholarship on incorporation has been accompanied and informed by the vast "revisionist" historiography on Reconstruction itself. This has shed new light on the post-Civil War Republicans and their idealistic and nationalistic views on federal civil rights enforcement. "Revisionism," of course, has a pejorative connotation suggesting a rewriting of the past, but the consensus of historians is that the revised view in this case has illuminated far

83 See infra Part II.E.

${ }^{84}$ See BERGER, FOURTEENTH, supra note 60, at 37-42, 82-87; Fairman, supra note 22, at 68-126, 137-38; Fairman, Reply, supra note 61, at 154-55. 54.

85 See CURTIS, No STATE, supra note 22, at 91, 217-18; Amar, supra note 22, at 1253-

86 See Fairman, supra note 22, at 75-77, 96-97, 116-20, 134-35, 139.

87 See CURTIS, No STATE, supra note 22, at 29-34 (discussing centrality of Republican concerns over antebellum suppression of free speech by slave states, as reflected in 1856 Republican presidential nominee John C. Frémont's campaign slogan, "Free Speech, Free Press, Free Men, Free Labor, Free Territory, and Frémont"); id. at 133-53 (discussing pervasive concerns over free speech in 1866 election campaigns, largely fought over recently proposed Fourteenth Amendment, as well as in ratification debates); id. at 217 (summarizing evidence); MALTZ, CIVIL RIGHTS, supra note 63, at 117 (concluding that "the evidence impressively demonstrates that the basic guarantees of the First Amendment were understood to be included in the concept of privileges and immunities'); Amar, supra note 22, at 1214-17 (discussing antebellum concems over free speech); id. at 1271-84 (discussing exceptionally strong historical support for incorporation of First Amendment principles in Fourteenth, except, in Amar's view, nonestablishment of religion); Avins, supra note 62, at 17-22 (canvassing evidence from congressional debates); Curtis, Resurrecting, supra note 41, at 46-47 (noting deep Republican concerns about "precious American right to free speech"); see also Michael Kent Curtis, The 1859 Crisis Over Hinton Helper's Book, The Impending Crisis: Free Speech, Slavery, and Some Light on the Meaning of the First Section of the Fourteenth Amendment, 68 CHI.-KENT L. REV. 1113 (1993); Michael Kent Curtis, The Curious History of Attempts to Suppress Antislavery Speech, Press, and Petition in 1835-37, 89 Nw. U. L. REV. 785 (1995); Michael Kent Curtis, The 1837 Killing of Elijah Lovejoy by an Anti-Abolition Mob: Free Speech, Mobs, Republican Government, and the Privileges of American Citizens, 44 UCLA L. REV. 1109 (1997); Michael Kent Curtis, Lincoln, Vallandigham, and Anti-War Speech in the Civil War, 7 WM. \& MARY BILLRTS. J. 105 (1998). 
more accurately and insightfully the true facts regarding Reconstruction. ${ }^{88}$ As Professor Amar has suggested, Professor Fairman's 1949 article, written without benefit of this later scholarship, "was remarkably insensitive to all of this and indeed, quite anachronistic.... [Justice] Black...proved the more faithful historian, for he understood - because he shared - the almost mystical attachment to the Bill of Rights exemplified by John Bingham."89

Despite the many judicial defeats of the incorporation theory and the scholarly wars spawned by Professors Fairman and Morrison, the theory has achieved a near-total practical victory in the modern Supreme Court. The "lost compromise" of Slaughter-House was ultimately resurrected, though belatedly and imperfectly, by the Warren Court of the 1960s. Of the twenty-four separate

${ }^{88}$ For some of the best modern work on the legal and judicial aspects of Reconstruction, see BRANDWEN, supra note 41, HAROLD M. HYMAN \& WILLIAM W. WIECEK, EQUAL JUSTICE UNDER LAW: CONSTITUTIONAL DEVELOPMENT, 1835-1875 (1982); ROBERT J. KACZOROWSKI, THE POLITICS OF JUDICIAL INTERPRETATION: THE FEDERAL COURTS, DEPARTMENT OF JUSTICE AND CIVIL RIGHTS, 1866-1876 (1985) [hereinafter KACZOROWSKI, POLITICS]; and WILLIAM E. NELSON, THE FOURTEENTH AMENDMENT: FROM POLITICAL PRINCIPLE TO JUDICIAL DOCTRINE (1988). See also BOND, supra note 82; JOHN BRAEMAN, BEFORE THE CIVL RIGHTS REVOLUTION: THE OLD COURT AND INDIVIDUAL RIGHTS (1988); DANIEL A. FARBER \& SUZANNA SHERRY, A HISTORY OF THE AMERICAN CONSTITUTION 247-345 (1990); JOSEPH B. JAMES, THE FRAMING OF THE FOURTEENTH AMENDMENT (1956) [heteinafter JAMES, FRAMING]; JOSEPH B. JAMES, THE RATIFICATION OF THE FOURTEENTH AMENDMENT (1984) [hereinafter JAMES, RATIFICATION]. For general treatments of Reconstruction, see ERIC FONER, RECONSTRUCTION: AMERICA'S UNFINISHED REVOLUTION, 1863-1877 (1988) (the definitive modern work); JOHN HOPE FRANKLIN, RECONSTRUCTION AFTER THE CIVIL WAR (2d ed. 1994); KENNETH M. STAMPP, THE ERA OF RECONSTRUCTION, 1865-1877 (1965); RICHARD NELSON CURRENT, THOSE TERRIBLE CARPETBAGgers (1988); and TRELEASE, supra note *. For an interesting legal and political novel of the period by a "carpetbagger" who served as a North Carolina state judge, see ALBION W. TOURGEE, A FOOL's ERRAND (John Hope Franklin ed., Harvard University Press 1961) (1879). Tourgee later represented Homer Plessy in his challenge to racial segregation. See Plessy v. Ferguson, 163 U.S. 537, 540 (1896); CHARLES A. LOFGREN, THE PLESSY CASE: A LEGAL-HISTORICAL INTERPRETATION 30, 41, 148-52 (1987). Special mention must go to W.E.B. Du Bois's heroic and pioneering work, the final chapter of which should be required reading for every American. See W.E.B. Du BoIs, The Propaganda of History in BLACK RECONSTRUCTION IN AMERICA: 1860-1880, at 711-28 (David Levering Lewis ed., Touchstone 1992) (1935) (assailing biased, and often racist, historiography of Reconstruction that prevailed up to that time).

${ }^{89}$ Amar, supra note 22, at 1241; see also AMAR, BILL OF RIGHTS, supra note 63, at 30203 (arguing that Fairman and Berger were both "very much in the grip of this [old] view [of Reconstruction]"); BRANDWEN, supra note 41, at 115-16; Aynes, Fairman \& Frankfurter, supra note 24, at 1204 (suggesting that Fairman and his mentor, Justice Frankfurter, were both influenced, as were many of their contemporaries, by the traditional "jaundiced view of Reconstruction and of the framers of the Fourteenth Amendment" exemplified by early historians like William A. Dunning, and mostly discredited by the modem "revisionist" school). 
privileges and immunities that may be parsed from the first eight amendments, 90 eighteen have been applied in substance to the states, half of them between 1961 and 1969.91 Three have specifically been found not to be applicable and remain

90 They may be numbered as follows: (1) rule against establishment of religion, (2) free exercise of religion, (3) freedom of speech, (4) freedom of the press, (5) right of peaceable assembly, (6) right of petition, see U.S. CoNST. amend. I; (7) right to keep and bear arms, see id. amend. II; (8) freedom from quartering of soldiers, see id. amend. III; (9) search, seizure, and warrant guarantees, see id. amend. IV; (10) right to grand jury indictment, (11) immunity from double jeopardy, (12) privilege against self-incrimination, (13) right to just compensation for private property taken for public use, see id. amend. V; (14) right to speedy trial, (15) right to public trial, (16) right to impartial jury trial within state and district where crime was allegedly committed, (17) right to be informed of nature and cause of accusation, (18) right to be confronted by adverse witnesses, (19) right of compulsory process to obtain favorable witnesses, (20) right to counsel, see id. amend. VI; (21) right to common law civil jury trial, see id. amend. VII; (22) immunity from excessive bail, (23) immunity from excessive fines, and (24) immunity from cruel and unusual punishments, see id. amend. VIII. The right to due process of law, see id. amend. V, is of course not at issue because the Fourteenth Amendment incorporates that specifically, see id. amend. XIV, $\S 1$. Reasonable people may of course differ on how much to "split" or "lump" these various rights. The above parsing relies on common sense, guided by how the Supreme Court has actually dealt with them. For example, one could reasonably sever the Fourth Amendment right to be free of unreasonable searches and seizures from the warrant rule, or for that matter protection against searches from protection against seizures, but the Court has in fact dealt with the Fourth Amendment as a "package" with regard to incorporation (though only later and separately incorporating the remedy of the exclusionary rule). Likewise, it is difficult to see why one would incorporate one or more but not all First Amendment rights, but the Court, while eventually incorporating all of them, did so piecemeal. See infra note 91.

91 See Chicago, Burlington \& Quincy R.R. Co. v. Chicago, 166 U.S. 226, 241 (1897) (incorporating right to just compensation for takings of private property); Gitlow v. New York, 268 U.S. 652, 666 (1925) ("assum[ing]" that freedoms of speech and press are incorporated); Stromberg v. Califomia, 283 U.S. 359, 368 (1931) (so holding as to freedom of speech); Near v. Minnesota, 283 U.S. 697, 707 (1931) (same as to freedom of press); De Jonge v. Oregon, 299 U.S. 353, 364 (1937) (incorporating rights of peaceable assembly and petition); Cantwell v. Connecticut, 310 U.S. 296, 303 (1940) (same as to free exercise of religion and rule against establishment of religion); In re Oliver, 333 U.S. 257, 266-73 (1948) (same as to right to public trial); id. at 273 (same as to defendant's "right to reasonable notice of a charge against him," i.e., right to be informed of nature and cause of accusation); Wolf v. Colorado, 338 U.S. 25, 27-28, 33 (1949) (incorporating "security of... privacy against arbitrary intrusion by the police ... at the core of the Fourth Amendment," but not exclusionary rule for evidence seized in violation thereof); Mapp v. Ohio, 367 U.S. 643, 654-60 (1961) (incorporating right to exclusion of evidence seized in violation of Fourth Amendment); Robinson v. Califomia, 370 U.S. 660, 666-67 (1962) (same as to immunity from cruel and unusual punishments); Gideon v. Wainwright, 372 U.S. 335, 342-45 (1963) (same as to right to counsel, including appointed counsel for indigent defendants); Malloy v. Hogan, 378 U.S. 1, 8-11 (1964) (same as to privilege against self-incrimination); Pointer v. Texas, 380 U.S. 400, 403 (1965) (same as to right of confrontation); Klopfer v. North Carolina, 386 U.S. 213, 222-23 (1967) (same as to right to speedy trial); Washington v. Texas, 388 U.S. 14, 17-19 (1967) (same as to right to 
unincorporated today. ${ }^{92}$ The Court has not specifically ruled on the remaining three. ${ }^{93}$ An intriguing related issue concerns the six other individual rights guaranteed by the original Constitution against the federal government, but not expressly against the states. ${ }^{94}$ Are they also properly incorporated? ${ }^{95}$ To answer such questions it is necessary, as the saying goes, to begin at the beginning.

compulsory process to obtain favorable witnesses); Duncan v. Louisiana, 391 U.S. 145, 148-50 (1968) (same as to right to criminal jury trial); Benton v. Maryland, 395 U.S. 784, 793-96 (1969) (same as to immunity from double jeopardy). The Court's incorporation of the right to counsel had its gradual start in Powell v. Alabama, 287 U.S. 45 (1932), but was not fully accomplished until Gideon. The Court in Robinson appeared to rely on Louisiana ex rel. Francis v. Resweber, 329 U.S. 459 (1947), as having already incorporated immunity from cruel and unusual punishments. See Robinson, 370 U.S. at 666; see also id. at 675 (Douglas, J., concurring). Justice Reed's plurality opinion in Resweber, however, merely "assum[ed] ... without so deciding" that this immunity was incorporated in the Fourteenth Amendment, and did not speak for the Court in any event. See Resweber, 329 U.S. at 462 (Reed, J., joined by Vinson, C.J., and Black and Jackson, JJ.). Furthermore, the majority denied relief to the claimant. See id. at 465-66 (Reed, J.); id. at 471-72 (Frankfirter, J., concurring in the judgment).

92 See Edwards v. Elliott, 88 U.S. (21 Wall.) 532, 557 (1874) (civil jury trial); Walker v. Sauvinet, 92 U.S. 90, 92-93 (1876) (same); United States v. Cruikshank, 92 U.S. 542, 553 (1876) (right to bear arms); Presser v. Illinois, 116 U.S. 252, 264-68 (1886) (same); Hurtado v. California, 110 U.S. 516, 538 (1884) (grand jury indictment); see also infra Parts III.B and III.C; Wildenthal, Road to Twining, supra note 4, at Part II.B.

93 These are the Third Amendment freedom from quartering of soldiers and the Eighth Amendment immunities from excessive bail and excessive fines. See supra note 90 . The Court has noted in dicta, however, that it has generally been assumed that the Excessive Bail Clause applies to the states via the Fourteenth Amendment. See Schilb v. Kuebel, 404 U.S. 357, 365 (1971); see also Wildenthal, Road to Twining, supra note 4, at Part V.

94 These may be numbered as follows: (1) rule against suspension of the writ of habeas corpus, see U.S. CONST. art. I, $\S 9, \mathrm{cl} .2$; (2) right to criminal jury trial, id. art. III, § 2, cl. 3; (3) immunity from liability for treason unless guilty of "levying War against [the United States], or ... adhering to their Enemies, giving them Aid and Comfort," id. $\S 3$, cl. 1 ; (4) immunity from conviction for treason "unless on the Testimony of two Witnesses to the same Overt Act, or on Confession in open Court," id.; (5) immunity from any "Attainder of Treason ... work[ing] Corruption of Blood, or Forfeiture except during the Life of the Person attainted," id. $\S 3$, cl. 2; and (6) immunity from any religious test for federal office, id. art. VI, cl. 3. The original Constitution also guarantees three individual rights against both federal and state violation: (1) immunity from bills of attainder; (2) immunity from ex post facto laws; and (3) rule against grants of nobility. Id. art. I, $\S 9$, cls. 3,8 ; id. $\S 10$, cl. 1 . The amendments provide such dual protection to another eight rights: (1) prohibition of slavery and involuntary servitude, id. amend. XIII, $\$ 1$; (2) right to United States citizenship by birth within United States jurisdiction, $i d$. amend. XIV, $\$ 1$; (3) right of United States citizens to state citizenship by residence within any state, id.; (4) right not to be deprived of "life, liberty, or property, without due process of law," $i d$. amend. V; id. amend. XIV, $\S 1 ;(5)$ right of United States citizens to vote without regard to "race, color, or previous condition of servitude," id. amend. XV, $\S 1$; (6) right of United States citizens to vote without regard to sex, id. amend. XIX, $\S 1$; (7) right of 


\section{THE ENIGMA OF SLAUGHTER-HOUSE}

\section{A. Introduction and 1868-1873 Developments}

Anyone reading the Fourteenth Amendment Privileges and Immunities Clause for the first time, uncluttered by prior notions, would surely experience the epiphany that she had discovered something quite important. Surely those sweeping, majestic words-so redolent of the "thou shalt nots" of the Ten Commandments-played a major role in many great Supreme Court decisions and inspired many an impassioned debate on the boundaries of liberty and power. But as we know, such is not the case. The Due Process and Equal Protection Clauses have seen all the action. ${ }^{96}$ Like a forgotten elder brother of its more famous siblings, the Privileges and Immunities Clause looms mysteriously as the silent partner of Section 1 of the Fourteenth Amendment. The war over incorporation itself has been fought mostly on the terrain of the Due Process Clause. ${ }^{97}$ Its first battlefield, the Privileges and Immunities Clause, has remained eerily undisturbed since the Slaughter-House Cases ${ }^{98}$ were decided in 1873.

The Slaughter-House majority's interpretation of the Privileges and Immunities Clause has long been almost universally viewed as a barren tautology nullifying whatever real meaning it was intended to have..$^{99}$ To be sure, the Court recently employed the Clause in Saenz v. Roe ${ }^{100}$ to strike down a California law

United States citizens to vote in federal elections without regard to "failure to pay any poll tax or other tax," id. amend. XXIV, $\S 1$; and (8) right of United States citizens aged eighteen and older to vote without regard to age, $i d$. amend. XXVI, $\S 1$. Finally, the Constitution guarantees two individual rights against state but not federal violation: (1) immunity from impairment of contracts, id. art. I, $\S 10, \mathrm{cl}$. 1; and (2) right to "equal protection of the laws," id. amend. XIV, $\S 1$. But see Bolling v. Sharpe, 347 U.S. 497, 499-500 (1954) (holding that equal protection guarantee applies in substance to federal government).

95 Some preliminary thoughts on those issues will be offered in the sequel to this article. See Wildenthal, Road to Twining, supra note 4, at Part V.

96 See supra note 3 (quoting Section 1 of Amendment); GUNTHER \& SULLIVAN, supra note 25, at 453-916 (surveying staggeringly vast case law construing Due Process and Equal Protection Clauses).

97 See supra notes 6 and 91.

98 83 U.S. (16 Wall.) 36 (1873).

99 See, e.g., EDWARD S. CORWI, ThE CONSTTIUTION AND What IT MEANS TODAY 46061 (Harold W. Chase \& Craig R. Ducat, eds., 14th ed. 1978) (1920); ELY, supra note 6, at 22; GUNTHER \& SULLIVAN, supra note 25, at 429-30; see also BERGER, GOVERNMENT, supra note 33 , at $45-49$ (criticizing, even from his restrictive perspective on the Clause, majority's even narrower conventionally received constuction); Fairman, supra note 22, at 8-9 (stating that in Slaughter-House, the Clause was "virtually read out of the Constitution"). See generally Aynes, Miller, supra note 41; Curtis, Resurrecting, supra note 41.

100 526 U.S. 489 (1999); see also supra Part I.A. 
disfavoring welfare applicants who recently migrated from out of state. ${ }^{101}$ Four Justices made similar use of the Clause in joining the Court's unanimous 1941 decision striking down California's attempt to close its borders altogether to indigent migrants. ${ }^{102}$ This use of the Clause was forecast explicitly by dicta in Slaughter-House itself, where the Court observed that one privilege "conferred by the very article under consideration ... is that a citizen of the United States can, of his own volition, become a citizen of any State of the Union by a bona fide residence therein, with the same rights as other citizens of that State."103 As that very language indicates, however, and as Saenz reflects, this right of free and equal interstate migration is ultimately and more specifically rooted in the Citizenship Clause. ${ }^{104}$ It cannot plausibly be thought to exhaust the scope of the Privileges and Immunities Clause, though one might get that impression from the sparse case law on the latter. ${ }^{105}$

Slaughter-House was a most ill-suited occasion to address the incorporation issue. The decision did not turn on whether the Fourteenth Amendment incorporated any of the specific privileges or immunities set forth in the Bill of Rights. The controversy arose from the protest of the butchers of New Orleans against a city monopoly on slaughtering facilities enacted, purportedly for health and safety reasons, by the Louisiana legislature. ${ }^{106}$ As Professor Kaczorowski has

101 Saenz, 526 U.S. at 497-511.

102 Edwards v. California, 314 U.S. 160, 177-81 (1941) (Douglas, J., joined by Black and Murphy, JJ., concurring); id. at 181-86 (Jackson, J., concurring).

10383 U.S. (16 Wall.) at 80.

104 "All persons born or naturalized in the United States, and subject to the jurisdiction thereof, are citizens of the United States and of the State wherein they reside." U.S. CONST. amend. XIV, § 1; see also Saenz, 526 U.S. 503, 510-11 (quoting and relying on Citizenship Clause); William Cohen, Discrimination Against New State Citizens: An Update, 11 CoNsT. COMM. 73 (1994), quoted with approval in Saenz, 526 U.S. at 507 n.20; William Cohen, Equal Treatment for Newcomers: The Core Meaning of National and State Citizenship, 1 CoNST. COMM. 9 (1984).

105 The interstate equality aspect of the Clause was also employed in Colgate v. Harvey, 296 U.S. 404 (1935), which struck down a state law taxing out-of-state investment income but exempting interest earned on certain in-state investments. See id. at 426-33. But see Madden v. Kentucky, 309 U.S. 83, 90-93 (1940) (overruling Colgate). The incorporation issue did not arise in either case.

106 See Slaughter-House, 83 U.S. (16 Wall.) at 38-44, 57-60; KACZOROWSKI, POLITICS, supra note 88 , at $143-49$. The slaughter-house law embodied both the typical virtues and notorious faults of Southern Reconstructionism. While genuine and progressive concerns over health and sanitation played a role in the legislation, "the process ... was riddled with blatant corruption, bribery, graft and economic self-interest." KACZOROWSKI, POLIICS, supra note 88, at 143-44; see also Curtis, Resurrecting, supra note 41, at 71. One of the ironies of the dispute was that 
noted, the factual setting allowed the Court to decide ideologically explosive issues in a deceptively mundane business context. ${ }^{107}$ The butchers claimed that their right to pursue their livelihood, their "right of free labor," in Justice Field's euphonious phrase, 108 had been unconstitutionally abridged. Justice Field described this as "one of the most sacred and imprescriptible rights of man,"109 but it does not appear anywhere in the Bill of Rights.

The Slaughter-House Court did not write on a blank slate. Some lower federal courts had already held that Bill of Rights guarantees were now, by virtue of the Fourteenth Amendment, applicable to the states. Most intriguingly, newly appointed U.S. Circuit Judge William B. Woods of Alabama held in two 1871 cases-ten years before his elevation to the Supreme Court-that the Privileges and Immunities Clause incorporated the entire Bill of Rights, most notably the First Amendment freedoms of speech and assembly. ${ }^{110}$ Justice Bradley, himself then recently appointed to the Supreme Court, expressed his support for incorporation in private correspondence with Judge Woods regarding the first of those cases, ${ }^{111}$ consistently with views he would later express, as we shall see, in Slaughter-House itself. ${ }^{112}$

Democratic Conservatives and others who opposed the ... monopoly created by a comupt Republican controlled Louisiana legislature embraced the nationalist theory of civil rights enforcement authority associated with the Republican Party, while Republicans and others who wanted the slaughterhouse [monopoly] invoked a more states rights oriented theory of civil rights enforcement authority associated with Democratic Conservatives.

KACZOROWSKI, POLITCS, supra note 88, at 146.

107 See KACZOROWSKI, POLIIICS, supra note 88, at 143. As Kaczorowski observed: "The litigants were white butchers and a ... corporation rather than blacks and Klansmen." Id.

108 Slaughter-House, 83 U.S. (16 Wall.) at 110 (Field, J., dissenting).

109 Id.

110 See United States v. Hall, 26 F. Cas. 79, 81-82 (C.C.S.D. Ala. 1871); United States v. Mall, 26 F. Cas. 1147 (C.C.S.D. Ala. 1871); CURTIS, No STATE, supra note 22, at 171-72; KACZOROWSK, POLIICS, supra note 88, at 14-17, 23 n.25; Amar, supra note 22, at 1256; Aynes, Bingham, supra note 54, at 97-98. But see Wildenthal, Road to Twining, supra note 4, at Part II.C (discussing Justice Woods's apparent abandonment of incorporation on Supreme Court). Judge Woods was joined in Hall by District Judge Richard Busteed. See Hall, 26 F. Cas. at 79; KACZOROWSKI, POLITCS, supra note 88, at 10,67-68.

111 See KACZOROWSKI, PolmicS, supra note 88, at 14-16. As Kaczorowski noted, "[Judge Woods's] opinion closely followed the reasoning of Justice Bradley. Indeed, portions of it were verbatim copies of Justice Bradley's letter." Id. at 16.

112 Slaughter-House was decided on appeal from the Louisiana Supreme Court, which upheld the monopoly in April 1870. See Slaughter-House, 83 U.S. (16 Wall.) at 44; KACZOROWSKI, POLITICS, supra note 88, at 144-45. In June 1870, before the U.S. Supreme Court accepted the appeal, the butchers sought an injunction from the U.S. Circuit Court for Louisiana. Justice Bradley, sitting as Circuit Justice and joined by Judge Woods, wrote an opinion granting partial relief to the butchers and embracing a broad, nationalistic view of the 
Some judges and prosecutors involved in federal prosecutions of the $\mathrm{Ku}$ Klux Klan between 1868 and 1873 also took a broad view of the Amendment as incorporating Bill of Rights guarantees. ${ }^{113}$ During congressional debates over civil rights legislation in 1871-72, the incorporationist theory of the Privileges and Immunities Clause was arguably "the prevailing view on the subject," 114 among both Republicans and Democrats. 115 The Ohio Supreme Court, in an 1872 decision upholding segregated public education, suggested an incorporationist understanding of the Clause. ${ }^{116}$ On the other hand, at least one

Fourteenth Amendment (though he did not there address the issue of incorporation). See LiveStock Dealers' and Butchers' Ass'n v. Crescent City Live-Stock Landing and Slaughter-House Co., 15 F. Cas. 649 (C.C.D. La. 1870); KACZOROWSKI, PoLmICS, supra note 88, at 145-46.

113 See CURTIS, No STATE, supra note 22, at 172; HALBROOK, supra note 52, at 135-45; KACZOROWSKI, POLIICS, supra note 88, at 20, 122-34; LOU FALKNER WILLIAMS, THE GREAT SOUTH CAROLINA KU KLUX KLAN TRIALS, 1871-1872, at 60-76 (1996). Federal prosecutors and judges were engaged at the time in enforcing the Enforcement Act of 1870, 16 Stat. 140 (1870), and the Enforcement (Ku Klux Klan) Act of 1871, 17 Stat. 13 (1871). These laws were designed to curb Klan terrorism aimed at the freed slaves; of more troubling and pressing concern than incorporation were the issues they raised regarding federal authority to reach private abuses not involving state action. See KACZOROWSKI, POLITCS, supra note 88, at 13$14,53-54,117-34,199-217$. One federal prosecutor joining in this enforcement effort was John A. Minnis, U.S. Attorney for the Northern District of Alabama. See id. at 118. Minnis provided critical assistance in battling the Klan to Fayette County Sheriff Marion Francis Treadaway, for which the sheriff's family was so grateful that his daughter named his grandson Frank Minnis Johnson in his honor. Johnson in turn named his son Frank Minis Johnson, Jr. (the extra " $n$ " being accidentally dropped on the birth certificate). The younger Johnson went on to serve as U.S. Attomey for the Northern District of Alabama, eighty years after Minnis held that post, and then as a federal judge, for whom I clerked. See supra note *; BASS, supra note *, at 5-10, 80-94; SIKORA, supra note *, at 71-77; TRELEASE, supra note *, at 252-53, 267-69, 306, 410 .

114 Crosskey, supra note 61, at 100 (discussing House debate on Enforcement (Ku Klux Klan) Act of 1871, 17 Stat. 13 (1871)); see also Maltz, Concept, supra note 52, at 525-27 (discussing 1872 Senate debate on bill that later became Civil Rights Act of 1875,18 Stat. 335 (1875)).

115 There was deep division over the scope of Congress's enforcement power, see U.S. CONST. amend. XIV, $\S 5$, especially whether it went beyond state action to reach private violations of rights, but even those taking a narrow view on that issue appeared to agree with, or at least not dispute, Representative Bingham's view, which he expressly reiterated in 1871, that the Privileges and Immunities Clause encompassed the entire Bill of Rights. See Crosskey, supra note 61, at 88-100; Malt, Concept, supra note 52, at 525-27; see also CuRTIS, No STATE, supra note 22, at 161-66; HALBROOK, supra note 52, at 119-34, 145-49; Avins, supra note 62 , at 24-25.

116 See Ohio ex rel. Garnes v. McCann, 21 Ohio St. 198, 209-10 (1872) ("[T]he clause, ... taken in connection with other provisions of the amendment, and of the constitution of which it forms a part, affords strong reasons for believing that it includes only such privileges or immunities as are derived from, or recognized by, the constitution of the United States."). 
lower federal court and one state court appeared to reject incorporation during this time. ${ }^{117}$

Professor Fairman, thinking he had refuted any incorporationist understanding of the Fourteenth Amendment in the congressional and ratification debates, went on to contend that "the contemporary Supreme Court knew nothing of [the theory] either."118 Fairman's primary evidence was the Court's 1869 decision in Twitchell v. Pennsylvania, ${ }^{119}$ which, in cursory reliance on Barron $v$. Baltimore ${ }^{120}$ and its progeny, rejected jurisdiction over a capital defendant's claim that his state-court indictment violated the Fifth Amendment's Due Process Clause and the Sixth Amendment right to be properly informed of a criminal accusation. ${ }^{121}$ The Fourteenth Amendment, ratified less than a year before, was never raised, and thus, quite properly in accord with canons of judicial restraint, was not addressed by the Court. ${ }^{122}$

117 See United States v. Crosby, 25 F. Cas. 701, 704 (C.C.D.S.C. 1871); Rowan v. State, 30 Wis. 129, 148-50 (1872); Fairman, supra note 22, at 110-11. In Crosby, the court stated that the Fourth Amendment right to be secure against unreasonable searches and seizures was "a mere restriction upon the United States itself," which might be read merely to refer to a stateaction problem in the indictment, which alleged a conspiracy by private citizens to violate the right. $25 \mathrm{~F}$. Cas. at 704 . The court did not discuss whether the right might be a "restriction upon" a state, though it did offer the puzzling non sequitur that because the right pre-dated the Constitution in the common law, it was therefore not "secured by the constitution." See id. But why could a right not both have "existed ... at common law" and be "secured by the constitution"? Cf. id.; KACZOROWSKI, POLIICS, supra note 88, at 128; WILLIAMS, supra note 113 , at 71-73.

118 Fairman, supra note 22, at 132.

11974 U.S. (7 Wall.) 321 (1869); Fairman, supra note 22, at 132-33; see also BERGER, GOVERNMENT, supra note 33, at 153 \& n.84; Felix Frankfurter, Memorandum on "Incorporation" of the Bill of Rights into the Due Process Clause of the Fourteenth Amendment, 78 HARV. L. REV. 746, 749-50 (1965).

12032 U.S. (7 Pet.) 243 (1833).

121 See Twitchell, 74 U.S. (7 Wall.) at 325-27.

122 See id. at 321-27. It is hombook law-and goes to the very essence of judicial power and restraint in the American tradition, including our courts' traditional aversion to advisory opinions - that a court generally will not, and should not, address an issue abandoned or never raised before it, see Phillips v. Wash. Legal Found., 524 U.S. 156, 164 n.4 (1998) (noting that "it would be improper for us sua sponte to raise and address" questions not raised by parties before the Court); see also, e.g., Posters 'N' Things, Ltd. v. United States, 511 U.S. 513, 527 (1994); Helicopteros Nacionales de Colombia, S.A. v. Hall, 466 U.S. 408, 415 n.10 (1984); Russell v. United States, 369 U.S. 749, 754 n.7 (1962); Newsom, supra note 22, at 726-27 n.410, with rare exceptions such as a court's own lack of subject-matter jurisdiction, see, e.g., Louisville \& Nashville R.R. Co. v. Mottley, 211 U.S. 149, 152 (1908). As the Court stated in Yalaus v. United States, 321 U.S. 414, 444 (1944), "[n]o procedural principle is more familiar ... than that a constitutional right may be forfeited in criminal as well as civil cases by the failure to make timely assertion of the right." 
Professor Fairman argued that had the incorporation issue occurred to the Court, it "would have suggested the question and heard argument before disposing of the petition of one sentenced to death."123 But as Professor Amar has noted, there was no "uncertainty" that the Fourteenth Amendment guaranteed "due process" in a state trial, and yet the Court refused to consider the due process claim simply because counsel had invoked, not the Fourteenth Amendment's Due Process Clause, but that of the Fifth. Thus, Twitchell "proves too much - and therefore nothing at all."124

123 Fairman, supra note 22, at 133; see also Dripps, supra note 64, at $1579-82$ (likewise overreading Twitchell's significance); Mendelson, supra note 62, at 721 (same). It appears that no written briefs were filed, though the Court did hear oral argument by the defendant's attomey. See Dripps, supra note, at 1579.

124 Amar, supra note 22, at 1255. As Amar suggested, all Twitchell proves is that the Court, when it wants to, can strictly confine itself to properly raised issues. See id. at 1259 n.286. That the Court has not always done so is reflected in Walker v. Sauvinet, 92 U.S. 90 (1876) and United States v. Cruikshank, 92 U.S. 542 (1876), discussed in Parts III.B and III.C. It appears doubtful in any event whether the defendant in Twitchell could plausibly have shown a violation of due process or the right to be properly informed of the accusation, based on the sparse facts given, which may further explain the ease with which the Court unanimously disposed of the case. See Twitchell, 74 U.S. (7 Wall.) at 321-22. Professor Dripps, viewing Twitchell as seriously undercutting the incorporation theory, see Dripps, supra note 64, at 1579-82, criticized Amar for "explain[ing] Twitchell as judicial incompetence, pure and simple." Id. at 1580. The defendant's lawyer may well have slipped up (hardly an earthshaking proposition), but it was not "incompetent," but rather reflected utmost propriety, for the Court not to address a claim not raised before it (a rather basic principle of the American adversary legal system). See supra note 122. In any event, Dripps himself undercut the importance he claimed for Twitchell by correctly pointing out that the defendant's due process claim was simply "weak" in any event. See Dripps, supra note 64, at 1581. Dripps asserted that "Twitchell proves that ... a unanimous Supreme Court thought Barron was good law immediately after the adoption of the Fourteenth Amendment." Id. Barron was, of course, good law in 1869 and remains so today, in the sense that the Fifth and Sixth Amendments do not, of their own force, apply to the states. That was the only issue Twitchell addressed. To borrow Dripps's words, it seems "not a very convincing account," id. at 1580, to treat as an important refutation of incorporation the Court's mere silence in a case where the Fourteenth Amendment itself was not even raised and the underlying Bill of Rights claim that might have been raised via the Fourteenth Amendment lacked substantial merit. Cf. Newsom, supra note 22, at 721-23 (discussing Twitchell). Likewise devoid of significance for the incorporation issue, Professor Fairman notwithstanding, $c f$. Fairman, supra note 22, at 133-34, is Justices of the Supreme Court of New York v. Murray, 76 U.S. (9 Wall.) 274 (1870), which held that the Seventh Amendment, of its own force, prohibits reexamination in any federal court (except in accordance with common law rules) of any fact tried by a state-court jury. The Court briefly acknowledged in dicta the established rule that the Seventh Amendment, of its own force, does not govern state courts, citing Barron and Twitchell, but noted that this had "no pertinent... application to the question at hand," which concerned the powers of a federal court. Id. at 278. The Fourteenth Amendment was neither raised nor relevant. 


\section{B. Article IV and the Equal-Rights-Only Theory}

In Slaughter-House, unlike Twitchell, the Fourteenth Amendment was invoked. But, as noted, Slaughter-House did not directly implicate the Bill of Rights, nor did it really involve any claim of absolute abridgment of any substantive rights, of "free labor" or otherwise. Rather, the decision concerned only the allegedly unequal treatment of the butchers as compared to the disputed monopoly. As the majority correctly noted,

it is not true that [the Louisiana law] deprives the butchers of the right to exercise their trade....

$\ldots$

... On the contrary, the [monopoly] is required ... to permit any person who wishes to do so, to slaughter in [its] houses; and [it is] bound to make ample provision for the convenience of all the slaughtering for the entire city. The butcher, then, is still permitted to slaughter, to prepare, and to sell his own meats; but he is required to slaughter at a specified place and to pay a reasonable compensation for the use of the accommodations furnished him at that place. 125

This excerpt helps to explain why both the majority opinion and Justice Field's dissent focused heavily on the issue of equal rights ${ }^{126}$ and why they focused little, if at all, on whether the Fourteenth Amendment substantively incorporates the Bill of Rights. What has been said so far should also be enough to suggest that the modern Supreme Court, applying current Fourteenth Amendment doctrine, would surely - and properly so-have little difficulty upholding a law like the one challenged in Slaughter-House as a classic example of an economic regulation subject to the most deferential scrutiny. ${ }^{127}$

\section{Slaughter-House, 83 U.S. (16 Wall.) at 60-61.}

${ }^{126}$ See id. at 62-66 (discussing historical acceptance of special and exclusive business privileges analogous to challenged law); id. at 81 (rejecting butchers' challenge under equal protection Clause); id. at 84-89 (Field, J., dissenting) (excoriating unjust inequality of monopolies); id. at 89-94, 97-101 (Field, J., dissenting) (relying on Thirteenth and Fourteenth Amendments and Civil Rights Act of 1866 to assert "right to pursue a lawful employment in a lawful manner, without other restraint than such as equally affects all persons"); id. at 106-09 (Field, J., dissenting) (discussing several cases said to support "recognition of the equality of right among citizens in the pursuit of the ordinary avocations of life, and ... that all grants of exclusive privileges, in contravention of this equality, are against common right, and void"); $i d$. at 109-11 (Field, J., dissenting) (concluding with repeated references to "equality of right" allegedly violated by challenged law).

127 See, e.g., New Orleans v. Dukes, 427 U.S. 297 (1976) (upholding special economic privileges of certain New Orleans pushcart vendors under deferential standard of review); see also GUNTHER \& SULLIVAN, supra note 25, at 474-86, 635-62; Curtis, Resurrecting, supra note 41, at 105 (in article generally criticizing Slaughter-House majority for unduly narrow reading of Amendment, concluding that majority nevertheless "was right in seeking an 
The equal rights focus of Slaughter-House, though merely dictated by the facts, has contributed to an alternative reading of the Fourteenth Amendment Privileges and Immunities Clause that has garnered some support over the years: that the Clause merely guarantees equal enjoyment of certain rights, not substantive protection for any absolute class of rights. ${ }^{128}$ Because of the importance of this issue to understanding Slaughter-House and the proper bearing of the Clause on incorporation, it is worth discussing in some detail.

The equal-rights-only view of the Fourteenth Amendment Clause draws heavily on its roots in the Privileges and Immunities Clause in Article IV of the original Constitution. ${ }^{129}$ The latter has long been construed as merely a type of equal rights Clause. The Supreme Court settled on that interpretation by 1869 in a unanimous opinion by Justice Field, which declared that the Article IV Clause "place[s] the citizens of each State upon the same footing with citizens of other States, so far as the advantages resulting from citizenship in those States are concerned. It relieves them from the disabilities of alienage in other States... [and] inhibits discriminating legislation against them by other States ...."130 Or, as the Court more recently phrased it, the Article IV Clause guarantees "to a citizen of State A who ventures into State B the same privileges which the citizens of State B enjoy."131

Justice Field's Slaughter-House dissent discussed how the Fourteenth Amendment Clause differs from its Article IV predecessor, taking into account his own 1869 opinion. That case held that corporations are not "citizens" for purposes of the Article IV Clause. 132 "The whole purport of the [1869] decision

interpretation of the Privileges or Immunities Clause that did not risk total destruction of state power" and "was right in not removing subjects from the democratic process because they fall loosely under the rubric of economic liberty").

128 See, e.g., BERGER, GOVERNMENT, supra note 33, at 20-51; NELSON, supra note 88, at 115-23, 155-64; Harrison, supra note 41; see also supra note 64. Professor Nelson, while arguing that "[u]nderstanding section one [of the Amendment] as an instrument for the equal rather than absolute protection of rights resolves the contradiction in the evidence that has so puzzled historians," concluded that the historical evidence regarding the original understanding cannot resolve "whether section one was intended to be simply an equality provision or a provision protecting absolute rights as well." NELSON, supra note 88, at 118, 123.

129 "The Citizens of each State shall be entitled to all Privileges and Immunities of Citizens in the several States." U.S. CONST. art. IV, § 2, cl. 1.

130 Paul v. Virginia, 75 U.S. (8 Wall.) 168, 180 (1869).

131 Toomer v. Witsell, 334 U.S. 385, 395 (1948); see also, e.g., Sup. Ct. of N.H. v. Piper, 470 U.S. 274 (1985); United Bldg. \& Constr. Trades Council v. Camden, 465 U.S. 208 (1984).

132 See Paul, 75 U.S. (8 Wall.) at 180-82. This aspect of Paul remains good law today, even though its logic was soon undermined by the Court's treatment of corporations as "persons" under the Due Process and Equal Protection Clauses of the Fourteenth Amendment. See Santa Clara County v. S. Pac. R.R. Co., 18 F. 385, 402-07 (C.C.D. Cal. 1883) (Field, Cir. J.), aff'd, 118 U.S. 394 (1886). Professor Julian Eule demonstrated that no basis remains 
was, that citizens of one State do not carry with them into other States any special privileges or immunities, conferred by the laws of their own States, of a corporate or other character."133 But, Field pointed out:

That decision has no pertinency to the questions involved in this case. The common privileges and immunities which of right belong to all citizens, stand on a very different footing. These the citizens of each State do carry with them into other States and are secured by the [Fourteenth Amendment] clause in question, in their enjoyment upon terms of equality with citizens of the latter States. ...

What the [Article IV] clause ... did for the protection of the citizens of one State against hostile and discriminating legislation of other States, the fourteenth amendment does for the protection of every citizen of the United States against hostile and discriminating legislation against him in favor of others, whether they reside in the same or in different States. If under the [Article IV Clause] equality of privileges and immunities is secured between citizens of different States, under the fourteenth amendment the same equality is secured between citizens of the United States. ${ }^{134}$

It is easy to see how this language contributes to the equal-rights-only reading some have placed on Field's entire opinion, ${ }^{135}$ though such a reading must ultimately be rejected for reasons discussed below.

The equal rights interpretation of the Article IV Clause has been further limited by the long-established rule that it guarantees equal enjoyment only of those rights deemed "fundamental."136 As a limiting gloss on the egalitarian reading of the Article IV Clause, this "fundamental rights" focus has been severely criticized by various Justices and scholars. ${ }^{137}$ Further complicating matters is that an alternative theory of the Article IV Clause enjoyed some

today for the Court to adhere to this anachronistic limitation with regard to the Article IV Clause (nor, by extension, I would argue, with regard to the Fourteenth Amendment Clause). Julian N. Eule, Laying the Dormant Commerce Clause to Rest, 91 YALE L.J. 425, 452 (1982) (noting that corporations have long been viewed as "citizens" for diversity jurisdiction purposes under Article III, and that cases applying Equal Protection Clause to discrimination against outof-state corporations had "stripped Justice Field's position [in Paul] of every one of its legal underpinnings'); see also Bryan H. Wildenthal, Note, State Parochialism, the Right to Travel, and the Privileges and Immunities Clause of Article IV, 41 STAN. L. REV. 1557, 1568 \& n.78 (1989) [hereinafter Wildenthal, Note] (discussing Eule's views and collecting additional scholarly support for treating corporations as "citizens" for purposes of Article IV Clause).

133 Slaughter-House, 83 U.S. (16 Wall.) at 100 (Field, J., dissenting).

${ }^{134}$ Id. at 100-01 (Field, J., dissenting).

135 See, e.g., NELSON, supra note 88, at 156-58; Harrison, supra note 41, at 1466-68.

136 See, e.g., Baldwin v. Mont. Fish and Game Comm'n, 436 U.S. 371, 388 (1978).

137 See, e.g., id. at 395-98 (Brennan, J., joined by White and Marshall, JJ., dissenting); David S. Bogen, The Privileges and Immunities Clause of Article IV, 37 CASE W. RES. L. REV. 794, 844 (1987); Jonathan D. Varat, State "Citizenship" and Interstate Equality, 48 U. CHI. L. REv. 487, 514-15 (1981); Wildenthal, Note, supra note 132, at 1562-64, $1591-93$. 
currency among Civil War-Era Republicans, notably Representative Bingham. This theory was that the Article IV Clause did not merely guarantee interstate equality but also provided substantive protection for "fundamental" rights, including but not limited to those set forth in the Bill of Rights. ${ }^{138}$

The "fundamental rights" spin on the Article IV Clause appears to be rooted in Justice Bushrod Washington's famous 1825 circuit court opinion in Corfield $v$. Coryell. ${ }^{139}$ Corfield upheld a New Jersey law prohibiting out-of-state citizens from gathering oysters in New Jersey waters, ${ }^{140}$ on the theory that they were the common property of New Jersey citizens. ${ }^{141}$ More widely cited than the holding have been Washington's dicta listing various "privileges and immunities which are, in their nature, fundamental."142 Nothing in Corfield suggests any reason to conclude that Washington intended any departure from an interstate equality theory of the Article IV Clause. His holding and express language indicated his intent was merely to "confin[e]" the scope of the Clause's reach in that regard. ${ }^{143}$ Rightly or wrongly, however, Corfield has sometimes been read to support the substantive theory of the Clause. ${ }^{144}$

Regardless of which view of the Article IV Clause is correct, or which held sway when the Fourteenth Amendment was proposed, it is common ground that the language of the Fourteenth Amendment Clause was adapted from Article

138 See CURTIS, No STATE, supra note 22, at 47-48, 61, 114-15, 149-51; Amar, supra note 22, at 1229; Crosskey, supra note 61, at 11-16.

1396 F. Cas. 546 (C.C.E.D. Pa. 1825) (Washington, Cir. J.).

140 See id. at 550-53.

141 See id. at 552; see also Baldwin, 436 U.S. at 384, 388 (treating elk and other wildlife as common property of Montana citizens); McCready v. Virginia, 94 U.S. 391, 395-96 (1877) (treating oysters as common property of Virginia citizens).

142 See Corfield, 6 F. Cas. at 551-52.

143 See id. at 551; see also BERGER, FOURTEENTH, supra note 60, at 34-36; BERGER, GOVERNMENT, supra note 33, at 31-34. As Berger noted, Washington plainly erred by including "the elective franchise" in his list of "fundamental rights" protected by the Article IV Clause, see Corfield, 6F. Cas. at 552, because that would lead to the absurd result of temporary visitors to other states enjoying the right to vote on an equal basis with resident citizens. See BERGER, GOVERNMENT, supra note 33, at 32; see also Minor v. Happersett, 88 U.S. (21 Wall.) 162,174 (1875) (rejecting such a reading of the Clause).

144 See, e.g., Crosskey, supra note 61, at 14-16. I would now retract my youthful suggestion, see Wildenthal, Note, supra note 132, at 1569, that Justice Washington in Corfield supported substantive protection of "fundamental" rights via the Article IV Clause; I did not approve of such a theory then (nor do I now), and I no longer believe that Justice Washington embraced such a theory. I remain of the view that the Corfield-inspired fundamental-rights limitation on the Article IV Clause (construed in its proper interstate equality sense) is misguided. See supra note 137. 
IV. 145 There is no reason to suppose that the words "privileges or immunities" have any broader meaning in the Fourteenth Amendment than in Article IV. They might, indeed, have a narrower meaning in the Fourteenth Amendment, in light of their modification by the phrase, "of citizens of the United States."146 But in any event, this does not resolve the proper construction of the Fourteenth Amendment Clause. Even if the words "privileges or immunities" have the same meaning in both Clauses, the full text of the Fourteenth Amendment Clause renders the equal-rights-only interpretation of the latter Clause untenable.

The Fourteenth Amendment Clause, unlike its Article IV counterpart, is simply not phrased as a relativistic guarantee of equal rights, but rather flatly declares that "[n]o state shall make or enforce any law which shall abridge" a certain class of rights. ${ }^{147}$ Furthermore, the equal-rights-only reading of the Privileges and Immunities Clause would render it utterly redundant to the Equal Protection Clause. The latter shows the framers of the Amendment knew perfectly well how to express the concept of an equal rights guarantee. 148 The

145 See, e.g., Saenz v. Roe, 526 U.S. 489, 502 n.15 (1999) (citing CONG. GLOBE, 39th Cong., 1st Sess. 1033-34 (1866) (Rep. Bingham)).

146 U.S. CONST. amend. XIV, § 1; see also infra Parts II.C-E. One respect in which Fourteenth Amendment privileges and immunities might arguably be construed more broadly than Article IV privileges and immunities is that the former would seem to include the rights of United States citizens to vote free of various forms of discrimination, as guaranteed by the Fifteenth, Nineteenth, Twenty-Fourth, and Twenty-Sixth Amendments, see supra note 94, whereas the right to vote seems clearly not covered by Article IV, see supra note 143. It's a moot point, however, since all the cited amendments apply expressly to the states as well as the federal government in any event. See supra note 94. Thus, no incorporation issue arises.

${ }^{147}$ U.S. CONST. amend. XIV, $\$ 1$ (emphases added). Justice Bradley, in his 1870 Slaughter-House circuit court opinion, see supra note 112, noted, "It was very ably contended... that the ... fourteenth amendment was intended only to secure to all citizens equal capacities before the law. That was at first our view of it. But it does not so read." LiveStock Dealers' and Butchers' Ass'n v. Crescent City Live-Stock Landing and Slaughter-House Co., 15 F. Cas. 649, 654 (C.C.D. La. 1870) (Bradley, Cir. J., joined by Woods, J.). "[T] fourteenth amendment ... not merely requires equality of privileges; but it demands that the privileges and immunities of all citizens shall be absolutely unabridged, unimpaired." Id. at 652; see also, e.g., Douglas G. Smith, Natural Law, Article IV, and Section One of the Fourteenth Amendment, 47 AM. U. L. REV. 351, 405-06 (1997) [hereinafter Smith, Natural Law]; Smith, Reconstruction or Reaffirmation?, supra note 63, at 192-94.

148 As Dean Ely has noted, "the slightest attention to language will indicate that it is the Equal Protection Clause that follows the... equality strategy, while the Privileges and Immunities Clause proceeds by purporting to extend to everyone a set of entitlements." ELY, supra note 6, at 24; see also CURTIS, No STATE, supra note 22, at 119 (noting textual impossibility of equal-rights-only reading of Privileges and Immunities Clause); Amar, supra note 22 , at $1243-46$ (rejecting equal-rights-only reading as implausible and contradicted by legislative history). Professor Berger conceded in 1989 the "tautology" created by his equalrights-only reading of the Privileges and Immunities Clause, commenting that "[a]though I have read the ... clauses countless times, I... have overlooked what now seems to me the 
Privileges and Immunities Clause cannot be so limited without doing violence to plain language. The force of this conclusion is confirmed by the contemporary understanding of Representative Bingham, Senator Howard, and many of their Republican contemporaries that the Amendment would provide an absolute floor of protection for substantive liberties, ${ }^{149}$ most especially freedom of speech. ${ }^{150}$

It is likewise unpersuasive to view Justice Field in Slaughter-House as embracing the view that the Fourteenth Amendment Clause is no more than a guarantee of equal enjoyment of fundamental rights. He certainly believed it guaranteed at least that much, as the passage from his dissent quoted above reflects, and he found that sufficient to support his condemnation of the disputed monopoly. ${ }^{151}$ Equal enjoyment of the rights covered by the Clause is certainly assured, since any unequal abridgment would be no less an abridgment. Again, it bears repeating, the facts of Slaughter-House drove the incessant emphasis on equal rights and the allegedly unjust inequality of the Louisiana law. But Field's argument as to why the monopoly violated the Clause betrayed his underlying vision, consistent with the plain text discussed above, that it provided substantive protection for certain absolute rights. "The privileges and immunities of citizens of the United States," he declared, are "secured against abridgment in any form by any State. ... All monopolies ... are an invasion of these privileges, for they

duplication of 'abridged' by 'equal protection.' This ... calls for further exploration." BERGER, FOURTEENTH, supra note 60 , at 124 . Or, one might respectfully suggest, reconsideration. In Berger's revision of his 1977 book, however, published eight years after his concession just noted, he made no mention of this problem, instead simply reiterating his view that the Privileges and Immunities Clause is identical in scope to the Civil Rights Act of 1866. See BERGER, GOVERNMENT 1997, supra note 62, at 44-56; see also supra note 64.

149 See CURTIS, No STATE, supra note 22, at 119-20; Amar, supra note 22, at 1218-54. But see generally Harrison, supra note 41 (arguing that the Amendment provides equalitybased not substantive protection). Professor Curtis has provided the most thorough and definitive refutation of the equal-rights-only theory. See Curtis, Resurrecting, supra note 41, at 44-65.

${ }^{150}$ See Curtis, Resurrecting, supra note 41, at 47 (noting that "the primary Republican complaint was not simply about discrimination," but "about the denial of the precious American right to free speech and press"); see also supra note 87.

151 See Slaughter-House, 83 U.S. (16 Wall.) at 101 (Field, J., dissenting):

It will not be pretended that under the [Article IV Clause] any State could create a monopoly in any known trade or manufacture in favor of her own citizens... which would exclude... citizens of other States....

Now, what the [Article IV Clause] does for the protection of citizens of one State against the creation of monopolies in favor of citizens of other States, the fourteenth amendment does for the protection of every citizen of the United States against the creation of any monopoly whatever. 
encroach upon the liberty of citizens to acquire property and pursue happiness ...."152

Professor William Nelson, defending his equal-rights-only view of Justice Field's dissent, argued that Field's supposedly "moderate reading" of the Fourteenth Amendment in Slaughter-House "quickly became the basic doctrine of American constitutional law." 153 Nelson pointed to the 1877 decision in Munn v. Ilinois, ${ }^{154}$ asserting that it thus "took only four years after... SlaughterHouse ... for Justice Field to command a majority on the Court in support of his views."155 But Field dissented in Munn. ${ }^{156}$ The majority in Munn, far more reminiscently of the Slaughter-House majority opinion than of Field's dissent from that decision, upheld the state's power to enforce a reasonable economic regulation of the prices charged by certain types of grain elevators. ${ }^{157}$ Field found that to be an invasion of the substantive "liberty" he thought protected by the Due Process Clause, ${ }^{158}$ notwithstanding that no monopoly was involved. 159

Of course, Professor Nelson was quite right in the sense that Justice Field's views on economic regulations, not those of the Slaughter-House or Munn majorities, did eventually prevail over the next fifty years or so. As Professor Morrison observed, Field, "more than any other one member of the Supreme

152 Id. (Field, J., dissenting) (emphases added). That Field was thinking in terms of substantive liberties is underscored by his open reliance on laissez-faire capitalist economic philosophy. See id. at $110 \mathrm{n} .{ }^{*}$ ("The property which every man has in his own labor ... is the most sacred and inviolable.... [T] 0 hinder him from employing [it]... is a manifest encroachment upon the just liberty both of the workman and of those who might be disposed to employ him.") (quoting ADAM SMTTH, AN INQUIRY INTO THE NATURE AND CAUSES OF THE WEALTH OF NATIONS 151 (1776)). The fact that Justice Bradley, who emphatically rejected an equal-rights-only reading of the Clause in his 1870 Slaughter-House circuit court opinion, see supra notes 112 and 147, joined unreservedly in Field's 1873 Slaughter-House dissent, see Slaughter-House, 83 U.S. (16 Wall.) at 111, still further underscores how implausible it is to impute such a reading to Field.

153 NELSON, supra note 88 , at 164.

15494 U.S. 113 (1877).

155 NELSON, supra note 88, at 165; see also id. at 171-74.

156 On the short end of a 7-2 vote, it might be added. See Munn, 94 U.S. at 136-54 (Field, J., joined by Strong, J., dissenting). Professor Nelson, of course, acknowledged this, but did not take sufficient account of it. See NELSON, supra note 88, at 172-74.

157 See Mron, 94 U.S. at 123-36.

158 The owners protesting the price regulation based their claim primarily on the Due Process Clause and did not invoke the Privileges and Immunities Clause, doubtless because Slaughter-House indicated the latter would be unavailing. See Munn, 94 U.S. at 119-20.

159 See id. at 141-54 (Field, J., dissenting). For Justice Field, the issue was one of pure economic liberty conceived in absolute terms: "whether it is within the competency of a State to fix the compensation which an individual may receive for the use of his own property in his private business, and for his services in connection with it." Id. at 138 . He concluded that the challenged regulation "interfer[ed] with the legitimate profits of that business." Id. at 154. 
Court, was responsible for the establishment of substantive due process."160 But few would describe the line of cases that included Lochner $v$. New York ${ }^{161}$ and ultimately plunged the nation into constitutional crisis as involving any fidelity to a "moderate," equal-rights-only reading of the Fourteenth Amendment.162

In any event, the proposition that the words "privileges or immunities" encompass at least all Bill of Rights guarantees is not dependent on accepting the unorthodox, Civil War-Era Republican view of the Article IV Clause. Even the orthodox interpretation of the Article IV Clause is fully consistent with reading "privileges or immunities" to encompass, at a minimum, all the rights set forth in the Bill of Rights. ${ }^{163}$ To be sure, the Article IV Clause (under the orthodox reading) does not provide any substantive protection for any such rights, but merely guarantees interstate travelers equal enjoyment of such rights, on a par with citizens of any state they may visit, to whatever extent that state may grant such rights to its own citizens. And it is true that Justice Washington in Corfield (if one takes guidance from that case) did not list any specific Bill of Rights guarantees. But he did refer rather sweepingly to rights "enjoyed by the citizens of the several states which compose this Union, from the time of their becoming free, independent, and sovereign," and to "the enjoyment of life and liberty, with the right to acquire and possess property of every kind, and to pursue and obtain happiness and safety."164 He made clear that his list was only a nonexhaustive sample in any event. ${ }^{165}$

${ }^{160}$ Morrison, supra note 6, at 172 n.63; see also JAMES W. ELY, JR., THE CHIEF JUSTICESHIP OF MELVILLE W. FULLER, 1888-1910, at 25-26 (1995) (describing Field as a "prima donna" on the Court who "pioneered a broad reading of the due process clause of the Fourteenth Amendment" and was "the most influential justice during the Gilded Age," whose "property-conscious views gained ascendancy during Fuller's chief justiceship").

161 198 U.S. 45 (1905).

162 See, e.g., W. Coast Hotel Co. v. Parrish, 300 U.S. 379 (1937) (helping resolve constitutional crisis and departing from Lochner doctrine by upholding minimum wage law); Curtis, Resurrecting, supra note 41, at 85-86, 91-93 (discussing connection between Slaughter-House and Lochner). Cf. NELSON, supra note 88, at 197-200 (discussing Lochner and Court's subsequent movement away from Lochner-style activism). The origins and implications of the Lochner doctrine have been the subject of continuing scholarly debate. See, e.g., HOWARD GLLIMAN, THE CONSTITUTION BESIEGED: THE RISE AND DEMISE OF LOCHNER ERA POLICE POWERS JURISPRUDENCE (1993) (taking revisionist view of SlaughterHouse/Lochner-era Court's treatment of economic regulations, finding it rooted more in conceptions of limited governmental police powers than in libertarian conceptions of natural economic rights). But such issues are beyond the scope of this article.

163 See generally Curtis, Historical Linguistics, supra note 62.

164 Corfield v. Coryell, 6 F. Cas. 546, 551-52 (C.C.E.D. Pa. 1825).

$165 \mathrm{He}$ stated that it would "be more tedious than difficult to enumerate" the covered rights, and concluded by suggesting there were "many others which might be mentioned." Id. at 551-52. 
Professor Berger minimized Corfield as "hardly ... expansive," noting that it denied access to a state's oyster beds. ${ }^{166}$ Fair enough, but could a state properly deny out-of-state citizens the right to criminal or civil trial by jury, while granting such rights to its own citizens? Could a state allow freedom of speech to its own residents, yet censor and muzzle the interstate traveler? It hardly seems imaginable that any guarantee mentioned in the Bill of Rights, even those perhaps held in lowest esteem today, ${ }^{167}$ could ever properly have been withheld on such a discriminatory basis, consistent with the Article IV Clause. "Fundamental rights" under the Article IV Clause may not include the rights to hunt elk ${ }^{168}$ or dredge oysters, ${ }^{169}$ but it would be bizarre if they did not include the privileges and immunities enshrined in the Bill of Rights. ${ }^{170}$

Thus, even taking the narrow orthodox reading of the Article IV Clause as a premise, it clearly follows, from the phrasing and history of the Fourteenth Amendment Clause derived from it, that the states are now prohibited from substantively "abridging" this class of "fundamental" rights. That class of rights must surely include, at a minimum, the guarantees set forth in the Bill of Rights, plus whatever other rights might properly be viewed as "fundamental," except to

166 BERGER, FOURTEENTH, supra note 60, at 35-36.

167 See, e.g., Adamson v. Califomia, 332 U.S. 46, 64-65 (1947) (Frankfurter, J., concurring) (noting that "more than half the States" had by then abandoned grand jury); Hurtado v. California, 110 U.S. 516, 538 (1884) (holding that grand jury indictment is not required of states by Fourteenth Amendment). But would even Justice Frankfurter have suggested that a state which still employed the grand jury could dispense with it in charging out-of-state visitors with crimes?

168 See Baldwin v. Mont. Fish and Game Comm'n, 436 U.S. 371, 388 (1978).

169 See McCready v. Virginia, 94 U.S. 391, 395-96 (1877); Corfield, 6 F. Cas. at 551-52.

170 It has been argued that the Article IV Clause, drafted and proposed in 1787, could not possibly have had reference to the privileges and immunities later embodied in the Bill of Rights, drafted and proposed in 1789 and not ratified until 1791. See BERGER, FOURTEENTH, supra note 60, at 92; Fairman, supra note 22, at 62 . But the privileges and immunities of the Bill of Rights were hardly novelties. As is well known, they derived from time-honored principles of British and colonial American law. See generally, e.g., AMAR, BLLL OF RIGHTS, supra note 63, at 3-133; THE COMPLETE BILL OF RIGHTS: THE DRAFTS, DEBATES, SOURCES, AND ORIGINS (Neil H. Cogan ed., 1997). In any event, the Article IV Clause, especially under the orthodox egalitarian reading, is necessarily prospectively open-ended as to what rights are covered. See Crosskey, supra note 61, at 83 (arguing that Article IV Clause "would of course become immediately implemented with all after-created privileges, or immunities ... as soon as any such privileges or immunities were created"); supra note 146 (voting rights created by Fifteenth, Nineteenth, Twenty-Fourth, and Twenty-Sixth Amendments may be viewed as retroactive additions to privileges and immunities protected by Fourteenth Amendment). See generally Curtis, Historical Linguistics, supra note 62 (historical usages support view that words "privileges" and "immunities" were understood to include, and used interchangeably with, rights guaranteed by Bill of Rights). 
the extent the modifying phrase, "of citizens of the United States," might be thought to place a limitation on such privileges and immunities.

\section{Justice Field vs. Justice Miller}

Justice Field certainly did not think the Bill of Rights demarcated any outer limit on the privileges and immunities protected by the Fourteenth Amendment. Field's grandiloquent dissenting opinion in Slaughter-House, joined by Chief Justice Salmon P. Chase and Justices Swayne and Bradley, ${ }^{171}$ is perhaps the best place to start in exploring how broadly the majority viewed that Clause. By understanding what Field hoped to achieve, it becomes clearer what the majority wished to reject.

What Justice Field aimed at was no less than sweeping federal judicial protection for a range of natural, unwritten rights, as against state regulatory power. Though much of his opinion was devoted to expounding the "privileges or immunities" guaranteed by the Fourteenth Amendment, he nowhere defined them by reference to the Bill of Rights, or to any textually specified rights. Indeed, he scomed the very notion of limiting one's vision to textually guaranteed liberties, and specifically excoriated the majority for, as he saw it, doing just that. In a passage that could be the antithesis of Justice Black's positivist credo, Justice Field declaimed:

If [the Fourteenth Amendment] ... only refers, as held by the majority ... to such privileges and immunities as were before its adoption specially designated in the Constitution or necessarily implied as belonging to citizens of the United States, it was a vain and idle enactment, which accomplished nothing, and most unnecessarily excited Congress and the people on its passage. With privileges and immunities thus designated or implied no State could ever have interfered by its laws, and no new constitutional provision was required to inhibit such interference. The supremacy of the Constitution and the laws of the United States always controlled any State legislation of that character. But if the amendment refers to the natural and inalienable rights which belong to all citizens, [it] has a profound significance and consequence. ${ }^{172}$

The foregoing sounds a lot like a condemnation of any approach-like Justice Black's in Adamson v. California ${ }^{173}$ - that would tie the meaning of the Amendment to all, but only, rights specifically set forth elsewhere in the

171 See Slaughter-House, 83 U.S. (16 Wall.) at 83-111 (Field, J., dissenting).

172 Id. at 96 (Field, J., dissenting) (emphasis added).

173332 U.S. 46, 68-92 (1947) (Black, J., dissenting); see also HuGo LAFAYETTE BLACK, A CONSTITUTIONAL FAITH 18-21, 34-42 (1968) (discussing Black's textualist philosophy of constitutional interpretation). 
constitutional text. But if rights "specially designated in the Constitution" were so inadequate, what rights did Justice Field find in the Privileges and Immunities Clause, and how did he define them? Well, he described them no fewer than five separate times as the "common" rights of all American citizens. ${ }^{174}$ The Clause, he said, guarantees to the United States citizen "[t] he fundamental rights, privileges, and immunities which belong to him as a free man and a free citizen." 175

Justice Field finally, it would seem, got down to business by asking: "What, then, are the privileges and immunities which are secured against abridgment by State legislation?"176 Well, they are "those which of right belong to the citizens of all free governments." 177 What privilege was specifically violated by the New Orleans butchers' monopoly? Said Field: "All monopolies in any known trade or manufacture are an invasion of these privileges, for they encroach upon the liberty of citizens to acquire property and pursue happiness, and were held void at common law in the great Case of Monopolies, decided during the reign of Queen Elizabeth."178 The Fourteenth Amendment, he argued, "was intended to give practical effect to the declaration of 1776 of inalienable rights, rights which are the gift of the Creator, which the law does not confer, but only recognizes."179 And so forth.

The key to understanding Justice Field's philosophy is recognizing the frank natural law assumptions under which he operated. Positivists like Justice Black tend to seek some textual benchmark by which to define rights, and find the absence of such definition troubling, if not intolerable. But for Field and his dissenting colleagues, this was quite evidently part of the natural order of things.

It is very interesting, finally, that Justice Field used the words "bill of rights" only once, toward the very end of his dissent: "[G]rants of exclusive privileges ... are opposed to the whole theory of free government, and it requires no aid from any bill of rights to render them void."180 This may be read as an accusation that the majority was relying-unduly restrictively, in Field's view-

174 See Slaughter-House, 83 U.S. (16 Wall.) at 89, 93, 100, 105 (twice) (Field, J., dissenting); see also, e.g., Newsom, supra note 22, at 659-63 (discussing common-law derivation of "common" rights as referenced in plaintiffs' arguments and Field's dissent).

175 Slaughter-House, 83 U.S. (16 Wall.) at 95 (Field, J., dissenting).

176 Id. at 96 (Field, J., dissenting).

${ }^{177}$ Id. at 97 (Field, J., dissenting).

${ }^{178} \mathrm{Id}$. at 101-02 (Field, J., dissenting).

$179 \mathrm{Id}$. at 105 (Field, J., dissenting) (emphasis added).

${ }^{180} \mathrm{Id}$. at 111 (Field, J., dissenting). The words appear at one other place in Field's dissent, but only as part of a quotation of another case, which conveyed the same backhanded sentiment. See id. at 109 (invalidation of monopoly "does not require even the aid which may be derived from [a state] Bill of Rights") (quoting Norwich Gas Light Co. v. Norwich City Gas Co., 25 Conn. 19, 38 (1856)). 
on the Bill of Rights as a referent for the scope of "privileges or immunities." It displayed the natural law advocate's scorn for the idea that textual guarantees are the sole legitimate source of judicially enforceable rights. For Field, the legal vitality of such rights predated and overarched the written Constitution. For him, Slaughter-House could never have turned on incorporation of the Bill of Rights. What divided him from the majority was the philosophical schism between his natural rights approach and what he may have perceived as the textualist nitpicking of the whole issue of incorporation.

Justice Field's dissent is a revealing mirror in which to view Justice Miller's opinion for the Court, joined by Justices Nathan Clifford, David Davis, William Strong, and Ward Hunt. ${ }^{181}$ The Court rejected all the constitutional claims against the monopoly. ${ }^{182}$ The butchers' central claim, as we have seen, was that they had been denied equal enjoyment of the fundamental right of "free labor," in violation of the Privileges and Immunities Clause. This claim could be refuted by demonstrating either that (1) the monopoly at issue did not, in fact, deny them the equal right to pursue their trade, or (2) the right claimed did not, in any event, fall within the scope of "the privileges or immunities of citizens of the United States.'183 Miller set out to demonstrate both propositions. The former, highly factbound issue need not concern us further. ${ }^{184}$ The latter was where all the interesting fireworks took place.

Justice Miller's discussion of privileges and immunities was preceded by a strangely formalistic analysis of the Citizenship Clause. ${ }^{185} \mathrm{He}$ placed heavy stress on the distinction between state and national citizenship, ${ }^{186}$ and relied on that

181 See Slaughter-House, 83 U.S. (16 Wall.) at 57-83.

182 Other than the Privileges and Immunities Clause claim (the only one warranting discussion here), the Court addressed and rejected claims that the monopoly constituted a form of involuntary servitude, see U.S. CONST. amend. XIII, a denial of equal protection of the laws, see U.S. CONST. amend. XIV, $\S 1$, and a deprivation of property without due process of law, see id. See Slaughter-House, 83 U.S. (16 Wall.) at 66, 69, 80-81.

183 U.S. CoNST. amend. XIV, $\S 1$.

184 See Slaughter-House, 83 U.S. (16 Wall.) at 60-66, 80-81.

185 See supra note 104.

186 Indeed, almost comical stress. Justice Miller asserted:

Not only may a man be a citizen of the United States without being a citizen of a State, but an important element is necessary to convert the former into the latter. He must reside within the State to make him a citizen of it, but it is only necessary that he should be bom or naturalized in the United States to be a citizen of the Union.

Slaughter-House, 83 U.S. (16 Wall.) at 74 (emphases added). Such logic has a tail-waggingthe-dog quality, sort of like arguing that having the car key is more important than buying the car; after all, one "must" turn the key to start the car, while one need "only" plunk down $\$ 20$ thousand or so to buy it in the first place. In fact, of course, an individual has no control over where she is born and can obtain naturalization only with difficulty (most assuredly not by 
distinction to define the scope of the "privileges or immunities" protected by the Fourteenth Amendment. He descended into metaphysical contortions in the process. For example, the Amendment's reference to privileges and immunities "of citizens of the United States" was said to make it "a little remarkable" to think that the Privileges and Immunities Clause "was intended as a protection to the citizen of a State against the legislative power of his own State."187

What Justice Miller was groping to explain was a concept of dual citizenship under which every American wears two hats. He was trying to argue, as we will see, that the Clause only limits a state's power with respect to citizens in their federal capacity, asserting rights under the federal Constitution. But it sounds bizarre. After all, against what other citizens would a state most likely exercise authority, than those who happen to reside within its borders, which is precisely how the Amendment defines state citizens? And the plain language of the Clause, providing that "[n]o State shall make or enforce any law ... abridg[ing]"188 certain rights of such citizens, indicates rather unavoidably that it most certainly does protect state citizens, in some fashion, against the legislative power of their own state. The Clause would not serve much purpose otherwise.

The point of Justice Miller's contortions soon became clear. He was terribly anxious to exclude from the category of Fourteenth Amendment "privileges or immunities" the vast conglomeration of natural and common-law rights suggested by such cases as Corfield $v$. Coryell. ${ }^{189}$ Did the Amendment extend federal judicial protection and legislative power to all of this vast range of ordinary or "natural" rights enjoyed by most people in most states as a matter of history, custom, and state constitutional protection? "[W]as it intended to bring within the power of Congress the entire domain of civil rights heretofore belonging exclusively to the States?"190 If so, Miller argued, it would "fetter and

right), whereas under the Fourteenth Amendment that individual, once a United States citizen, is at complete liberty to claim state citizenship whenever and wherever she pleases, by simply moving and relocating at will. The language of the Citizenship Clause and the overwhelming evidence of the original understanding indicate that it was designed to remove any doubt regarding the citizenship of the freed slaves and to render state citizenship an automatic, derivative appendage of national citizenship. Even scholars as far apart in their views of the Amendment as Berger and Kaczorowski seem to have agreed on that much. See KACZOROWSKI, POLITICS, supra note 88, at 17 ("National and state citizenship were considered to be two dimensions of the same status."); $i d$. at 151-52 (criticizing Miller's heavy stress in Slaughter-House on distinction between national and state citizenship); BERGER, GOVERNMENT, supra note 33, at 44-45 (same).

187 Slaughter-House, 83 U.S. (16 Wall.) at 74.

188 U.S. CONST. amend. XIV, § 1.

1896 F. Cas. 546, 551-52 (C.C.E.D. Pa. 1825); see also Slaughter-House, 83 U.S. (16 Wall.) at 75-77 (quoting and discussing Corfield and other cases); Newsom, supra note 22, at 668-74; supra Part II.B.

190 Slaughter-House, 83 U.S. (16 Wall.) at 77. 
degrade the State governments" and "radically chang[e] the whole theory of the relations of the State and Federal governments to each other and of both these governments to the people."191

Of equal concern to Justice Miller was the lack of a judicially manageable referent for the scope of the rights claimed. Accepting such a broad and openended reading of the Clause would give the Court "authority to nullify such [state legislation] as it did not approve as consistent with those rights."192 This strikingly foreshadowed Justice Black's rationale for total incorporation. Allowing the Court to "substitut[e] natural law concepts for the Bill of Rights," Black argued in Adamson, would "license this Court, in considering regulatory legislation, to roam at large in the broad expanses of policy and morals and to trespass, all too freely, on the legislative domain of the States as well as the Federal Government."193 Black noted with satisfaction that the Slaughier-House majority had "flatly rejected" such "natural law arguments." 194 It was fitting in this regard that Black's appointment in 1937 was a linchpin of the judicial revolution that undid the Lochner doctrine spawned, in part, by Justice Field's Slaughter-House dissent. ${ }^{195}$

In any event, Justice Miller concluded that the sweeping natural rights invoked by the butchers and Justice Field were among "those which belong to citizens of the States as such" and were "not by [the Fourteenth Amendment] placed under the special care of the Federal government." 196 He then proceeded, "lest it should be said that no such ... are to be found,"197 to his famously narrow listing of some of the "privileges or immunities" thought to "owe their existence to the Federal government, its National character, its Constitution, or its laws."198 Much of the list deserves the condemnation of Field's dissent-and of most commentators ever since - as a shamelessly redundant catalogue of rights already fully protected by the Supremacy Clause. ${ }^{199}$ For example, Miller solemnly included the right "to demand the care and protection of the Federal government... when on the high seas or within the jurisdiction of a foreign

191 Id. at 78.

192 Id.

193 Adamson v. California, 332 U.S. 46, 90 (1947) (Black, J., dissenting).

${ }^{194}$ Id. at 77 (Black, J., dissenting); see also id. at 81 (noting that Lochner substantive due process doctrine "marked a complete departure from the Slaughter-House philosophy of judicial tolerance of state regulation of business activities").

195 See DUNNE, supra note 34, at 161-73, 191-92.

196 Slaughter-House, 83 U.S. (16 Wall.) at 78.

197 Id. at 79.

198 Id.

${ }^{199}$ See U.S. CoNST. art. VI, cl. 2; Slaughter-House, 83 U.S. (16 Wall.) at 96 (Field, J., dissenting). 
government,"200 without explaining how it would even be possible for a state to intrude on any such privilege. Equally lacking any need for Fourteenth Amendment protection were "[ $t]$ he right to use the navigable waters of the United States"201 and "all rights secured to [United States] citizens by treaties with foreign nations."202 Seemingly trying to run up the score, Miller concluded by tossing in "the rights secured by the thirteenth and fifteenth articles of amendment, and by the other clause[s] of the fourteenth."203

As we have already seen, Justice Field got quite exercised over all this, and not without reason. Before joining Field in throwing up our hands, however, we must not overlook a sentence buried in the middle of the second paragraph of Justice Miller's list: "The right to peaceably assemble and petition for redress of grievances, the privilege of the writ of habeas corpus, are rights of the citizen guaranteed by the Federal Constitution."204 So they are, and they are rights which, under the rule of Barron v. Baltimore, ${ }^{205}$ were not previously applicable to the states. 206 Some scholars have argued that Miller meant such rights only when exercised in connection with a citizen's relationship with the federal government. $^{207}$ It is certainly true, as discussed in Part III.C, that the Court later adopted that narrower reading. But it seems doubtful that was what Miller meant in Slaughter-House, because he had already listed the right

"to come to the seat of [the federal] government to assert any claim ... upon that government, [or] to transact any business he may have with it, [or] to seek its protection .... He has [a] right [to] free access to ... the [federal] sub-treasuries, [the federal] land offices, [. . . ] and [the federal] courts of justice in the several States."208

200 Slaughter-House, 83 U.S. (16 Wall.) at 79 (opinion of the Court).

201 Id.

202 Id.

${ }^{203}$ Id. at 80 . The latter reference was to the Due Process and Equal Protection Clauses, "next to be considered." Id.

204 Id. at 79.

20532 U.S. (7 Pet.) 243 (1833).

206 See U.S. CoNST. amend. I ("Congress shall make no law ... abridging" rights of peaceable assembly and petition); id. art. I, $\S 9$, cl. 2 (in section listing limitations on congressional but not state power, providing that " $[t]$ he privilege of the Writ of Habeas Corpus shall not be suspended, unless when in Cases of Rebellion or Invasion the public Safety may require it").

207 See, e.g., KACZOROWSKI, PoLITICS, supra note 88, at 152; Aynes, Miller, supra note 41 , at 653-55; see also Amar, supra note 22, at 1258 (noting this "conventional reading" of Miller's opinion).

208 Slaughter-House, 83 U.S. (16 Wall.) at 79 (quoting Crandall v. Nevada, 73 U.S. (6 Wall.) 35,44 (1868)) (bracketing, added here, attempts in part to correct for slight, nonmaterial 
Reading Justice Miller's later sentence on assembly, petition, and habeas corpus as referring only to claims upon the federal government would thus render it doubly redundant. ${ }^{209}$ One would also have to explain why Miller, who explicitly enunciated the governmental relationship limitation on most of the other rights he listed, did not include any such limiting language in the sentence under discussion. His reference to "the privilege of the writ of habeas corpus" was drawn verbatim from the original Constitution. 210 As to assembly and petition, he paraphrased the First Amendment almost verbatim, and to the minor extent he departed from it, his paraphrase tends to contradict any notion that he intended to limit such rights to a citizen's relationship with the federal government. Miller referred to "[t]he right to peaceably assemble and petition for redress of grievances," whereas the First Amendment refers to "the right of the people peaceably to assemble, and to petition the Government for a redress of grievances." 211 The "Government" is an obvious reference to the federal government, in accordance with the orthodoxy of Barron. Assuming Miller's dropping of the word has any significance at all, it might seem to suggest a more universal applicability of the right under the Fourteenth Amendment, not limited to the federal government.

Indeed, to conclude that Justice Miller understood all the rights he listed as tied to a citizen's relationship with the federal government would disregard his own introduction to the list, which indicated a clear distinction between those rooted in the "National character" of the federal government and those derived from "the Federal ... Constitution." 212 The sentence in which Miller referred to

misquoting of Crandall by Justice Miller; "federal" references are also added here, based on unambiguous context in Crandall).

${ }^{209}$ I.e., redundant both internally and externally, in that (1) Miller's own opinion had previously set forth the essence of such rights and (2) such rights were already protected by the Supremacy Clause. As Professor Palmer noted, Miller "would have been quite clear had he been talking of petition and assembly in a Crandall $v$. Nevada fashion, as petitioning or assembling for a national purpose." Palmer, supra note 22, at 750; see also 2 CROSSKEY, POLITICS, supra note 49, at 1129 (noting that if Miller's reference to assembly and petition were read in terms of 'seek[ing of the national govemment's] protection,' it would have been directly within the language from the Crandall case that Justice Miller quoted" (brackets added by Crosskey)).

210 See supra note 206.

211 U.S. CONST. amend. I (emphasis added). Dropping "of the people" seems mere trimming of nonessential verbiage, and only a humorless grammarian would complain about Miller's creation of a split infinitive. But cf. AMAR, BLL OF RIGHTS, supra note 63, at 26-32, 244-46 (suggesting that words "of the people" had important limiting significance to generation contemporary to adoption of First Amendment, though less so to contemporaries of Fourteenth Amendment).

212 Slaughter-House, 83 U.S. (16 Wall.) at 79; see also Palmer, supra note 22, at 748 (noting that Miller "listed three sources from which one might derive the privileges or 
assembly, petition, and habeas corpus concluded with the observation that these "are rights of the citizen guaranteed by the Federal Constitution." 213 By contrast, the preceding sentence, referring to a right typical of the rest of Miller's list, indicated that that right "depends upon [the citizen's] character as a citizen of the United States."214

Justice Miller's reference to assembly and petition looks very much, in fact, like a straightforward incorporation of the First Amendment more than fifty years before it was supposed to have happened.215 And why should we not take seriously, at face value, the incorporationist implications of this reference to "privileges and immunities... which owe their existence to the Federal ... Constitution"? 216 It seems a perfectly sensible way to encompass all personal rights set forth in the constitutional text. This reading would certainly give the lie to Justice Field's dissenting protest that the majority's interpretation was "vain and idle."217

Justice Field's description of the majority's approach was partially accurate in that Miller did focus on rights "specially designated in the Constitution or necessarily implied as belonging to citizens of the United States."218 But to the extent such rights included guarantees previously nonbinding on the states, Field plainly erred in suggesting that the Supremacy Clause "always controlled any State legislation" in derogation of such rights. ${ }^{219}$ As Dean Ely reminded us, dissents must be taken with a grain of salt-perhaps a few tablespoons in Field's case! ${ }^{220}$ Field was doubtless unimpressed because the majority's view, even on a total-incorporationist reading, did not produce the result he so ardently felt was just.

Justice Miller had merely "venture[d] to suggest some"221 of the rights protected by the Privileges and Immunities Clause. Having included habeas corpus and two First Amendment guarantees in such an avowedly nonexhaustive

immunities of United States citizens: the requirements of the national character of the federal government, the Constitution, and federal law"); Newsom, supra note 22, at 679 n.176 (making same point).
213 Slaughter-House, 83 U.S. (16 Wall.) at 79.
214 Id.
215 See supra note 91.
216 Slaughter-House, 83 U.S. (16 Wall.) at 79.

217 See id. at 96 (Field, J., dissenting). Cf. ELY, supra note 6, at 197 n.59 ("Including [such constitutionally designated federal rights] as privileges or immunities protected against state action ... was a far from trivial step.").

218 Slaughter-House, 83 U.S. (16 Wall.) at 96 (Field, J., dissenting); see also ELY, supra note 6 , at 197 n.59 (quoting same).

219 See Slaughter-House, 83 U.S. (16 Wall.) at 96 (Field, J., dissenting).

220 See ELY, supra note 6, at 197 n.59.

221 Slaughter-House, 83 U.S. (16 Wall.) at 79. 
list, what other federal right "specially designated in the Constitution" could the majority have intended to exclude? ${ }^{222}$ The incorporationist reading of the opinion has the signal virtue of lending sense and meaning to Miller's analysis, rather than leaving it a puzzling and contemptible exercise in tautology. On that ground alone it should be preferred.

The foregoing renders hugely ironic the fact that Justice Miller was a judicial hero of both Justice Felix Frankfurter and Professor Fairman, the two greatest twentieth-century antagonists of the incorporation theory. ${ }^{223}$ Fairman wrote the standard biography of Miller, nowhere suggesting that he might ever have entertained an incorporationist view of the Fourteenth Amendment, ${ }^{224}$ which lends even greater irony to one scholar's comment that 'Fairman's admiration for Miller was so great that Fairman lost his ability for critical insight where Miller was concerned.' 225

\section{Justices Bradley and Swayne and the Briefs}

Justice Bradley's dissent, joined unreservedly by Justice Swayne, ${ }^{226}$ was the only opinion in Slaughter-House to unequivocally endorse total incorporation. "[W]e are not bound to resort to implication, or to the constitutional history of

222 Freedom of speech, for one, Dean Aynes argued. See Aynes, Miller, supra note 41, at 654 (citing free speech as an "obvious omission" from Miller's list). Aynes argued that assembly and petition, unlike speech, are more easily viewed as "structural" rights tied to a citizen's relationship to the national government. See id. Even leaving aside that Miller himself advertised, as just noted in the text, that his list was nonexhaustive (thus undercutting the significance of any omission), the argument leaves me unpersuaded. Speech might relate to national issues or be directed to the national government just as easily as acts of assembly or petition. All three are merely different aspects of free expression. Indeed, as this article suggests in Part III.C, it is difficult to imagine any workable or sensible regime in which First Amendment freedoms could be protected against state power, but only as to "national" topics. The overwhelming evidence that First Amendment rights, above all else, were understood to be protected by the Fourteenth Amendment, see supra note 87, makes it all the more understandable why Miller would single out two such rights as examples in his illustrative, nonexhaustive list. It does, perhaps, make it seem somewhat odd and grudging of Miller not to highlight freedom of speech as well, but no one ever said Miller was an enthusiastic incorporationist. It should be kept in mind that this was all dicta, having nothing to do with the actual dispute in Slaughter-House. See Newsom, supra note 22, at 679-81 (also cautioning against reading too much into Miller's omission of other Bill of Rights guarantees, and suggesting that Miller was responding to Justice Bradley's dissent, see infra Part II.D, which mentioned assembly and habeas corpus as protected privileges and immunities).

223 See Aynes, Fairman \& Frankfurter, supra note 24, at 1201.

224 See CHARLES FAIRMAN, MR. JUSTICE MILLER AND THE SUPREME COURT, 1862-1890 (1939) (discussed in Aynes, Fairman \& Frankfurter, supra note 24, at 1206, 1209-12).

225 Aynes, Fairman \& Frankfurter, supra note 24, at 1212.

226 See Slaughter-House, 83 U.S. (16 Wall.) at 124 (Swayne, J., dissenting). 
England," Bradley declared, "to find an authoritative declaration of some of the most important privileges and immunities of citizens of the United States. It is in the Constitution itself."227 As he noted, many of those privileges and immunities

were only secured, in express terms, from invasion by the Federal government; such as the right of habeas corpus, the right of trial by jury, of free exercise of religious worship, the right of free speech and a free press, the right peaceably to assemble for the discussion of public measures, the right to be secure against unreasonable searches and seizures, and above all, and including almost all the rest, the right of not being deprived of life, liberty, or property, without due process of law. These, and still others are specified in the original Constitution, or in the early amendments of it, as among the privileges and immunities of citizens of the United States, or, what is still stronger for the force of the argument, the rights of all persons, whether citizens or not. $^{228}$

He later reiterated that one of the chief "mischief[s] to be remedied" by the Fourteenth Amendment was state "intolerance of free speech and free discussion."229

It might be viewed as damaging to the incorporationist reading of the majority opinion that this clearest and most comprehensive exposition of the theory came in dissent. But such a reaction would be superficial and misguided. Almost all of Justice Bradley's dissent was devoted to an exposition of naturalrights views and hostility to monopolies entirely in accord with Justice Field's dissent, 230 which, as noted earlier, Bradley and Swayne also joined. It might also be noted that Bradley was more lucid than Field in conveying that he was addressing both equality issues and substantive rights. ${ }^{231}$ Bradley's discussion of the Bill of Rights took up only a bit more than half a page in a thirteen-page opinion. 232 There is no reason to view it as central or even relevant to his (or Field's) disagreement with the majority. Like Justice Miller, Bradley expressly mentioned habeas corpus and the right of peaceable assembly.

The obvious point of disagreement between Justice Bradley and the majority on incorporation would appear to be that Bradley refused to limit incorporation to rights rooted in the constitutional text. While Bradley seemed anxious to lock

227 Id. at 118 (Bradley, J., dissenting).

228 Id. at 118-19 (Bradley, J., dissenting).

229 Id. at 123 (Bradley, J., dissenting).

${ }^{230}$ See id. at 111-18, 119-24 (Bradley, J., dissenting).

231 See id. at 112 (Bradley, J., dissenting) (noting that two essential questions were raised: first, whether a citizen had a right "to pursue such civil employment as he may choose to adopt, subject to ... reasonable regulations," and second, whether the monopoly at issue was such a reasonable regulation).

232 Compare id. at 118-19 (Bradley, J., dissenting) with id. at 111-18, 119-24 (Bradley, J., dissenting). 
down a textually determinate core of "privileges or immunities," he did not believe that such rights "owe[d] their existence to the Federal ... Constitution."233 Quite the contrary: Immediately after his digression supporting textual incorporation, Bradley resumed his Field-like discourse on natural rights:

But even if the Constitution were silent, the fundamental privileges and immunities of citizens ... would be no less real and no less inviolable than they now are. It was not necessary to say in words that the citizens... should have and exercise [inter alia] ... the privilege of engaging in any lawful employment .... ${ }^{234}$

For Bradley, as for all the other Justices, Slaughter-House revolved around a butchers' monopoly and not the Bill of Rights.

The incorporationist interpretation of the majority opinion is further strengthened by a careful reading of Justice Swayne's dissent, to which both Palmer and Newsom gave short shrift. ${ }^{235}$ Swayne's opinion, though much shorter than the other three, was just as emphatic as Field's or Bradley's in advocating a sweeping scope for the Fourteenth Amendment. Swayne stated that the privileges and immunities of a citizen of the United States encompassed "the fundamental rights of life, liberty, and property, and also the rights which pertain to him by reason of his membership of the Nation."236 There is no doubt that Swayne understood this formula to include the Bill of Rights, because he endorsed Bradley's explicitly incorporationist dissent. The post-Civil War Amendments, Swayne declared, "mark an important epoch in the constitutional history of the country. They trench directly upon the power of the States, and deeply affect

233 Id. at 79 (opinion of the Court).

234 Id. at 119 (Bradley, J., dissenting). In light of this language, it is surprising that Dean Aynes argued that "Justice Bradley offered the manageable standard of using the text of the Constitution as the basis for identifying privileges and immunities." Aynes, Miller, supra note 41 , at 652-53. Aynes conceded in a footnote that "Bradley, of course, also seemed willing to treat the rights guaranteed at common law and catalogued in the Civil Rights Act of 1866 as [defining] privileges and immunities," and stated that "this, likewise, is a manageable standard." Id. at $653 \mathrm{n} .180$. The latter claim is debatable even as stated, and becomes untenable when one recalls that Bradley, like all the other dissenters, joined Field's rhapsodic endorsement of "natural ... rights," "rights which are the gift of the Creator, which the law does not confer, but only recognizes." Slaughter-House, 83 U.S. (16 Wall.) at 96, 105 (Field, J., dissenting). To borrow Aynes's words, it was Justice Miller, not the dissenters, who offered a "manageable" and "textual" standard for interpreting the Privileges and Immunities Clause.

235 See Slaughter-House, 83 U.S. (16 Wall.) at 124-30 (Swayne, J., dissenting). I disagree with Palmer's view that "Swayne's dissent adds little to the argument." Palmer, supra note 22, at 762 n.97; see also Newsom, supra note 22, at 657 (discussing Swayne only with regard to conventional reading of Slaughter-House, and very briefly at that).

236 Slaughter-House, 83 U.S. (16 Wall.) at 126 (Swayne, J., dissenting). 
those bodies. They are, in this respect, at the opposite pole from the first eleven."'237 Tellingly, he footnoted this sentence with a citation to Barron and its progeny. 238

What is most intriguing, however, is that Justice Swayne's dissent also contained language closely tracking Justice Miller's much-criticized dualcitizenship analysis.239 Swayne agreed with Miller that the Fourteenth Amendment created

a double citizenship, each having some rights peculiar to itself. It is only over those which belong to the citizen of the United States that the category here in question [the Privileges and Immunities Clause] throws the shield of its protection. All those which belong to the citizen of a State, except as to bills of attainder, ex post facto laws, and laws impairing the obligation of contracts [three rights guaranteed against state violation by Article I, section 10 of the original Constitution, which Swayne footnoted here], are left to the guardianship of the bills of rights, constitutions, and laws of the States respectively. Those rights may all be enjoyed in every State by the citizens of every other State by virtue of clause 2 , section 4 , article 1 , of the Constitution [an obvious though garbled reference to the Article IV Privileges and Immunities Clause ${ }^{240}$ ] .... This section [the Fourteenth Amendment clause "here in question"] does not in anywise affect them; such was not its purpose. ${ }^{241}$

Justice Swayne seemed to be saying that while the Article IV Clause guarantees out-of-state visitors the right to equal enjoyment of both state and federal rights, the Fourteenth Amendment Clause does not cloak the rights of state citizenship with any additional federal protection. His formalistic "double citizenship" analysis, coupled with the fact that he specifically listed as subject to federal protection only three rights already guaranteed by the pre-1868 Constitution, could very easily suggest the same cramped redundancy that most have found in Justice Miller's opinion. We know this impression of Swayne is misleading because of the other language in his opinion quoted above and because he joined Justice Bradley's opinion. This article suggests that equally careful attention to language and context should likewise dissipate the antiincorporationist impression so many have gotten from Miller's opinion.

237 Id. at 125 (Swayne, J., dissenting).

238 Id. at 125 n.* (Swayne, J., dissenting) (citing Barron v. Baltimore, 32 U.S. (7 Pet.) 243 (1833), and other cases).

239 See supra note 186.

240 The substance and context of the sentence make it obvious that Swayne meant to cite Article IV, Section 2, Clause 1 of the Constitution. Article I, Section 4, Clause 2 of the Constitution (amended in 1933 by Amendment XX, Section 2 of the Constitution) provided that "Congress shall assemble at least once in every Year, and such Meeting shall be on the first Monday in December, unless they shall by Law appoint a different Day."

241 Slaughter-House, 83 U.S. (16 Wall.) at 126-27 (Swayne, J., dissenting). 
One riddle is what, if anything, Justice Field thought about incorporation in 1873.242 Perhaps nothing, since he seemed focused on the issues of natural and equal rights. As we have seen, his only reference in Slaughter-House to the Bill of Rights conveyed, not so much rejection of the incorporation theory, as dissatisfaction that it did not go nearly far enough. When he ultimately did expressly embrace total incorporation in 1892 , he stated that he did so "after much reflection" inspired by an argument made to the Court in 1887, and both that argument and his 1892 analysis embraced, ironically, the textualist approach of the Slaughter-House majority. ${ }^{243}$ On the other hand, Field in Slaughter-House did not expressly exclude Bill of Rights guarantees from his natural-law conception of the "sacred and imprescriptible rights of man."244 There are, however, for Field as well as Justices Bradley, Swayne, Woods, and even Harlan, a number of puzzling cases and votes over the ensuing years which require discussion. Indeed, it appears, with varying degrees of clarity, that Bradley, Swayne, and Woods later abandoned the incorporation theory. 245

There was relatively little mention of the Bill of Rights in the briefs filed in Slaughter-House. For the most part, the briefs filed by the attorneys for the butchers excoriated the evils of monopolies and advocated the same far-reaching natural rights proclaimed in the dissents. ${ }^{246}$ They did refer, however, to Bill of

242 The same riddle applies to Chief Justice Chase, who joined Field's opinion and no other, and died less than a month after Slaughter-House was decided. See Slaughter-House, 83 U.S. (16 Wall.) at 57; id. at 111 (Field, J., dissenting); OXFORD SUPREME COURT, supra note 39, at 967. It seems reasonable to suppose that Chase embraced an incorporationist view of the Fourteenth Amendment, given his alignment with the other Slaughter-House dissenters (all of whom either then or later expressly endorsed that view), his generally broad reading of the Amendment, and his strong, consistent, career-long support for civil rights. $C f$. Richard $\mathrm{L}$. Aynes, Bradwell v. Illinois: Chief Justice Chase's Dissent and the "Sphere of Women's Work," 59 LA. L. REv. 521 (1999) (discussing Chase's beliefs in civil rights and proposing a hypothetical opinion which Chase might have written in Bradwell had he not been too ill). If so, he would be the seventh Supreme Court Justice of the nineteenth century (and the only Chief Justice, in any century) ever to have embraced such a view. See supra Part I.A; supra note 38.

243 See O'Neil v. Vermont, 144 U.S. 323, 361 (1892) (Field, J., dissenting); Spies v. Ilinois, 123 U.S. 131, 143-55 (1887) (argument of John Randolph Tucker); see also Wildenthal, Road to Twining, supra note 4, at Parts II.D and III.A.

244 Slaughter-House, 83 U.S. (16 Wall.) at 110 (Field, J., dissenting).

245 See infra Parts III.B-C and IV; Wildenthal, Road to Twining, supra note 4, at Part II.

246 See generally Brief for Plaintiffs (filed by John A. Campbell), Slaughter-House Cases, 83 U.S. (16 Wall.) 36 (1873) [hereinafter Slaughter-House Plaintiffs' Opening Brief (Campbell)]; Supplemental Brief for Plaintiffs (filed by John A. Campbell and J.Q.A. Fellows), Slaughter-House Cases, 83 U.S. (16 Wall.) 36 (1873); Brief for Plaintiffs on Reargument (filed by John A. Campbell), Slaughter-House Cases, 83 U.S. (16 Wall.) 36 (1873); Brief for Plaintiffs on Reargument (filed by J.Q.A. Fellows), Slaughter-House Cases, 83 U.S. (16 Wall.) 36 (1873) [hereinafter Slaughter-House Plaintiffs' Reargument Brief (Fellows)]. The Supreme 
Rights guarantees, and they explicitly asserted that such guarantees were now protected against the states by the Fourteenth Amendment. This article appears to be the first scholarly work to provide any substantial discussion of this aspect of the Slaughter-House briefs. ${ }^{247}$

For example, the plaintiffs' opening brief, referring to rights set forth in the First, Fourth, and Fifth Amendments, declared:

The constitution before [the Reconstruction Amendments] had recognized rights and privileges as beyond the legislation of Congress. Religion and speech and publication could not be subjects of legislation for Congress. Congress could not pass bills of attainder or ex post facto laws, or violate the rights of person or property by unreasonable searches or seizures, nor deprive any of [sic] life, liberty or property, without due process of law. But the [Reconstruction] amendments ... go further and declare the native population shall be citizens of the United States-that they shall be free-that their immunities and privileges shall never be abridged by State laws ....248

The same brief later reiterated:

Before [the Reconstruction] amendments, the rights of conscience, of speech, of publication, of labor, of intercourse and liberty, and security, were scarcely protected by the Constitution of the United States from State legislation. The bill of rights appended to the constitution was limited to declaring a protection against federal legislation or aggression. The rights of an American citizen by the [Reconstruction] amendments have the safeguard of the entire power of the nation. Conscience, speech, publication, security, occupation, freedom, and whatever else is essential to the liberty, or is proper as an attribute of citizenship, are now held under the guarantee of the Constitution of the United States. ${ }^{249}$

The author of this brief, John A. Campbell, was himself a highly respected former Supreme Court Justice, appointed in 1853. He resigned his seat in 1861 upon the secession of his home state of Alabama, and became the Assistant

Court briefs in Slaughter-House are reprinted in 6 LANDMARK BRIEFS AND ARGUMENTS OF THE SUPREME COURT OF THE UNITED STATES: CONSTITUTIONAL LAW 473-732 (Philip B. Kurland \& Gerhard Casper eds., 1975) [hereinafter LANDMARK BRIEFs].

247 See infra note 252.

248 Slaughter-House Plaintiffs' Opening Brief(Campbell), supra note 246, at 11-12.

249 Id. at 37 (emphases added); see also id. at 40 (responding to argument that Louisiana law was within state police power by stating: "What are those clauses of the Constitution that protect the freedom of speech, of press, of persons and houses from searches and seizures; that allow bail to criminals, and a fair trial and reasonable punishment for crime, but restraints on the police power.'). The brief referred, of course, to the First, Fourth, Fifth, Sixth, and Eighth Amendments. 
Secretary of War of the Confederacy. ${ }^{250}$ Southern Democrats and former Confederates like Campbell had bitterly opposed the Fourteenth Amendment but "Campbell now waved it like a battle flag for the butchers."251 Campbell's proincorporation argument in Slaughter-House, though off-point to the precise issue before the Court, is strikingly consistent with the support for incorporation-and the incorporationist reading of Slaughter-House-by other Southern Democrats and former Confederates during the early 1870s, as discussed in Part III.A.1.

On reargument, Campbell's co-counsel J.Q.A. Fellows submitted a brief devoted to a close examination of the legislative history of the Reconstruction Amendments and contemporary civil rights statutes. Fellows quoted from Representative Bingham's key speech introducing the first version of what later became Section 1 of the Fourteenth Amendment, in which Bingham explained that it met the necessity of enforcing the Bill of Rights against the states:

"[T]his immortal bill of rights embodied in the Constitution, rested for its execution and enforcement hitherto upon the fidelity of the States. The House knows, the country knows, the civilized world knows, that the legislative, executive and judicial officers of eleven States within this Union, within the last five years, have utterly disregarded the behest." 252

250 See OXFORD SUPREME COURT, supra note 39, at 116-17; PETER IRONS, A PEOPLE'S HISTORY OF THE SUPREME COURT 199 (1999); Aynes, Miller, supra note 41, at 633 \& n.33.

251 IRONS, supra note 250, at 199.

252 Slaughter-House Plaintiffs' Reargument Brief (Fellows), supra note 246, at 16 (quoting CONG. GLOBE, 39th Cong., 1st Sess. 1034 (Feb. 26, 1866)). Campbell touched somewhat indirectly on the incorporation issue in his oral argument before the Court. See Oral Argument of John A. Campbell, Slaughter-House Cases, 83 U.S. (16 Wall.) 36 (1873), Feb. 34,1873 , at 29, reprinted in 6 LANDMARK BRIEFS, supra note 246, at 733, 762 (arguing that prior to the Fourteenth Amendment, "this Court had the judicial power of enforcement [only, as to the states] of those clauses of the Constitution which" [isting several rights secured expressly against state violation by the original Constitution, see U.S. CONST. art. I, § 10], whereas under the Fourteenth Amendment, "[e]very act of the [state] Legislature that ... abridg[es] the privileges or immunities which [any individual] claims to have as a citizen ... become[s] subject to the control or revisory power of this Court").

Dean Aynes briefly noted the references in the Slaughter-House Plaintiff's' Reargument Brief (Fellows), supra note 246, to the congressional debates on the Fourteenth Amendment, including Bingham's speech, see Aynes, Bingham, supra note 54, at 98-99 \& n.266, but he did not mention the other support for incorporation in the briefs (it was not relevant to his discussion of Bingham). Justice Black mentioned and quoted the Fellows brief's quotation of Bingham's speech. See Adamson v. California, 332 U.S. 46, 76 n.7 (1947) (Black, J., dissenting). But Black apparently overlooked the other support for incorporation in the briefs, for he stated that he found no "indication that the Court [in Slaughter-House] was presented with documented argument on the question of whether the Fourteenth Amendment made the Bill of Rights applicable to the States." Id. Newsom, surprisingly given his extensive discussion of the incorporationist reading of Slaughter-House and his citation and discussion of the briefs 
The defendants' briefs, with one minor and dubious exception, did not specifically dispute or even address the pro-incorporation arguments of the plaintiffs. ${ }^{253}$ It would hardly have behooved them to take such a stance when it (1) was far more restrictive than necessary to secure victory for their clients, (2) ran counter to plain text not yet construed by the Supreme Court, (3) contradicted the legislative history cited by the other side, and (4) posed a risk of antagonizing those Justices, notably Bradley, who might well have been thought likely to embrace the theory. ${ }^{254}$ The failure of the defendants to mount any significant rebuttal to the plaintiffs' incorporationist arguments may also be explained by the fact that their attorneys included two Republican politicians, who would not be expected to advocate an unduly narrow interpretation of the

on certain other points, see supra note 54 (citing Newsom, supra note 22, at 658-62, 695), also apparently overlooked this aspect of the briefs.

253 See generally Brief for Defendants (filed by Charles Allen), Slaughter-House Cases, 83 U.S. (16 Wall.) 36 (1873) [hereinafter Slaughter-House Defendants' Opening Brief (Allen)]; Supplemental Brief for Defendants (filed by Thomas J. Durant), Slaughter-House Cases, 83 U.S. (16 Wall.) 36 (1873); Brief for Defendants on Reargument (filed by Thomas J. Durant), Slaughter-House Cases, 83 U.S. (16 Wall.) 36 (1873) [hereinafter Slaughter-House Defendants' Reargument Brief (Durant)]. But see Brief for Defendant in No. 479 (filed by Thomas J. Durant), at 5, Slaughter-House Cases, 83 U.S. (16 Wall.) 36 (1873) [hereinafter Slaughter-House Defendant's Brief in No. 479] (asserting that Privileges and Immunities Clause "plainly refers to political privileges, and shields only such privileges and immunities as individuals may have in their peculiar character as citizens of the United States, i.e., the privilege of voting, holding office, \&c., or the immunity from certain public charges and duties, such as jury duty, military service, \&c."). The latter bit of shoddy briefing suggests an affinity with the tautological reading of the majority opinion, if it can be given any coherent meaning. "Political privileges" like voting are the one thing the Article IV Clause plainly cannot encompass, though Durant may have relied on Justice Washington's erroneous "elective franchise" dictum in Corfield, which was not authoritatively rejected until two years after Slaughter-House was decided. See supra note 143. Nor could any voting privileges have been encompassed by the Fourteenth Amendment Clause at the time of its ratification. Later amendments, including the Fifteenth (which had been ratified at the time Durant wrote), did establish some voting-related privileges of United States citizenship, which might be viewed as after-acquired (though redundant) components of the Fourteenth Amendment Clause. See supra notes 94,143 , and 146 . It was sheer nonsense to include "immunity from ... jury duty [or] military service." Slaughter-House Defendant's Brief in No. 479, supra, at 5. Durant's brief on reargument argued, more sensibly (and quite consistently with the incorporation theory), that the Fourteenth Amendment Clause did not protect "a natural right to keep stocklandings and slaughter-houses .... Natural rights, whatever they may be elsewhere, are, in a court of law, only such as the law recognizes and protects." Slaughter-House Defendants' Reargument Brief (Durant), supra, at 13.

254 Justice Bradley had already publicly embraced a broadly nationalistic theory of the Fourteenth Amendment in circuit court litigation arising from these very same cases, and his judicial comrade in that decision had explicitly embraced the theory of total incorporation in two other cases. See supra notes 110-12. 
Fourteenth Amendment. ${ }^{255}$ Rather, the defendants focused on the broad police powers of the state, offering at one point a most impressive parade of homibles regarding the consequences for the federal-state balance of power if the Court were to accept the sweeping scope of nationally protected privileges and immunities for which the butchers contended. 256

The defendants also pointed to the undeniably central purpose of the Reconstruction Amendments to ensure freedom and equal rights for the former slaves. ${ }^{257}$ Justice Miller's language reiterating that central purpose is often cited and criticized as unduly narrowing their scope, 258 but it is just as often overlooked that his opinion went on to carefully acknowledge that the Amendments were not limited to that purpose:

We do not say that no one else but the negro can share in [their] protection. Both the language and spirit of these articles are to have their fair and just weight in any question of construction.... And so if other rights are assailed by the States which properly and necessarily fall within the protection of these articles, that protection will apply, though the party interested may not be of African descent. 259

The incorporationist arguments of Campbell and Fellows did not directly advance their clients' cause, and they may have been wary of emphasizing such textual rights in light of their dependence on natural law arguments. Note how the second excerpt quoted above carefully interwove references to textual and

255 See Aynes, Miller, supra note 41, at 633 (noting that defendants' attomeys included "Republican Senator Matthew Carpenter" and "Louisiana radical Republican politician Thomas Jefferson Durant'). Oral argument for the defendants was presented by Carpenter, Durant, and Jeremiah S. Black, a former U.S. Supreme Court Reporter and Democratic U.S. Attomey General. See Slaughter-House, 83 U.S. (16 Wall.) at 57; Aynes, Miller, supra note 41, at 633 .

256 See Slaughter-House Defendants' Opening Brief (Allen), supra note 253, at 12-13 (arguing that plaintiffs' view would bring within national jurisdiction all laws regarding, inter alia, employment licensing, dangerous trades and articles, manufacture and sale of intoxicating liquors, Sunday closing laws, maximum-hour and child-labor laws, and any exclusive economic privileges). The reference to maximum-hour and child-labor laws accurately forecasts the Lochner doctrine which grew out of Field's dissent. See supra Part II.B.

257 See, e.g., Slaughter-House Defendants' Opening Brief (Allen), supra note 253, at 1617; Slaughter-House Defendants' Reargument Brief (Durant), supra note 253, at 7-8, 15.

258 See Slaughter-House, 83 U.S. (16 Wall.) at 71-72; KACZOROWSKI, POLrmCS, supra note 88 , at 150-51; NELSON, supra note 88, at 162-63; Curtis, Resurrecting, supra note 41 , at $72-73$.

259 Slaughter-House, 83 U.S. (16 Wall.) at 72; see also Palmer, supra note 22, at $743 \mathrm{n} .22$ (noting that this "passage is a clear refutation of the 'black-only' allegation levelled at Miller"); Newsom, supra note 22, at 683-86 (making similar point, and suggesting that Miller's emphasis on freed slaves was in response to overbroad claims of Field's dissent on behalf of white butchers). 
nontextual rights. But these arguments do indicate, contrary to Professor Morrison's suggestion, that incorporation was very much an idea "abroad" among lawyers of the day, ${ }^{260}$ and far less controversial then than it later came to seem. They suggest that incorporation was on the minds of all the SlaughterHouse Justices, and that the majority's incorporationist dicta should be taken at full face value.

Indeed, Professor Morrison completely missed the boat with regard to Slaughter-House. That he overlooked the incorporationist implications of Justice Miller's opinion is perhaps understandable, for the narrow conventional reading was by then embedded in precedential concrete. But Morrison also failed even to mention Justice Bradley's and Justice Swayne's views, three times omitting them from his account of the nineteenth-century Justices who ever supported incorporation, even though Justice Black had discussed and quoted extensively from Bradley's opinion in the very case to which Morrison's article responded. ${ }^{261}$ And in further disregard of Bradley, and without (apparently) having read the briefs, Morrison stated that in Slaughter-House, "the question of whether the [Fourteenth] Amendment incorporates the Bill of Rights was not raised,"262 and that "[ $t$ ] he theory [of incorporation] does not appear even to have been presented to th[e] Court in the argument of counsel until 1887.'263

\section{E. The Textual Incorporation Compromise}

Is all this enough, in the end, to warrant the conclusion that in SlaughterHouse "all nine [Justices] appear with varying degrees of clarity to have endorsed [the proposition] that whatever else it did, the Privileges or Immunities Clause at least applied to the states the constitutionally stated prohibitions that had previously applied only to the federal government"? ${ }^{264}$ One has to wonder why the majority, given the ferocious criticism it faced from the dissenters, did not tout more proudly its incorporationist credentials, if that is the correct reading. It is dubious, however, whether such a reading, even if more vigorously expressed, would have mollified the dissenters. Given their natural-rights bent, they may truly have been little more reconciled to a textualist theory of total incorporation, limited to rights "which owe their existence to the Federal ... Constitution,"265 than to the tautological reading traditionally given to Justice Miller's opinion.

${ }^{260}$ Cf. Morrison, supra note 6, at 151.

261 See id. at 151, 159-60, 172 n.63; see also Adamson v. Califomia, 332 U.S. 46, 75 n.6, 120-21 (1947) (Black, J., dissenting).

262 Morrison, supra note 6, at 144.

263 Id. at 159.

264 ELY, supra note 6, at 197 n.59.

265 Slaughter-House, 83 U.S. (16 Wall.) at 79. 
As various scholars have noted, the primary difficulty with total incorporation from the standpoint of the original understanding lies not in supporting it, but in limiting it to the Bill of Rights. ${ }^{266}$ Justice Bradley's view that the Privileges and Immunities Clause encompasses not only textual guarantees such as those found in the Bill of Rights, but also a wide and ill-defined range of others, is strongly supported by the legislative history. Senator Howard, in his 1866 speech introducing the Fourteenth Amendment in the Senate-before "add[ing]" the Bill of Rights to his catalogue of privileges and immunities ${ }^{267}$ observed that such rights "are not and cannot be fully defined in their entire extent and precise nature." 268

It is important, however, not to lose sight of the straightforward text of the Privileges and Immunities Clause. The second Justice John Marshall Harlandisputing a theory of which, ironically, his grandfather was one of the greatest champions ${ }^{269}$-once argued that this text is "an exceedingly peculiar way" to express the principle of total incorporation. ${ }^{270}$ In fact, it is a very concise and compelling way to express that idea. As a law student in 1988, the author of this article came up with a simple syllogism capturing the logic of incorporation via the Clause. It went something like this: (1) The Clause undeniably restricts state power with regard to a class of rights (hint: read the Clause). (2) It had to accomplish something; therefore, the rights protected must have been ones the states were previously free to infringe as far as the Constitution was concerned (hint: see Barron). (3) The language, "privileges or immunities of citizens of the United States," indicates that those rights were already guaranteed in some sense to United States citizens (hint: see the Bill of Rights). (4) Therefore, the "privileges or immunities of citizens of the United States" that "[n]o State shall ... abridge" must be those that simultaneously meet criteria (2) and (3).

It should not take Holmesian abilities (either those of Oliver Wendell or Sherlock) to fill in that blank. Professor Amar demonstrated the textual logic of

266 See, e.g., ELY, supra note 6, at 28; MALTZ, CIVIL RIGHTS, supra note 63, at 113. Some scholars have argued that the scope of the Privileges and Immunities Clause is tied to amorphous concepts of natural rights rather than any strict textual source. See generally, e.g., CHESTER JAMES ANTIEAU, THE INTENDED SigNIFICANCE OF THE FOURTEENTH AMENDMENT 47-63, 207-30 (1997); BOND, supra note 82, at 255-57; Trisha Olson, The Natural Law Foundations of the Privileges or Immunities Clause of the Fourteenth Amendment, 48 ARK. L. REV. 347 (1995); Smith, Natural Law, supra note 147.

$267 \mathrm{He}$ had already quoted in full the sweeping language of Corfield $v$. Coryell, $6 \mathrm{~F}$. Cas. 546, 551-52 (C.C.E.D. Pa. 1825). See CONG. GlOBE, 39th Cong., 1st Sess. 2765 (May 23, 1866).

268 CONG. GLOBE, 39th Cong., 1st Sess. 2765 (May 23, 1866).

269 See generally Wildenthal, Road to Twining, supra note 4.

270 Duncan v. Louisiana, 391 U.S. 145, 175 n.9 (1968) (Harlan, J., dissenting); see also $i d$. at 165-67 (Black, J., concurring) (laying out Justice Black's effective rejoinder). 
incorporation in considerably more elaborate detail in his 1992 article. ${ }^{271}$ It is worth noting, in particular, that Amar completed the work of Professors Crosskey and Curtis by destroying once and for all the textual argument that incorporation of the Bill of Rights, and hence, the Fifth Amendment Due Process Clause, would render the Fourteenth Amendment Due Process Clause redundant.272

It seems clear that Justice Miller and his majority colleagues intended to strike a reverberating blow against what they feared would be the consequences of an untrammeled nationalist interpretation of the Reconstruction Amendments. They adhered in Slaughter-House to a more traditionally federalist and states'rights vision of the Constitution. This obviously disappointed the expectations of many supporters of the Amendments who believed they had conferred on the federal government plenary authority over "the natural rights of freemen."273 On the other hand, Miller was perhaps not as out of touch with the contemporary

271 See Amar, supra note 22, at 1218-26; see also Curtis, Resurrecting, supra note 41, at 20-26; Michael Kent Curtis, Two Textual Adventures: Thoughts on Reading Jeffrey Rosen's Paper, 66 GEO. WASH. L. REV. 1269, 1271-72 (1998).

272 This argument has a long lineage, see, e.g., BERGER, FOURTEENTH, supra note 60, at 91-92; Morrison, supra note 6, at 158-59; Fairman, supra note 22, at 58-59; D.O. McGovney, Privileges or Immunities Clause, Fourteenth Amendment, 4 IowA L. BULL. 219, 233 (1918), and even confounded Dean Ely, see ELY, supra note 6, at 27 (stating that it did "great damage to the incorporation thesis"). But Amar showed that the references to "citizens" in the Privileges and Immunities Clause and "person" in the Due Process and Equal Protection Clauses reflected a distinction that was significant, intentional, and well understood in the congressional debates, and designed to ensure that, while all citizens would receive the comprehensive benefit of the former, every "person," whether citizen or alien, would receive the core essential protections of the latter. See Amar, supra note 22, at 1224-26. But see Smith, Reconstruction or Reaffirmation?, supra note 63, at 187-88 (arguing that Amar's resolution still leaves some unanswered questions). On this, as on so many points relating to incorporation, Amar walked in the footsteps of Crosskey and Curtis. See Amar, supra note 22, at 1225 n.145 (citing, inter alia, Crosskey and Curtis); see also CURTIS, No STATE, supra note 22, at 107 (similarly refuting supposed redundancy of Fourteenth Amendment Due Process Clause); Crosskey, supra note 61, at 76-77 (same). The stubbomness of the late Professor Berger's views on incorporation is reflected in the fact that he repeated this redundancy objection as late as 1997, without even mentioning these refutations of it by Amar, Curtis, and Crosskey - five, eleven, and forty-three years before, respectively. See BERGER, GOVERNMENT 1997, supra note 62, at 181; see also supra note 64. Amar also disposed of another textual objection to incorporation, relating to the fact that Bill of Rights guarantees have been viewed as protecting both citizens and aliens under American jurisdiction. See Amar, supra note 22, at 1222-23; see also Maxwell v. Dow, 176 U.S. 581, 595-96 (1900); Wildenthal, Road to Twining, supra note 4, at Part IV. As to why the Fourteenth Amendment did not simply refer to "the Bill of Rights" or "Amendments I to VIII," Curtis and Amar have pointed out that a number of privileges and immunities may be found scattered in the original Constitution as well as in the first eight amendments. See Amar, supra note 22, at 1227-28; Curtis, Response, supra note 62 , at 120 .

273 KACZOROWSKI, POLITICS, supra note 88, at 159. 
understanding of the Amendments as Professor Kaczorowski has argued. ${ }^{274}$ As Professors Berger and Brandwein have pointed out, many Republicans of the time, though supporting Reconstruction and the necessary changes wrought by the Amendments, nevertheless adhered, like the Slaughter-House majority, to a fundamentally traditional conception of the federal-state balance. ${ }^{275}$

Clearly, the Fourteenth Amendment was designed to sharply limit the power of the states to abuse the fundamental rights of American citizens. Just as clearly, it was not meant to obliterate state power or radically alter the federal-state balance. We should not too hastily conclude that, just because Justice Miller rejected the broadest nationalistic reading of the Amendment, he actually intended, as the dissenters angrily alleged, to render it a "vain and idle enactment."276 It is time to reconsider the closing words of Miller's opinion and reassess whether the majority honestly embraced a reasoned compromise approach:

The adoption of the first eleven amendments to the Constitution so soon after the original instrument was accepted, shows a prevailing sense of danger at that time from the Federal power. And it cannot be denied that such a jealousy continued to exist ... until the breaking out of the late civil war. It was then discovered that the true danger to the perpetuity of the Union was in ... the State[s] ....

Unquestionably, this has given great force to the argument... of those who believe in the necessity of a strong National government.

But, however pervading this sentiment, and however it may have contributed to the adoption of the amendments we have been considering, we do not see in [them] any purpose to destroy the main features of the general system... [O]ur statesmen have still believed that the existence of the States with powers for domestic and local government... was essential to the perfect working of our complex form of government, though they have thought proper to impose additional limitations on the States, and to confer additional power on ... the Nation.

... [T] his court... has always held with a steady and an even hand the balance between State and Federal power, and we trust that such may continue ... so long as it $[s]$... duties ... demand of it a construction of the Constifution, or of any of its parts. 277

As discussed in Part IV, an incorporationist reading of the Fourteenth Amendment limited to textually demonstrable "privileges or immunities of

${ }^{274}$ Cf. id. at $149-66$.

275 See BERGER, FOURTEENTH, supra note 60, at 49-66; BERGER, GOVERNMENT, supra note 33, at 230-45; BRANDWEN, supra note 41, at 5-7, 57-58, 135-36.

276 Slaughter-House, 83 U.S. (16 Wall.) at 96 (Field, J., dissenting).

277 Id. at 82 (opinion of the Court) (emphasis added). 
citizens of the United States"278 is a reasonable, indeed a conservative, compromise completely within the spirit of Miller's philosophy as reflected in the quotation above.

Kevin Newsom's recent article presented important new evidence that this reading of the Amendment and of Slaughter-House is consistent with Justice Miller's jurisprudential philosophy. ${ }^{279}$ Perhaps most intriguingly, Newsom discussed a speaking tour of the Pacific coast by Bingham, the father of the Fourteenth Amendment and the incorporation theory, undertaken in the summer of 1871 "only several months after Bingham had expressly reiterated his incorporationist intentions on the floor of the House (and, incidentally, less than two years before the decision in Slaughter-House was announced). During the trip, 'Bingham was almost daily expounding his views of the [Fourteenth] Amendment's scope and purpose." 280 Bingham's traveling companion on this trip was none other than Miller. ${ }^{281}$ Furthermore, as Newsom showed, Miller was very likely aware of the incorporationist speeches regarding the Amendment by Bingham and Howard in 1866,282 and Miller took original intent very seriously in constitutional adjudication. ${ }^{283}$

This article disagrees with Newsom's analysis of post-Slaughter-House cases, as discussed in Parts III.B, III.C, and IV, but not in a way undermining the incorporationist reading of Slaughter-House itself. If it is even possible to so read Justice Miller, why should we not prefer that reading over one that renders the Clause tautological and depicts the majority as cynically and dishonestly effecting its judicial repeal? A very powerful reason to prefer the incorporationist reading is that members of Congress across the political spectrum embraced precisely such a reading in the wake of the decision, as discussed in Part III.A.1.

278 Professor Antieau argued that it was "unfortunate," even a "tragedy," that Rep. Bingham and his colleagues in the 39th Congress added this critical qualifying language, and he argued that its apparent limiting effect was not intended. See ANTIEAU, supra note 266, at 49-50. But see supra note 272 (discussing scholarship concluding that use of "citizens" in Privileges and Immunities Clause, as opposed to "person" in Due Process and Equal Protection Clauses, was intentional and its impact well understood).

${ }^{279}$ See Newsom, supra note 22, at 675-77, 681, 688-733.

$280 \mathrm{Id}$. at 700 (quoting HOWARD JAY GRAHAM, EVERYMAN's CONSTITUTION $134 \mathrm{n} .90$ (1968)).

281 See id.

282 See id. at 700-02.

283 See id. at 696, 702-03. 


\section{THE POST-SLAUGHTER-HOUSE UNDERSTANDING: THE UNRAVELING CONSENSUS}

\section{A. The Understanding in Congress}

Soon after Slaughter-House, the Supreme Court rejected two claims under the Privileges and Immunities Clause that did not involve incorporation of the Bill of Rights. 284 Over the next sixty years, even as the Court made liberal use of the Due Process Clause to strike down progressive economic regulations, ${ }^{285}$ the Privileges and Immunities Clause remained as useless to those attacking such legislation as it proved to those seeking protection of individual liberties guaranteed by the Bill of Rights. ${ }^{286}$ Right up to the present day, only one extant (and very recent) Supreme Court decision has ever upheld a claim under the Clause, and that did not involve any Bill of Rights guarantee. ${ }^{287}$ And yet, it did not have to be that way.

\section{The Civil Rights Bill Debates of 1873-1874}

Congressional debates during the year after Slaughter-House was decided on April 14, 1873,288 suggest that total incorporation was well understood to be the compromise that decision had arrived at. This was a logical continuation of the congressional support for incorporation seen in 1871-72.289 In 1873-74, Congress continued its lengthy debate over the bill that would later become the

284 See Bradwell v. Mllinois, 83 U.S. (16 Wall.) 130 (1873) (rejecting woman's claim of admission to privilege of practicing law); Bartemeyer v. Iowa, 85 U.S. (18 Wall.) 129 (1874) (rejecting claim of privilege to sell intoxicating liquor). Though incorporation was not even remotely at issue in Bartemeyer, Justice Miller's opinion for the Court contains dicta perfectly consistent with the incorporationist reading of his Slaughter-House majority opinion. See Bartemeyer, 85 U.S. (18 Wall.) at 133 (observing that "the rights of the citizen previously existing, and dependent wholly on State laws for their recognition, are now placed under the protection of the Federal government, and are secured by the Federal Constitution").

285 See supra Part II.B (discussing Lochner doctrine).

286 In 1940, the Court overruled its sole decision up to that time striking down a state law under the Privileges and Immunities Clause. See Madden v. Kentucky, 309 U.S. 83, 90-93 \& nn.13-20 (1940) (overruling Colgate v. Harvey, 296 U.S. 404 (1935), and collecting cases since Slaughter-House rejecting claims under the Clause, most not involving incorporation); see also supra note 105.

287 See Saenz v. Roe, 526 U.S. 489 (1999); see also Edwards v. California, 314 U.S. 160, 177 (1941) (Douglas, J., concurring); id. at 181 (Jackson, J., concurring); supra Parts I.A (briefly discussing Saenz) and II.A (briefly discussing Saenz and Edwards).

288 Slaughter-House, 83 U.S. (16 Wall.) at 57.

${ }^{289}$ See supra Part II.A. 
Civil Rights Act of 1875, which, as proposed, sought to prohibit racial discrimination in public accommodations, transportation, and schools. ${ }^{290}$ Even the most conservative and racist Democratic opponents of the civil rights bill embraced with no apparent qualms the view that the Fourteenth Amendment totally incorporated the Bill of Rights. They advanced this reading as a conservative alternative to the even broader reading urged by Republican proponents of the bill, who believed that the Amendment authorized Congress to legislate equal access without regard to race to a wide range of accommodations and amenities in both the public and private sectors. ${ }^{291}$

Thus, the theory that the Amendment at least incorporates the textual guarantees of the Bill of Rights appears to have emerged after Slaughter-House as a conservative, baseline position. It was common ground in the otherwise deep and bitter disputes that racked Congress over the scope of the Reconstruction Amendments and Congress's power to enforce them. Indeed, Professor Eric Foner, the most distinguished historian of Reconstruction, stated in the leading modern work on this Era that 'the doctrine of 'incorporation'-that the states were now required not to violate the Bill of Rights-had by 1874 become a virtually noncontroversial minimum Congressional interpretation of the Amendment's purposes. ${ }^{.292}$

Surprisingly, however, scholars have long overlooked the stunningly important fact that these members of Congress explicitly and repeatedly cited Justice Miller's majority opinion in Slaughter-House as an authority for this incorporationist reading of the Amendment! ${ }^{293}$ For example, Representative

290 See 2 CONG. REC. 340 (Dec. 19, 1873) (Rep. Benjamin F. Butler, R-Mass.); Michael W. McConnell, Originalism and the Desegregation Decisions, 81 VA. L. REV. 947, 984-86 (1995) [hereinafter McConnell, Desegregation]. School desegregation was dropped from the bill as finally enacted. See Civil Rights Act of 1875, ch. 114, 18 Stat. 335; McConnell, Desegregation, supra, at 1080-86.

291 It was the 1875 Act's reach into the private sector that resulted in its invalidation by the Court in the Civil Rights Cases, 109 U.S. 3 (1883). But see McConnell, Desegregation, supra note 290 , at 1089-91 (challenging this conventional view and arguing that state action was not key issue).

292 FONER, supra note 88, at 533.

293 Previous scholars have discussed some of these congressional statements, without noticing the connection to Slaughter-House, beginning (it appears) with Alfred Avins in 1968. See Avins, supra note 62, at 8-9. I was first alerted to these statements by Professor Curtis's 1986 book. See CURTIS, No STATE, supra note 22, at 166-68. Professor Foner's brief comment in his 1988 book, see supra text accompanying note 292, was the extent of his discussion (not surprisingly in a general one-volume history of the entire Reconstruction Era). Dean Aynes provided a useful summary in his 1993 article. See Aynes, Bingham, supra note 54, at 80 \& nn.135-138; see also HALBROOK, supra note 52, at 150-51; Maltz, Concept, supra note 52, at 525-29, 534. Stephen Halbrook and Professor Maltz appear to be the only scholars prior to this article to have noticed the connection to Slaughter-House. Halbrook's 1998 book briefly 
James B. Beck, Democrat of Kentucky, ${ }^{294}$ noting that the Court "very recently considered these questions in the slaughter-house cases, [and] carefully examined the bearings of the constitutional amendments on this subject" proceeded to quote at length from Justice Miller's discussion of the scope of the Privileges and Immunities Clause. ${ }^{295} \mathrm{He}$ then declared that "[t]he first ten amendments to the Constitution ... go far... in asserting what the rights of citizens of the United States shall be" and proceeded to read verbatim the entire Bill of Rights. ${ }^{296} \mathrm{He}$ concluded that "[t]hese are the rights of a citizen of the United States which the fourteenth amendment declares no State shall abridge. The Supreme Court recognizes them, and goes on to enumerate a few others of the same general character in the case [Slaughter-House] I have quoted from."297

discussed some of these statements in regard to whether the Fourteenth Amendment made an individual right to bear arms applicable to the states. He briefly noted the connection to the Slaughter-House majority opinion drawn by Rep. Beck, see infra text accompanying notes 295-97, but, while also briefly discussing statements by Rep. Mills (misidentified as "Robert Mills") and Sen. Norwood, see infra text accompanying notes 298-303 and 311-16, did not note the similar connections they drew. See HALBROOK, supra note 52, at 150-51. Maltz's 1999 article briefly noted that Sen. Norwood "explicitly linked [his incorporationist] view[s] with the Slaughter-House Cases themselves," and that, "[b]y contrast, no one [in these congressional debates] seems to have suggested that Miller's opinion threatened the theory of incorporation." Maltz, Concept, supra note 52, at 529. Like Halbrook, however, Maltz did not further explore this fascinating and long-overlooked connection. This article, as far as I know, is the first to do so.

294 To avoid needless clutter of repeated citations, let it be noted here that the full names, states, and party affiliations of members of Congress discussed here, to the extent not made clear in the cited pages of the Congressional Record, are taken from CONGRESSIONAL QUARTERLY'S GUIDE TO U.S. ELECTIONS 785-811, 1021-31 (3d ed. 1994) [hereinafter U.S. ELECTIONS].

2952 CONG. REC. 342 (Dec. 19, 1873).

296 Id. at 342-43.

297 Id. at 343. The racist tenor of the opposition to the civil rights bill by Rep. Beck and others is well illustrated by Beck's sarcastic argument that "I suppose there are gentlemen on this floor who would arrest, imprison, and fine a young woman in any State of the South if she were to refuse to marry a negro man on account of color, race, or previous condition of servitude...." Id. This prompted African-American Rep. Joseph H. Rainey (R-S.C.) to respond:

I am contented to marry one of my own complexion ... because I believe that the race of people I represent, to the extent of the opportunities which they have had, and considering how recently they have escaped from the oppression and wrongs committed upon them, are just as virtuous and hold just as many high characteristics as any class in the country ....

... I am very much surprised at the gentleman from Kentucky [Mr. Beck] making these objections .... I had supposed that, having had an opportunity during the past summer to retum to the land that gave him birth, and to breathe the free atmosphere among the hills of Old Scotland, he would return to the land of his adoption with a generous spirit and open heart, ready to accord to the negro in this country the rights that belong to him as a citizen. But... he 
Representative Roger Q. Mills, Democrat of Texas, another opponent of the civil rights bill, described the origins of the Bill of Rights and asserted that "[t] hese first amendments and some provisions of the Constitution of like import embrace the 'privileges and immunities' of citizenship as set forth ... in the fourteenth amendment."298 Later in this speech, he stated that such privileges included,

among others, the right to the enjoyment of life, liberty, property ...; the right of peaceable assemblage ... ; freedom of speech, of the press, and of religion; immunity of one's person, house, and papers against unlawful seizure and search; trial by jury when held to answer for crime; to be informed of the accusation, and confronted with the accusers; immunity from excessive bail, excessive fines, and cruel and unusual punishments, and many others, all of which are recognized and guaranteed in the Constitution. ${ }^{299}$

Having thus touched upon, in an avowedly nonexhaustive list, rights conferred by the First, Fourth, Fifth, Sixth, and Eighth Amendments, Mills concluded that the states were "impotent ... to abridge" the "[c]itizenship under the Constitution" encompassing such "rights, privileges, and immunities." $300 \mathrm{He}$ did not specifically cite Slaughter-House, but he did state that "[f]rom the authority of adjudged cases it is clear that the privileges and immunities mentioned in the fourteenth amendment are only such as are conferred by the Constitution itself,"301 a close paraphrase of Justice Miller's definition of "privileges and immunities ... which owe their existence to the Federal ... Constitution." 302

That Slaughter-House was one of the "adjudged cases" to which Mills referred seems almost certain, given its prominent and repeated mention in the debates. In addition to Representative Beck's lengthy discussion of it a few weeks earlier, Democratic Representatives John T. Harris of Virginia and Alexander H. Stephens of Georgia, siding with Beck and Mills in opposition to the civil rights bill, discussed and quoted Slaughter-House at equally great length earlier on the

comes back with the same deep-rooted prejudice against the race to which I belong, and stands up here to-day and declares that if we be permitted to enter free schools or the public institutions in this country it can only be by the power of the bayonet, because it would create insurrection and rebellion in the Southem States.

Id. at 344 .

298 Id. at 384 ( $\operatorname{Tan} .5,1874)$.

299 Id. at 384-85.

${ }^{300}$ See id. at 385; see also id. at 415 (Jan. 6, 1874) (Rep. John M. Bright, D-Tenn., another civil rights bill opponent) ("What rights are now denied to the colored race? They have the freedom of the press, the freedom of speech, the freedom of the ballot, the freedom of office, the freedom of the courts, and the rights of property.").

301 Id. at 384 ( $\operatorname{Jan} .5,1874$ ).

302 Slaughter-House, 83 U.S. (16 Wall.) at 79. 
same day that Mills spoke. ${ }^{303}$ Harris and Stephens did not specifically address the incorporation issue, but nowhere in their extensive discussion of Slaughter-House did they dispute the incorporationist view of that decision advocated by their fellow Southern Democrats and civil rights bill opponents. The same appears to be true of the other members of Congress, both Democrats and Republicans, civil rights bill opponents and supporters, who discussed Slaughter-House (while not specifically addressing incorporation) in the course of these debates. ${ }^{304}$

Harris did declare that the Fourteenth Amendment "guarantees to the colored race, as to all others, the privileges and immunities of a citizen of the United States. The majority and minority of the court [in Slaughter-House] both concur in definition of these terms - that they mean 'the fundamental rights of life, liberty, and property." 305 Stephens referred in seeming approval (though again without expressly mentioning incorporation) to the speech "the other day by Mr. Beck, of Kentucky."306 Stephens suggested the weight that we might accord to the statements in these debates when he noted:

303 See 2 CONG. REC. 376 (Jan. 5, 1874) (Rep. Harris); id. at 378, 380 (Jan. 5, 1874) (Rep. Stephens).

304 See id. at 405-06 (Jan. 6, 1874) (Rep. Milton J. Durham, D-Ky., civil rights bill opponent, discussing and quoting at length from Slaughter-House); id. at 407-10 (Jan. 6, 1874) (Rep. Robert B. Elliott, R-S.C., civil rights bill supporter, discussing and quoting at length from Slaughter-House); id. at 414 (Jan. 6, 1874) (Rep. William Lawrence, R-Ohio, civil rights bill supporter, referring briefly to Slaughter-House); id. at 415 (Jan. 6, 1874) (Rep. John M. Bright, D-Tenn., civil rights bill opponent, discussing and quoting at length from Slaughter-House); id. at 416-17 (Jan. 6, 1874) (Rep. Josiah T. Walls, R-Fla., civil rights bill supporter, briefly discussing Slaughter-House); id. at 742 (Jan. 17, 1874) (Rep. Robert Hamilton, D-N.J., civil rights bill opponent, quoting at length from Slaughter-House); id. at 4085-88 (May 20, 1874) (Sen. Allen G. Thurman, D-Ohio, civil rights bill opponent, discussing and quoting at length from Slaughter-House). As Professor Maltz has noted, Sen. Thurman had embraced an incorporationist view of the Privileges and Immunities Clause before Slaughter-House was decided, in an earlier debate on the civil rights bill. See Maltz, Concept, supra note 52, at 526 (citing CONG. GLOBE, 42d Cong., 2d Sess. app 25-26 (1872)).

3052 CONG. REC. 376 (Jan. 5, 1874) (emphasis added). It was obviously an overstatement for Harris to suggest that the Slaughter-House majority and dissenters fully concurred in defining such privileges and immunities, but his comment suggests a common understanding that they did at least concur with regard to some important set of rights, most likely those set forth in the Bill of Rights. Incidentally, the racial tensions crackling through these debates surfaced again when Harris, in the heat of argument, asserted that "there is not one gentleman upon this floor who can honestly say he really believes that the colored man is created his equal." Rep. Alonzo J. Ransier (R-S.C.) interjected, "I can," to which an obviously flustered and angry Harris retorted, "Of course you can; but I am speaking to the white men of the House; and, Mr. Speaker, I do not wish to be interrupted again by him." Id.

${ }^{306}$ Id. at 378 (Jan. 5, 1874). 
I feel the necessity of the greatest possible care in duly considering and properly weighing every word that may be uttered by me in the discharge of the high duty now resting upon me, that there may be no misunderstanding of what I may say, and no grounds for any erroneous report or misrepresentation ... 307

Representative William S. Herndon, another Texas Democrat and opponent of the civil rights bill, joined Beck and Mills in embracing an incorporationist reading of the Fourteenth Amendment, and he did so on the basis of an extensive analysis of Slaughter-House. 308 Herndon concluded that the "rights, privileges, and immunities ... that appertain to the citizen of the United States ... may be found in the Constitution, amendments, and treaties with foreign nations." $309 \mathrm{He}$ "mention[ed] a few of them," including "[t]he right of habeas corpus, trial by jury, free exercise of religious worship, free speech, free press, to assemble and discuss public measures, to petition for redress, security against unreasonable searches and seizures, [and] ... to have counsel." 310

Senator Thomas M. Norwood, Democrat of Georgia, yet another civil rights bill opponent, set forth the most thorough argument in favor of total incorporation. He devoted most of five pages of double-column, small-print text in the Congressional Record to an exhaustive discussion of Slaughter-House and its interpretation of the Privileges and Immunities Clause. ${ }^{311}$ Norwood read the

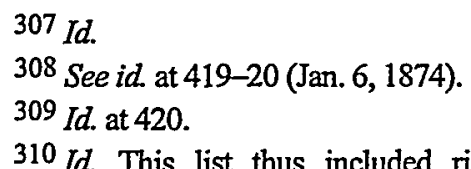

310 Id. This list thus included rights guaranteed by the First, Fourth, and Sixth Amendments, as well as by Article I, Section 9, Clause 2 of the Constitution, including all three constitutional rights (habeas corpus, assembly, and petition) mentioned by Justice Miller's majority opinion in Slaughter-House as within the scope of the Privileges and Immunity Clause. See supra Part II.C; see also 2 CONG. REC. app. 2 (Jan. 7, 1874) (Rep. Milton I. Southard, D-Ohio, civil rights bill opponent, citing and relying upon Slaughter-House to contend that "[i]t is thus made perfectly clear that the privileges and immunities mentioned in the fourteenth amendment are such only as are derived from the Constitution of the United States").

311 See 2 CONG. REC. app. 239-44 (Apr. 30 \& May 4, 1874). The depth of Norwood's racial bigotry was demonstrated earlier in the same speech when he ridiculed AfricanAmerican members of Congress who had spoken in favor of the civil rights bill:

[W] henever a democrat in the other wing of this Capitol thrusts his spear in the side of this hollow horse, the republicans stuff at once and set upon his legs some son of Ham to reply, and the republican press the following day regale the whole country with full particulars of the native, cannibalistic act by which the democrat, in the space of five minutes, was tom in pieces, devoured, and digested by his voracious adversary.

Id. at app. 235. Like Rep. Beck, see supra note 297, Sen. Norwood raised the specter of interracial marriage, which he assailed as "repugnant," "loathsome," and "unnatural," see 2 CONG. REC. app. 236-37 (Apr. 30 \& May 4, 1874). Most grotesquely, he mocked the sacrifice 
Slaughter-House majority opinion to support including within that Clause's protection the entire Bill of Rights, and he took care to list almost every single one of the guarantees mentioned in the first eight amendments, as well as several set forth in the original Constitution. 312

Perhaps most strikingly, Senator Norwood carefully criticized and refuted Justice Field's erroneous dissenting contention that the Slaughter-House majority's construction of the Clause rendered it "vain and idle" because the supremacy of federal law supposedly already protected such rights against state invasion. ${ }^{313}$ Norwood conceded that it was true, in a sense, that "no new privileges were conferred" by the Clause; rather, "[i]t has declared, simply, that

of the many African-American soldiers who had died in battle during the Civil War, sarcastically describing one engagement in which over five hundred soldiers perished, declaring that their White commander,

so long as his surviving colored companions would vote to make him govemor of Massachusetts or a Representative in Congress,... would spasmodically devote the idle moments of the remainder of his political and official life, in a feeble effort to secure to them the great constitutional right to attend "without distinction of race, color, or previous condition of servitude" every theater, circus, and menagerie in the United States of America and the Territories thereof.

Id. at app. 235-36. This was a response to the "eloquent account" by Rep. Butler, the commander in that engagement who later managed the civil rights bill in the House,

of how the wartime conduct of black soldiers had tempered his own racial prejudices.... "As I looked on their bronzed faces upturned in the shining sun to heaven as if in mute appeal against the wrong of the country for which they had given their lives... feeling I had wronged them in the past...I swore to myself a solemn oath ... to defend the rights of these men who have given their blood for me and my country...."

FONER, supra note 88, at 533 (quoting 2 CONG. REC. 458 (Jan. 7, 1874)); see also 2 CONG. REC. 340 (Dec. 19, 1873) (Rep. Butler).

312 See 2 CONG. REC. app. 241 (Apr. 30 \& May 4, 1874). Of the twenty-four separate privileges and immunities that may be parsed from the Bill of Rights, see supra note 90, Norwood listed at least twenty-three, the only arguable omission being the Seventh Amendment right to civil jury trial. However, he referred generally to "trial by jury" as one item on his list (separately listing, for example, the right "to trial in the State and district wherein the alleged crime shall have been committed"), which may indicate that he intended the general reference to encompass both criminal and civil jury trial. He also listed, for example, the right of habeas corpus, see U.S. CONST. art. I, $\S 9, \mathrm{cl} .2$, and immunity "from conviction of treason unless on the testimony of two witnesses to the same overt act, or on confession in open court," see id. art. III, $\S 3$, cl. 1. Norwood cautioned at the end of his list that "I do not assert that these are all the privileges and immunities of a citizen of the United States as distinguished from his rights as a citizen of a State, but I do say that any others, whether few or many, will be found enumerated in the Constitution of the United States." 2 CONG. REC. app. 241 (Apr. 30 \& May 4, 1874).

313 See id. at app. 242 (quoting Slaughter-House, 83 U.S. (16 Wall.) at 96 (Field, J., dissenting)); see also supra Part II.C. 
certain existing rights should not be abridged by States." 314 But since, as he noted, it had long been held that the first eight amendments, of their own force, limited only the federal government, the change worked by the Clause was dramatically important. "[T] hough new privileges were not thereby conferred, additional guarantees were." 315

In sum, Norwood declared, "the instant the fourteenth amendment became a part of the Constitution, every State was that moment disabled from making or enforcing any law which would deprive any citizen of a State of the benefits enjoyed by citizens of the United States under the first eight amendments to the Federal Constitution." 316 This was in 1874 from one of the most reactionary opponents of Reconstruction, in reliance upon a Supreme Court decision generally viewed as adopting the narrowest possible reading of the Privileges and Immunities Clause. Justice Black, the liberal avatar of total incorporation who saw the theory widely dismissed as implausibly radical in the next century, did not state it any better.

That Republican supporters of the civil rights bill continued to support (at the very least) an incorporationist reading of the Fourteenth Amendment is also suggested by these debates. For example, Representative William Lawrence, Republican of Ohio, recited the legislative history of the Amendment. He quoted Representative Bingham's 1866 statement that, while " $[$ t $]$ he enforcement of the bill of rights" had previously been left to " the reserved powers of the States, to be enforced by State tribunals and by State officials," Congress "should remedy that ... by amending the Constitution of the United States, expressly prohibiting the States from any such abuse of power in the future."'317 Lawrence also quoted Bingham's statement that a key purpose of the Amendment was "'to arm the Congress ... with the power to enforce the bill of rights."'318

3142 CONG. REC. app. 242 (Apr. 30 \& May 4, 1874).

315 Id.; see also CURTIS, NOSTATE, supra note 22, at 167-68.

3162 CONG. REC. app. 242 (Apr. 30 \& May 4, 1874).

317 Id. at 412 (Jan. 6, 1874) (quoting CONG. GloBE, 39th Cong., 1st Sess. 1291 (Mar. 9, 1866) (Rep. Bingham)) (emphasis added by Rep. Lawrence).

318 Id. at 413 (quoting CONG. GlOBE, 39th Cong., 1st Sess. 1088 (Feb. 28, 1866) (Rep. Bingham)) (emphasis added by Rep. Lawrence); see also id. at 409 (Jan. 6, 1874) (Rep. Robert B. Elliott, R-S.C., civil rights bill supporter) ("If [a state] abridges the rights of all her citizens equally, unless those rights are specially guarded by the Constitution of the United States, she does not violate [the Fourteenth] [A]mendment.") (emphasis added). Cf. SlaughterHouse, 83 U.S. (16 Wall.) at 96 (Field, J., dissenting) (criticizing majority for protecting only, inter alia, "privileges and immunities... specially designated in the Constitution"). Rep. Lawrence was a lawyer and former Ohio state judge, who received but declined an appointment as federal district judge in 1863. A member of Congress from 1865 to 1871 and again from 1873 to 1877, he was Chairman of the Committee on War Claims from 1873 to 1875, and later became Comptroller of the U.S. Treasury from 1880 to 1885 . See BIOGRAPHICAL DICTIONARY OF THE AMERICAN CONGRESS: 1774-1996, at 1373 (1997) 
Who were these intriguing Southern Democrats of 1873-74? How influential were they? At the time of these debates they were in the minority of a Republican-controlled Congress. ${ }^{319}$ But they appear to have been a respected and accomplished group, some of whom attained positions of leadership. Their outspoken role in the civil rights bill debate, as just described, provides some evidence of their prominence. They were all lawyers. ${ }^{320}$ Representative Stephens was the former Vice-President of the Confederacy. ${ }^{321}$ Representative Beck, who served in the House from 1867 to 1875, was elected to the Senate in 1876 . He was reelected twice and served until his death in 1890, becoming Chairman of the Senate Committee on Transportation Routes to the Seaboard during 1879-81. ${ }^{322}$ Representative Mills served in the House from 1873 to 1892, when he also was elected to the Senate, serving there until 1899. He was Chairman of the House Ways and Means Committee in 1887-89, and of the House Committee on Interstate and Foreign Commerce in 1891-92.323 Representative Harris, who

[hereinafter BIO. DicT. CONG.]. Rep. Elliott was one of the most distinguished AfricanAmericans in Congress. Also a lawyer, he served in Congress from 1871 to 1874, when he resigned to run for the South Carolina State House of Representatives, where he served from 1868 to 1870 and again from 1874 to 1876 , eventually becoming Speaker of the State House of Representatives. He also served as Attorney General of South Carolina from 1876 to 1877. Id. at 992. Sen. John Sherman (R-Ohio), speaking in favor of the civil rights bill before SlaughterHouse was decided, also endorsed an incorporationist reading of the Amendment. See CONG. GLOBE, 42d Cong., 2d Sess. 843-44 (Feb. 6, 1872). Indeed, he indicated that in his view the early "amendments to the Constitution do not define all of the rights of American citizens. They define some of them .... What are those rights? Sir, they are as innumerable as the sands of the sea." Id. at 843. Ironically, Berger cited Sherman as one whose views militated against a broad, incorporationist understanding of the Fourteenth Amendment. See BERGER, FOURTEENTH, supra note 60, at 40-41, 108-09.

319 In the 43d Congress of 1873-75, the Republicans held lopsided majorities of 203-88 in the House and 54-19 in the Senate. In the 1874 election, the Democrats swept to an almost equally lopsided 181-107 majority in the House, though the Republicans held the Senate until 1878. U.S. ELECTIONS, supra note 294, at 1344.

320 See Bio. DicT. CONG., supra note 318, at 638 (Rep. Beck); id. at 710 (Rep. Bright); id. at 973 (Rep. Durham); id. at 1167 (Rep. Harris); id. at 1205 (Rep. Hemdon); id. at 1528 (Rep. Mills); id. at 1596 (Sen. Norwood); id. at 1877-78 (Rep. Stephens). The Northem Democrats mentioned in the preceding text and footnotes were also all lawyers. See id. at 1150 (Rep. Hamilton); id. at 1858 (Rep. Southard); id. at 1947 (Sen. Thurman).

321 Id. at 1877-78; see also FONER, supra note 88, at 533. Reps. Hemdon and Mills both served in the Confederate Army. See BIO. DicT. Cong., supra note 318, at 1205, 1528. Rep. Stephens served in the House from 1843 to 1859 , and again from 1873 to 1882 , when he resigned to become Govemor of Georgia, in which office he died in 1883 . He was elected to the Senate in 1866, but could not take his seat because Georgia was not yet readmitted to Congress. In the House, he was Chairman of the Committees on Territories (1857-59) and Coinage, Weights, and Measures (1875-81). See id. at 1877-78.

322 See Bio. DicT. CONG., supra note 318, at 638. 
served in the House from 1859 to 1861 and 1871 to 1881 , was Chairman of the Committee on Elections in 1875-79, and of the Committee on Revision of the Laws in 1879-81.324

The incorporationist views of the Fourteenth Amendment and SlaughterHouse cited above were thus not stray remarks by nonentities. These views appear to have been uncontradicted during these debates, and are entitled to substantial weight in any assessment of the contemporary understanding of Slaughter-House.

\section{The Blaine Amendment Debates of 1876}

In August 1876, just a year after the enactment of the civil rights bill, Congress debated the so-called "Blaine Amendment," a constitutional amendment "proposed as a result of concern with the use of public funds for sectarian schools," which would have "prohibited states from establishing or interfering with free exercise of religion." 325 An argument pressed by antiincorporationist scholars is that if the First Amendment had been understood at the time as incorporated in the Fourteenth, the Blaine Amendment would have

323 See id. at 1528 . Sen. Norwood served in the Senate from 1871 to 1877 . Defeated for reelection, he returned to private law practice, hiring on as an advocate for California railroad magnate Collis Huntington. See id. at 1596; C. VANN WOODWARD, REUNION AND REACTION: THE COMPROMISE OF 1877 AND THE END OF RECONSTRUCTION 40, 251 (1951). He later served in the House from 1885 to 1889. See BIO. DiCT. CoNG., supra note 318, at 1596. Rep. Herndon served in the House from 1871 to 1875 . Defeated for reelection in 1874 , he resumed his private law practice. See id. at 1205 .

324 See id. at 1167 . Rep. Bright, see supra note 300 , served in the House from 1871 to 1881 and was Chairman of the Committees on Claims (1875-81) and Expenditures in the Department of the Treasury (1875-77). See BIO. DICT. CoNG., supra note 318, at 710. Rep. Durham, see supra note 304, served in the House from 1873 to 1879 and was Chairman of the Committee on Revision of the Laws (1875-77). He later served as Comptroller of the U.S. Treasury (1885-89). See BIO. DiCT. CoNG., supra note 318, at 973. Among the Northem Democrats cited, Rep. Southard, see supra note 310, served in the House from 1873 to 1879 and was Chairman of the Committee on Territories (1875-77). See BIO. DICT. CoNG., supra note 318 , at 1858 . Sen. Thurman, see supra note 304, served in the House (1845-47), on the Ohio Supreme Court (Associate Justice, 1851-54, and Chief Justice, 1854-56), and in the Senate (1869-81). In the Senate he was Chairman of the Committees on the Judiciary (187981) and Private Land Claims (1871-79), and served on the Electoral Commission that resolved the disputed Hayes-Tilden presidential election of 1876 . He became President Pro Tempore of the Senate in 1879-81 and was the unsuccessful Democratic nominee for Vice-President, on the ticket with President Grover Cleveland, in 1888. See BIO. DicT. CoNG., supra note 318, at 1947.

325 CURTIS, No STATE, supra note 22, at 169. 
been seen as redundant and unnecessary. ${ }^{326}$ In fact, as other scholars have pointed out, the proposal went considerably beyond the language of the First Amendment. ${ }^{327}$ This throws considerable doubt on whether the Blaine Amendment is really the ace-in-the-hole that some anti-incorporationists have argued. It does, however, pose something of a puzzle.

President Ulysses S. Grant, in his annual message to Congress in December 1875 , urged adoption of

a constitutional amendment... making it the duty of each of the several States to establish and forever maintain free public schools adequate to the education of all the children in the rudimentary branches within their respective limits, irrespective of sex, color, birthplace, or religions; forbidding the teaching in said schools of religious, atheistic, or pagan tenets; and prohibiting the granting of any school funds, or school taxes, or any part thereof, either by legislative, municipal, or other authority, for the benefit or in aid, directly or indirectly, of any religious sect or denomination, or in aid or for the benefit of any other object of any nature or kind whatever. ${ }^{328}$

A week later, Representative James G. Blaine, Republican of Maine and Speaker of the House from 1869 to 1875,329 proposed such an amendment in the House, as follows:

No State shall make any law respecting an establishment of religion or prohibiting the free exercise thereof; and no money raised by taxation in any State for the support of public schools, or derived from any public fund therefor, nor any public lands devoted thereto, shall ever be under the control of any religious sect, nor shall any money so raised or lands so devoted be divided between religious sects or denominations. 330

This proposal was not debated in the House until August 1876.331 The House debate shed no light on the incorporation issue, being concerned mainly with whether to add a provision (which the House did) stating that "[t]his article shall not vest, enlarge, or diminish legislative power in Congress."332

326 See, e.g., Berger, Nine-Lived Cat, supra note 62, at 464; see generally Alfred W. Meyer, The Blaine Amendment and the Bill of Rights, 64 HARV. L. REV. 939 (1951).

327 See AMAR, BIL OF RIGHTS, supra note 63, at 254-55 n.*; Kurt T. Lash, The Second Adoption of the Establishment Clause: The Rise of the Nonestablishment Principle, 27 ARIZ. ST. L.J. 1085, 1145-50 (1995).

3284 CONG. REC. 175 (Dec. 7, 1875).

329 See BIO. DiCT. CONG., supra note 318, at 669; supra note 319 (noting Republican loss of House majority in 1874 election, which of course deprived Blaine of the Speakership).

3304 CONG. REC. 205 (Dec. 14, 1875).

331 See id. at 5189-92 (Aug. 4, 1876).

332 Id. at 5189; see also id. at 5191-92 (House passage of amendment); id. at 5561 (Aug. 14, 1876) (Sen. Frederick T. Frelinghuysen, R-N.J.); Meyer, supra note 326, at 942. 
When the Senate took up the Blaine Amendment later that August, ${ }^{333}$ the version passed by the House was criticized by supporters for unduly restricting congressional power ${ }^{334}$ and for an apparent loophole that would have allowed states to fund religion through taxes not formally designated for public schools. 335 The Senate Judiciary Committee reported an amended version that was itself justly criticized for being even more poorly worded, and almost laughably prolix:

[Sec. 1.] No State shall make any law respecting an establishment of religion, or prohibiting the free exercise thereof; and no religious test shall ever be required as a qualification to any office or public trust under any State. No public property and no public revenue of, nor any loan of credit by or under the authority of, the United States, or any State, Territory, District, or municipal corporation, shall be appropriated to or made or used for the support of any school, educational or other institution under the control of any religious or anti-religious sect, organization, or denomination, or wherein the particular creed or tenets of any religious or anti-religious sect, organization, or denomination shall be taught. And no such particular creed or tenets shall be read or taught in any school or institution supported in whole or in part by such revenue or loan of credit; and no such appropriation or loan of credit shall be made to any religious or anti-religious sect, organization, or denomination, or to promote its interests or tenets. This article shall not be construed to prohibit the reading of the Bible in any school or institution; and it shall not have the effect to impair rights of property already vested.

Sec. 2. Congress shall have power, by appropriate legislation, to provide for the prevention and punishment of violations of this article. ${ }^{336}$

The primary complaint of the amendment's opponents was that it threatened, they argued, a federal legislative takeover of traditional state and local authority

333 See 4 CONG. REC. 5245-46 (Aug. 7, 1876); id. at 5453-57 (Aug. 11, 1876); id. at 5561-62, 5580-95 (Aug. 14, 1876).

334 See, e.g., id. at 5561-62 (Aug. 14, 1876) (Sen. Frelinghuysen).

335 See, e.g., id. at 5583-84 (Aug. 14, 1876) (Sen. Isaac P. Christiancy, R-Mich.); id. at 5594 (Aug. 14, 1876) (Sen. Oliver H.P.T. Morton, R-Ind.).

336 Id. at 5453 (Aug. 11, 1876). Sen. Lewis V. Bogy (D-Mo.) had fun ridiculing how "ambiguous, and wordy, and full of verbiage" the revised amendment was, with "so many disjunctive and conjunctive conjunctions and verbs and adverbs and passive cases and objective cases, all mixed promiscuously together, that ... by the time you have got through with it the idea that you had at the start has left you, vanished like a dream ...." Id. at 5590 (Aug. 14, 1876). Engaging in a joking colloquy with Sen. George F. Edmunds (R-Vt.), chairman of the Judiciary Committee and apparently the author of the revised draft, see id. at $5589-90$, Sen. Bogy said "my friend from Vermont put his pen to paper, he admits, [laughter,] after a good dinner. This is, indeed, very plain; yet it is not in accordance with the old maxim in vino veritas ...."Id. at 5590 (brackets in original). 
over education. ${ }^{337}$ Accusations were also bandied about that supporters were seeking to play on anti-Catholic sentiment for partisan advantage in that presidential election year. ${ }^{338}$ In the end, it fell narrowly short in the Senate of the two-thirds majority required for passage. 339

Although the introductory language of the Blaine Amendment tracked the First Amendment, the wide-ranging scope of the rest of it, and the arguably new restrictions it expressly imposed on the federal government as well as on the states, support the conclusion that "as a whole [it] was hardly redundant."340 Scholars have plausibly argued that "Blaine and others were cleverly trying to bundle their dubious new rules alongside a far more acceptable clause."341 As Professor Amar has suggested, the redundancy argument is not intrinsically compelling in any event: "[M]any of the provisions of the original Bill [of Rights] were seen as 'declaratory' of existing law . . . and thus in some sense redundantand this declaratory theory was one of the driving forces behind the Fourteenth Amendment."342

A dose of realpolitik bolsters this conclusion. Blaine was a perennial candidate for the Republican presidential nomination, starting in $1876 . .^{343}$ It is only realistic to presume that he intended to gain some political mileage from his proposed amendment. ${ }^{344} \mathrm{He}$ thus had every incentive to articulate a specific, catchy proposal for concrete congressional action, focusing on an issue generating public concern at the time. To argue that the Fourteenth Amendment - as part of a general embrace of the Bill of Rights-already barred the states from improperly funding religion, and should be so construed by courts,

337 See, e.g., id. at 5580 (Aug. 14, 1876) (Sen. Francis Kernan, D-N.Y.); id. at 5589 (Aug. 14, 1876) (Sen. John W. Stevenson, D-Ky.); id. at 5591 (Aug. 14, 1876) (Sen. Bogy).

338 See, e.g., id. at 5592-95 (Aug. 14, 1876) (remarks of various senators); see also Lash, supra note 327 , at 1145-50 (arguing that anti-Catholic animus, not any desire to extend nonestablishment principle, was true motivation behind Blaine Amendment).

3394 CONG. REC. 5595 (Aug. 14, 1876) (Senate voting 28-16 in favor, i.e., only two votes short of two thirds, with twenty-seven senators absent or paired).

340 AMAR, BILL OF RIGHTS, supra note 63, at $255 \mathrm{n}$.*

341 Id.; see also Lash, supra note 327, at 1145-50.

342 AMAR, BILL OF RigHTS, supra note 63, at $255 \mathrm{n} .{ }^{*}$.

343 See Richard N. CURRENT, T. HARRY WILlIAMS, FRANK FrEDEL \& ALAN BRINKLEY, AMERICAN HISTORY: A SURVEY 476, 569-74 (6th ed. 1983). Blaine gained the nomination in 1884, but lost narrowly to Democrat Grover Cleveland, tripped up in part by an anti-Catholic incident reminiscent of the Blaine Amendment debate, when a Protestant minister and supporter of Blaine, during a meeting with the candidate, embarrassed him by labeling the Democrats the party of "rum, Romanism, and rebellion." See id. at 572-74. Ironically, Blaine's own mother was a Catholic. Id. at 574.

344 See, e.g., 4 CONG. REC. 5592 (Aug. 14, 1876) (Sen. William W. Eaton, D-Conn.) ("This whole business originated with Hon. James G. Blaine. Did you ever hear of him? It was one of his dodges to get a nomination ....'); see generally Lash, supra note 327, at 1145-50. 
might have been more proper and sensible in a dry, lawyerly way, but would hardly have served political needs.

Nevertheless, it must be conceded that there was a curious silence regarding the Fourteenth Amendment during the Blaine Amendment debates. The charge of redundancy actually was leveled against the proposal, but only based on the existence of state constitutional provisions said to adequately guarantee religious liberty. 345 At several points in the debate, both supporters and opponents indicated, without any reference to the Fourteenth Amendment, an understanding that First Amendment guarantees were not binding on the states. ${ }^{346}$ It seems surprising to find such barren Barron orthodoxy just two years after the speeches of Senator Norwood and Representatives Beck, Mills, Herndon, and Lawrence described above, just four years after the 1871-72 debates mentioned in Part II.A, and just ten years after the famous speeches of Representative Bingham and Senator Howard.

What had become of those members of Congress who had explicitly embraced incorporation? Bingham, after two squeaker reelections in 1868 and 1870, was denied renomination in 1872 and appointed minister to Japan in 1873, rather effectively removing him from the fray. ${ }^{347}$ Howard died in 1871,348 and Beck and Herndon were gone from Congress by 1875.349 But Lawrence, Mills, and Norwood were still in Congress in 1876,350 as were Ohio Senators John Sherman and Allen G. Thurman. ${ }^{351}$ Sherman and Thurman, however, were

345 See, e.g., 4 CONG. REC. 5581 (Aug. 14, 1876) (Sen. Kernan); id. at 5591-92 (Aug. 14, 1876) (colloquy between Sens. Morton and Eaton).

346 See, e.g., id. at 5245 (Aug. 7, 1876) (Sen. Christiancy, supporter); id. at 5454 (Aug. 11, 1876) (Sen. Theodore F. Randolph, D-N.J., supporter of House version, but opponent of Senate version); id. at 5561 (Aug. 14, 1876) (Sen. Frelinghuysen, supporter); id. at 5583 (Aug. 14, 1876) (Sen. William P. Whyte, D-Md., opponent); id. at 5595 (Aug. 14, 1876) (pairing of senators and Senate roll-call vote); see also id. at 5191 (Aug. 4, 1876) (Rep. Nathaniel P. Banks, D-Mass., supporter) (stating that amendment would "prohibi[t] the States from exercising the power they now exercise"); id. at 5191-92 (Aug. 4, 1876) (House roll-call vote).

347 See U.S. ElECTIONS, supra note 294, at 1019 (reelected by $51-49 \%$ in 1868); id. at 1022 (same in 1870); 2 AMERICAN NATIONAL BIOGRAPHY 792-93 (1999) [hereinafter AM. NAT'L BIO.] (entry by Dean Richard L. Aynes). Bingham was denied renomination "because of constituents' belief that the seat should be rotated among people from other counties in his district." 2 AM. NAT'L BIO., supra, at 792. He served in Japan until 1885 and died in Ohio in 1900. Id. at 793.

348 See U.S. ELECTIONS, supra note 294, at 796 (left Senate on Mar. 3, 1871); Fairman, supra note 22, at $134 \mathrm{n} .381$ (died on Apr. 2, 1871).

349 See Bro. DiCT. CONG., supra note 318 , at 638,1205 . Beck returned to Congress after his election to the Senate in 1876, as noted earlier. See id. at 638.

350 See id. at $1373,1528,1596$.

351 See supra notes 304 and 318 (noting support of incorporation, prior to SlaughterHouse, of both Thurman and Sherman); BIO. DiCT. CONG., supra note 318, at 1815 (Sherman 
absent during the Blaine Amendment debate. ${ }^{352}$ Norwood, who voted against the version before the Senate, did not speak. ${ }^{353}$ Mills, who joined the overwhelming House majority in voting for the version before that body, was also silent. 354 Lawrence, who strongly supported the amendment, gave one of the longest speeches on it of any member of the House during the brief debate in that body, but said nothing shedding any light on the First or Fourteenth Amendments or incorporation. 355

\section{Cooley's Views}

What could account for the foregoing shift in congressional sentiment on, or at least attention to, the incorporation issue? Light may be shed by further research on what contemporary lawyers outside Congress understood regarding the incorporationist implications of Slaughter-House. This author has not yet had the opportunity to undertake such research, but a review of contemporary treatises by Thomas M. Cooley fails to support the incorporationist reading of Slaughter-House. On the other hand, that may have little significance, since Cooley said very little at all about Slaughter-House or the incorporation issue.

Cooley, who served as Chief Justice on the Michigan Supreme Court and Professor of Law at the University of Michigan, was perhaps the most prestigious American legal scholar of the time. ${ }^{356} \mathrm{He}$ was politically a Republican and his legal philosophy has been described as pragmatic and conservative. ${ }^{357}$ The first

in Senate, 1861-77 and 1881-97, Secretary of the Treasury, 1877-81, and Secretary of State, 1897-98); id. at 1947 (Thurman in Senate, 1869-81). It is interesting that Bingham's home state of Ohio also elected, as both of its Reconstruction-Era senators, two such politically distinctive supporters of incorporation as Democrat Thurman, civil rights bill opponent, and Republican Sherman, civil rights bill supporter. Sen. Howard, of course, was from next-door Michigan. I thus find it satisfying and appropriate, having grown up in Michigan myself, that this article and its sequel, see supra note 4, are being published in the Ohio State Law Journal.

352 See 4 CONG. REC. 5456-57 (Aug. 11, 1876) (Sherman and Thurman absent from rollcall votes); id. at 5595 (Aug. 14, 1876) (same). See generally id. at 5245-46 (Aug. 7, 1876) (Senate debate); id. at 5453-57 (Aug. 11, 1876) (same); id. at 5561-62, 5580-95 (Aug. 14, 1876) (same).

353 See id. at 5245-46, 5453-57, 5561-62, 5580-95. Every Democratic senator who voted opposed the amendment. See id. at 5595; Lash, supra note 327, at 1150 n.288; supra note 339.

354 See 4 CONG. REC. 5189-92 (Aug. 4, 1876) (House debate); id. at 5191-92 (House voting $180-7$ in favor, with 98 not voting).

355 See id. at 5190-91.

356 See generally Paul D. Carrington, Law as "The Common Thoughts of Men": The Law-Teaching and Judging of Thomas McIntyre Cooley, 49 STAN. L. REV. 495 (1997).

357 See id. at 518, 528-31. Cf. id. at 545 (noting that despite Cooley's party affiliation, he supported successful Democratic presidential candidate Grover Cleveland in 1884 election, 
edition of Cooley's treatise Constitutional Limitations, published in 1868, did not discuss the newly ratified Fourteenth Amendment. ${ }^{358}$ The second edition, published in 1871, appeared to assume that the Bill of Rights remained nonbinding on the states but did not offer any substantial discussion of the incorporation issue. Cooley's view seemed to be based on the long-established Barron doctrine, with little consideration of the impact of the Fourteenth Amendment. 359

apparently because of concerns over ethics of Republican nominee James G. Blaine, see supra note 343 ).

358 See THOMAS M. COOLEY, A TREATISE ON THE CONSTITUTIONAL LIMITATIONS WHICH REST UPON THE LEGISLATIVE POWER OF THE STATES OF THE AMERICAN UNION (1868) [hereinafter COOLEY, CONSTITUTIONAL LIMTATIONS 1868; titles of later editions abbreviated to "CONSTITUTIONAL LIMTATIONS"]. This edition appeared in September 1868, following the Amendment's ratification in July 1868, but had probably been completed before ratification. See Aynes, Bingham, supra note 54, at 91.

359 See Thomas M. COOLEy, CONSTTIUTIONAL LimtTations *19 n.l (2d ed. 1871) [hereinafter COOLEY, CONSTITUTIONAL LIMTATIIONS 1871] (citing Barron, pre-1868 cases following Barron, and Twitchell, without mentioning Fourteenth Amendment, and stating that "though the right of trial by jury is preserved by the Constitution...., the States may, nevertheless, if they choose, provide for the trial of all offences against the States, as well as the trial of civil cases in the State courts, without the intervention of a jury"); see also supra Part II.A (discussing Barron and Twitchell). Dean Aynes argued that this treatise can be read to support incorporation. Aynes overlooked the passage just quoted, while citing two other passages. See Aynes, Bingham, supra note 54, at 91-92 \& nn.228-229 (citing COOLEY, CONSTIIUTIONAL LIMITATIONS 1871 , supra, at *294,*397). In the first of these, Cooley stated that it was

doubtful whether the ... provisions [other than the Citizenship Clause] of the [first] section [of the Amendment] surround the citizen with any protections additional to those before possessed under the State constitutions; but as a principle of State constitutional law has now been made a part of the Constitution of the United States, the effect will be to make the Supreme Court of the United States the final arbiter of cases in which a violation of this principle by State laws is complained of....

COOLEY, CONSTITUTIONAL LIMTATIONS 1871, supra, at *294. As Aynes noted, "[i]f Cooley viewed the federal Bill of Rights as protecting the same rights as state constitutions ...., then his 1871 Fourteenth Amendment views contradict Fairman's and coincide with those of Bingham." Aynes, Bingham, supra note 54, at 92 . On the other hand, Cooley may simply have been referring to the fact that most states already guaranteed "due process" and some undefined set of "privileges and immunities" in their state constitutions; he did not define the "principle of State constitutional law" to which he referred. The other passage cited by Aynes referred merely to the interstate equality aspect of both the Article IV and Fourteenth Amendment Privileges and Immunities Clauses, stating that

[a] though the precise meaning of 'privileges and immunities' is not very definitely settled as yet, it appears to be conceded that the Constitution secures in each State to the citizens of all other States the right to remove to, and carry on business therein; the right ... to acquire and 
When Slaughter-House was decided in April 1873, Chief Justice Cooley's revised fourth edition of Justice Joseph Story's famous Commentaries on the Constitution, in which Cooley authored a new chapter on the Fourteenth Amendment, was just going to press. ${ }^{360}$ Cooley explained that there was no time to incorporate any discussion of the decision into the main text, so he just reprinted much of Justice Miller's opinion in an appendix, introduced by the comment that his views were "fortunately in harmony with" it. ${ }^{361}$ His views, as stated in the main text, had reiterated the nonapplicability of the Bill of Rights to the states. 362

In December 1873, just prior to the debates discussed in Part III.A.1, Chief Justice Cooley completed the third edition of Constitutional Limitations, which

hold property, and to protect and defend the same in the law; [and] the right to...the enforcement of other personal rights....

COOLEY, CONSTITUTIONAL LIMTTATIONS 1871, supra, at *397. Cf. Aynes, Bingham, supra note 54, at 92 (mistakenly reading this passage to imply support for substantive incorporation of "personal rights").

360 See 2 JOSEPH STORY, COMMENTARIES ON THE CONSTITUTION OF THE UNITED STATES 648-85 (4th ed., Thomas M. Cooley, ed., 1873) [hereinafter COOLEY ON STORY 1873] (ch. XLVII, "The Fourteenth Amendment"); id. at 693 (noting the Slaughter-House decision was handed down "[w]hile the last of the foregoing sheets were passing through the press").

361 Id. at 693; see also id. at 693-703 (quoting at length Miller's opinion, including his reference to rights of assembly, petition, and habeas corpus as privileges or immunities of United States citizens).

362 See id. $\$ 1947$, at 665-66. Cooley stated, in discussing the Fourteenth Amendment Due Process Clause, that

earlier amendments to the Constitution provide certain safeguards in criminal cases, ... among other things a presentment by grand jury... in the case of capital or other infamous crimes. But those amendments apply only to such offences as may be taken cognizance of and punished by the federal government, and not at all to those which are offences only against... the several States. The States... may dispense with the grand jury...; and they may make all State offences triable before a single judge, instead of by jury....

Id. In discussing the Privileges and Immunities Clause, he defined the privileges of state citizenship broadly to include the rights "to be protected in life and liberty by the law" and "to acquire, possess, and enjoy property." Id. § 1934, at 656. He emphasized that the Clause protected only the privileges and immunities of United States citizens as such and that "[t]he difference is in a high degree important." Id. $\S 1937$, at 658. He stated that "it is a consideration of the sphere of the [state and federal] governments respectively which suggests the rights and privileges as citizens of those entitled to their protection," and proceeded to list several privileges identical or strikingly similar to the redundant items on Miller's Slaughter-House list (e.g., "right to demand protection against the wrongful action of foreign authorities" and "to make use in common with all others of the navigable waters of the United States"). Id. at 659. "It would be useless to attempt a general enumeration, but these few may suffice as illustrations, and will suggest others." Id. 
appeared in 1874.363 The key passages bearing on incorporation were unchanged from the 1871 edition, suggesting either inattention or that Cooley did not view Slaughter-House as affecting the issue ${ }^{364}$-which, of course, the decision (as opposed to the dicta) did not. In fact, Cooley made remarkably few references to Slaughter-House at all, and those few, quite understandably, addressed not implications in the dicta but rather the specific holding on the disputed monopoly. 365

363 See THOMAS M. COOLEY, CONSTIIUTIONAL LIMTTATIONS iv (3d ed. 1874) [hereinafter COOLEY, CONSTITUTIONAL LIMTATIONS 1874] (preface dated Dec. 1873).

364 Compare id. at *19 n.1, *294, *397 with COOLEY, CONSTITUTIONAL LIMITATIONS 1871 , supra note 359 , at *19 n.1, *294, *397. See supra note 359 . The 1874 edition noted in a footnote to the second of these passages that "[the Fourteenth Amendment] received a very careful examination at the hands of the Supreme Court of the United States in the recent case of [Slaughter-House], not yet reported." COOLEY, CONSTITUTIONAL LIMTATIONS 1874, supra note 363 , at $* 294$ n.2.

365 See COOLEY, CONSTITUTIONAL LIMITATIONS 1874, supra note 363, at xxxix (index entry for Slaughter-House, cited as "Live Stock, \&c., Association v. Crescent City, \&c., Co."); id. at *11 n.1 (noting that Reconstruction Amendments were "construed in the recent [Slaughter-House] cases," with no further discussion); id. at *294 n.2 (noting that Fourteenth Amendment "received a very careful examination at the hands of the Supreme Court" in Slaughter-House, with no further discussion). In a passage dealing with the general police powers of the states, Cooley stated that "the national government... [cannot] assume any supervision of the police regulations of the States, so long as they do not invade the sphere of national sovereignty, and obstruct or impede the exercise of any authority which the constitution has confided to the nation." Id. at *574. In a footnote to this sentence, he noted that a "claim has recently been advanced at New Orleans" that the federal courts had authority, "at the suit of citizens of a State, to review one of its statutes purporting to establish a police regulation, and to adjudge it void if in their opinion it wrongfully abridged the right of citizens to follow a lawful employment; but this claim has not been sustained." Id. at *574 n.3 (citing Slaughter-House); see also id. at *584-85 n.2 ("As to the power of the public authorities to establish a public slaughter-house, or to require all slaughtering of beasts to be done at one establishment, see... [Slaughter-House].").

Dean Aynes read another 1874 treatise, by a different author, to support incorporation. See Aynes, Bingham, supra note 54, at 94 n.240 (quoting ISRAEL WARD ANDREWs, MANUAL OF THE CONSTITUTION OF THE UNITED STATES 274 (1874)). Andrews, however, in the quoted passage, merely noted that because "it has been maintained that the first eight Amendments had no reference to the State governments, but were restraints upon the general government only, this Fourteenth Amendment declares explicitly that 'No State shall [etc., quoting remainder of Section 1]." ANDREWS, supra, at 274. This merely pointed out that the Fourteenth Amendment was carefully drafted to apply to the states, and did not address the scope of the restrictions thereby imposed. Because Andrews quoted the entire second sentence of Section 1, including the Equal Protection Clause (which has no relevance to the incorporation issue), it seems a stretch to suppose that he intended any comment on that issue (which he did not otherwise address). He never discussed Slaughter-House; the book generally did not delve into detailed case analysis. 
It is worth noting that Chief Justice Cooley, more than a decade later, did express the view that at least the freedoms of speech, press, and assembly were incorporated into the Fourteenth Amendment, as part of the "liberty" protected by the Due Process Clause. ${ }^{366}$ But that has no bearing on his view of SlaughterHouse.

\section{Conclusion}

As suggested above, the 1873-74 congressional consensus on incorporation may be ascribable, in part, to the implications of Slaughter-House. The prevailing attitude in August 1876 may likewise be ascribable, in part, to three Supreme Court decisions between November 1874 and April 1876 which began to unravel the implicit compromise of Slaughter-House: Edwards v. Elliott, ${ }^{367}$ Walker $v$. Sauvinet, ${ }^{368}$ and United States v. Cruikshank ${ }^{369}$ These cases are discussed in Parts III.B and III.C. Professor Curtis suggested this explanation in citing the one significant comment on the Fourteenth Amendment that did appear throughout the entire Blaine Amendment debate. This was the argument by Senator Oliver H.P.T. Morton, Republican of Indiana, as to why the Blaine Amendment, especially the detailed Senate version, was in his view essential:

The fourteenth and fifteenth amendments which we supposed broad, ample, and specific, have, I fear, been very much impaired by construction, and one of them in some respects almost destroyed by construction. Therefore I would leave as little as possible to construction. I would make [the Blaine Amendment] so specific and so strong that [it] cannot be construed away and destroyed by courts. 370

${ }^{366}$ Cooley expressed this view in 1887, in private correspondence with British legal scholar (later British Ambassador to the United States) Dr. James Bryce, in the course of commenting upon drafts of Bryce's book, The American Commonwealth. See Everett S. Brown, The Contribution of Thomas M. Cooley to Bryce's "American Commonwealth," 31 MiCH. L. REV. 346, 352-53 (1933).

36788 U.S. (21 Wall.) 532 (1874).

36892 U.S. 90 (1876).

36992 U.S. 542 (1876).

3704 CONG. REC. 5585 (Aug. 14, 1876), quoted in CURTIS, No STATE, supra note 22, at 170. See generally CURTIS, No STATE, supra note 22, at 169-70 (explaining shit in congressional sentiment on basis of Cruikshank and Walker, though not discussing Edwards). It seems almost certain that Sen. Morton was referring, at least, to Cruikshank and its companion case, United States v. Reese, 92 U.S. 214 (1876) (both decided on Mar. 27, 1876), in light of his linked reference to the Fourteenth and Fifeenth Amendments. Cruikshank narrowly construed both Amendments, and Reese the Fifteenth. See KACZOROWSKI, POLITICS, supra note 88, at 213-17; infra Part III.C. 
That the Supreme Court was indeed both able and willing to "construe away" and "destroy" a central part of the Fourteenth Amendment is the lesson of the sorry but dramatic tale that follows.

\section{B. The Confusion in the Supreme Court, Part 1: Edwards and Walker}

In Edwards, decided on November 30,1874,371 the Court addressed a challenge to a New Jersey law concerning maritime debt recovery procedures. Nelson Edwards, a ship owner, argued before the Court, among many other issues, that the state law violated the right to civil jury trial set forth in the Seventh Amendment, which he argued (very briefly and without analysis) was a privilege or immunity protected by the Fourteenth Amendment. 372 George Elliott, a creditor who had "furnished timber for the vessel,"373 argued that Edwards had failed to raise this issue in the courts below. ${ }^{374}$ Referring to the Fourteenth Amendment claim as "an afterthought [that] needs no reply,"375 Elliott's attorney did briefly respond to it, but in a manner indicating that he had confused the Fourteenth Amendment and Article IV Privileges and Immunities Clauses. ${ }^{376}$

371 See Edwards, 88 U.S. (21 Wall.) 532; see also id., 22 L. Ed. at 487 (giving exact date of decision; for many nineteenth-century Supreme Court cases, the precise date of decision appears only in the Lawyers' Edition of the U.S. Supreme Court Reports).

372 Edwards also argued that he was deprived of due process of law and equal protection of the laws. See Edwards, 88 U.S. (21 Wall.) at 544 (summary of argument); Brief for Plaintiffs in Enor at 9, 15, Edwards v. Elliott, 88 U.S. (21 Wall.) 532 (1874) [hereinafter Edwards Plaintiffs' Brief]; see also Edwards, 88 U.S. (21 Wall.) at 534-35.

373 Edwards, 88 U.S. (21 Wall.) at 534.

${ }^{374}$ See Brief for Defendants in Error at 30, Edwards v. Elliott, 88 U.S. (21 Wall.) 532 (1874) [hereinatter Edwards Defendants' Brief].

375 Id. Elliott understandably complained that Edwards had done little more than vaguely suggest that the state law was "contrary, in some way not clearly pointed out, to the 14th amendment." Id.

376 Id. Elliott argued that the Fourteenth Amendment

did not profess to control the power of the State governments over the rights of its own citizens, but only to declare that as the States grant them to their own citizens, or as they limit or qualify, or impose restrictions on their exercise, the same, neither more nor less, shall be the measure of the rights of citizens of other States within their jurisdiction.

Id. (citing Slaughter-House, 83 U.S. (16 Wall.) at 77). This, of course, merely restated the orthodox interstate equality reading of the Article IV Clause and had nothing properly to do with the Fourteenth Amendment Clause. See supra Part II.B. On the cited page of SlaughterHouse, Justice Miller offered an almost identical description of the purpose of the Article IV Clause. Elliott also cited Slaughter-House for Miller's general caution against "constitut[ing] this Court a perpetual censor upon all legislation of the States," Slaughter-House, 83 U.S. (16 Wall.) at 78, and suggested that no one should "attempt a similar application of the limitations of the national constitution to the laws and proceedings" of any state. See Edwards Defendants' 
The parties' briefs, and the Court's unanimous opinion by Justice Clifford, were concerned almost entirely with issues of admiralty and maritime law completely unrelated to jury trial, incorporation, or the Fourteenth Amendment. 377

In a brief passage at the end of his opinion, Justice Clifford agreed with Elliott that the jury trial issue had not been properly raised below and was thus not properly before it. Clifford described Edwards as claiming that the state law was "in conflict with the provision of the Federal Constitution which secures to every party, where the value in controversy exceeds twenty dollars, the right of trial by jury," 378 an apparent reference to the Seventh Amendment alone. Clifford then stated:

Two answers may be made to that objection, either of which is decisive: (1.) That it does not apply to trials in the State courts. (2.) That no such error was assigned in the [New Jersey] Court of Errors, and that the question was not presented to, nor was it decided by, the Court of Errors.

Jurisdiction is not shown unless it appears that some one of the specified questions did arise in the State court and that the question was decided adversely to the party assigning error in this court. ${ }^{379}$

That was it. Clifford supported the critical first point with a footnote citing Barron, Twitchell, three pre-1868 cases following Barron, and the 1871 edition of Chief Justice Cooley's Constitutional Limitations. ${ }^{380}$

Justice Clifford never even mentioned, let alone analyzed, the Fourteenth Amendment. That it was raised at all is apparent only from a careful reading of the briefs and the summary of argument in the case report, ${ }^{381}$ which may account for the fact that Walker, not Edwards, is usually cited as the case establishing that

Brief, supra note 374, at 30; see also Edwards, 88 U.S. (21 Wall.) at 548-49 (summary of argument).

377 See generally Edwards, 88 U.S. (21 Wall.) at 549-57; Edwards Plaintiffs' Brief, supra note 372, at 1-10, 16-46; Edwards Defendants' Brief, supra note 374, at 1-29.

378 Edwards, 88 U.S. (21 Wall.) at 557.

${ }^{379} \mathrm{Id}$. at 557-58 (citation omitted).

380 See id. at 557 n.30; see also supra Part II.A (discussing 1869 Twitchell decision, in which Fourteenth Amendment was not raised, and which itself merely relied on Barron). The Court cited COOLEY, CONSTITUTIONAL LIMTATIONS 1871, supra note 359 , at *19, a passage in which Cooley himself, as discussed in Part III.A.3, merely relied upon Barron, Twitchell, and pre-1868 cases following Barron, without mentioning the Fourteenth Amendment. See supra note 359 .

381 See Edwards Plaintiffs' Brief, supra note 372, at 9, 15; Edwards Defendants' Brief, supra note 374, at 30; see also Edwards, 88 U.S. (21 Wall.) at 544 (summary of Edwards's argument); id. at 548-49 (summary of Elliott's argument). 
the Fourteenth Amendment does not incorporate the right to civil jury trial. ${ }^{382}$ Clifford's failure to address the Fourteenth Amendment and his reliance on Barron and other pre-1868 cases strongly suggest that he was not even thinking of the incorporation issue. If Clifford did, perchance, consciously intend to scupper the idea of incorporation, we would be entitled to suspect his motives in thereby "pulling a fast one" on his colleagues and the country. Clifford's possible hostility to any broad reading of the Fourteenth Amendment, even a reading widely supported on the merits, may be inferred from the fact that he was a "proslavery Democrat" whose pre-Civil War appointment to the Court by President James Buchanan had stirred bitter protest. ${ }^{383}$

Given the minor significance of the jury trial issue in the overall context of the case, there is no reason to suppose that the other Justices thought they were deciding such an important issue as incorporation of the Bill of Rights. Justice Clifford's alternative reliance on the failure of Edwards to properly preserve the jury issue rendered the Court's ipse dixit little more than needless dicta, though strictly speaking it was part of the holding. What makes the implicit denial of incorporation in Edwards even more frustratingly gratuitous and inappropriate is that it had long been established, and remains the general rule today, that the Seventh Amendment right to civil jury trial does not apply in civil admiralty cases in any event. 384

Nevertheless, a year and a half after Edwards, the Court unambiguously confirmed that the Fourteenth Amendment did not require the states to respect the civil jury trial guarantee of the Seventh Amendment. Walker $v$. Sauvinet, ${ }^{385}$ decided on April 24, 1876,386 arose, like Slaughter-House, from Louisiana, and apparently even involved two of the same attomeys. ${ }^{387}$ The facts were loaded

382 See, e.g., CURTIS, No STATE, supra note 22, at 170, 179-80 (discussing Walker without mentioning Edwards); Morrison, supra note 6, at 145 (same).

383 See Aynes, Miller, supra note 41, at 665-66 (quoting PHILIP CLIFFORD, NATHAN CLIFFORD, DEMOCRAT 25 (1992)); OXFORD SUPREME COURT, supra note 39, at 967.

384 See 2 THOMAS J. SCHOENBAUM, ADMIRALTY AND MARTTME LAW $\S 21-9$, at 510 (2d ed. 1994); see also Fed. R. Civ. P. 38(e).

38592 U.S. 90 (1876).

${ }^{386}$ Id., 23 L. Ed. at 678 (giving exact date of decision).

387 Thomas J. Durant, one of the attomeys for the defendants in Slaughter-House, see supra note 253, was apparently one of the attorneys who represented Walker, the (presumably White) coffee-house owner who was the defendant at trial and the plaintiff in error (i.e., the appellant) before the Supreme Court. See Walker, 92 U.S. at 92 (indicating that C.W. Homor argued Walker's case before the Court); 23 L. Ed. at 678 (indicating "T.J. Durant" along with Hornor as counsel for Walker); Brief for Plaintiff in Error at 4, Walker v. Sauvinet, 92 U.S. 90 (1876) [hereinafter Walker Brief] (indicating "Durant \& Homor" as authors of brief). J.Q.A. Fellows, one of the attomeys for the White butchers (plaintiffs) in Slaughter-House, see supra note 246, represented Sauvinet, the African-American plaintiff at trial and the defendant in error (i.e., the appellee) before the Supreme Court. See Walker, 92 U.S. at 92 (indicating 
with Reconstruction-Era racial overtones. Charles Sauvinet, the AfricanAmerican Sheriff of Orleans Parish, sued Joseph Walker, the owner of a New Orleans coffee-house, for "refusing [Sauvinet] refreshments when called for, on the ground that [Sauvinet] was a man of color." 388 This violated a Louisiana state civil rights law, and Sauvinet won a judgment from a state judge, in accordance with Louisiana law, after a hung jury failed to reach a verdict. 389

The Court's brief opinion, by Chief Justice Morrison R. Waite, stated that "[s]o far as we can discover from the record, the only Federal question" at issue was whether Walker had been unconstitutionally denied the right to trial by jury. ${ }^{390}$ The Court then proceeded to resolve whether Louisiana had violated the Privileges and Immunities or Due Process Clauses of the Fourteenth Amendment in this regard, and concluded that it had not because such a right did not apply to the states under those Clauses. ${ }^{391}$ But the Court's reasoning was, at best, a cursory non sequitur.

Although the Walker Court, unlike Edwards, at least dignified the Fourteenth Amendment by mentioning it, Chief Justice Waite began by focusing on whether the Seventh Amendment itself guaranteed civil jury trial in state courts. Of course, the Court quickly noted, "as has been many times decided, [the Seventh Amendment] relates only to trials in the courts of the United States," citing Edwards, ${ }^{392}$ which, as we have seen, relied on Barron and other pre-1868 cases.

The States, so far as th[e] [Seventh] [A]mendment is concerned, are left to regulate trials in their own courts in their own way. A trial by jury in suits at common law pending in the State courts is not, therefore, a privilege or immunity of national citizenship, which the States are forbidden by the Fourteenth Amendment to abridge. ${ }^{393}$

Fellows argued Sauvinet's case); Brief for Defendant in Error at 5, Walker v. Sauvinet, 92 U.S. 90 (1876) [hereinafter Sauvinet Brief] (indicating Fellows wrote the brief).

388 Walker, 92 U.S. at 90 . Sauvinet's status as sheriff is not mentioned in the case report but appears in the brief filed on his behalf. See Sauvinet Brief, supra note 387, at 2. The dramatic possibilities of the encounter are delicious to contemplate, as reflected in numerous Hollywood variations on run-ins between African-American lawmen and racist rednecks, in films running the gamut of drama, see, e.g., In the Heat of the Night (1967), comedy, see, e.g., Blazing Saddles (1975), and action, see, e.g., Wild Wild West (1999).

389 See Walker, 92 U.S. at 90-92.

390 See id. at 92.

391 See id. at 92-93.

392 Id. at 92.

393 Id. 
That was it, as far as the Privileges and Immunities Clause was concerned. 394 Because the Seventh Amendment did not impose such a restriction on the states, "therefore," ipso facto, the Fourteenth Amendment did not do so either. The latter was indeed a "vain and idle enactment"! 395 Such "reasoning" rendered the Clause precisely nugatory, as Slaughter-House has been accused of doing, and with far more brutal efficiency. To call Waite's analysis unsatisfactory rather seriously understates the matter, in light of Senator Howard's 1866 speech $^{396}$ and Senator Norwood's 1874 articulation of the incorporationist reading of SlaughterHouse. ${ }^{397}$

But it gets worse. A study of the briefs filed with the Court reveals that Walker did not even raise before the Court the jury trial incorporation issue the Court decided. Walker apparently raised two federal constitutional objections in the state trial court: (1) that the substance of Louisiana's civil rights law violated his constitutional rights (in some vaguely unspecified way), and (2) that application of the procedural provisions of Louisiana's law abridged his right to jury trial in violation of the Fourteenth Amendment. ${ }^{398} \mathrm{He}$ apparently raised at least the latter claim before the Louisiana Supreme Court as well. ${ }^{399}$ But he

394 The Court's Due Process Clause analysis was only slightly more extensive. The Court stated that due process "does not necessarily imply that all trials... must be by jury. This requirement ... is met if the trial is had according to the settled course of judicial proceedings." Id. at 92-93 (citing Murray's Lessee v. Hoboken Land and Improvement Co., 59 U.S. (18 How.) 272, 280 (1856)). The Court's citation of Murray's Lessee was ironic, because that case contains language supporting the idea that "due process" encompasses all other procedural rights set forth in the Constitution, which would include the Seventh Amendment right to civil jury trial and all other specific procedural guarantees of the Bill of Rights. (Murray's Lessee involved the Fifth Amendment Clause, but its logic applies equally to that of the Fourteenth.) See Murray's Lessee, 59 U.S. (18 How.) at 276-77 ("To what principles . . . are we to resort to ascertain whether this process, enacted by congress, is due process?... We must examine the constitution itself, to see whether this process be in conflict with any of its provisions."); id. at 276 (specifically referring to Seventh Amendment as an example of such a provision); see also CURTIS, No STATE, supra note 22, at 166; Amar, supra note 22, at 1225-26; Crosskey, supra note 61 , at 6-7.

395 See Slaughter-House, 83 U.S. (16 Wall.) at 96 (Field, J., dissenting).

396 See supra Part I.B.

397 See supra Part III.A.1.

398 See Sauvinet Brief, supra note 387, at 2-3. Sauvinet's brief, unlike Walker's brief or the Court's reported opinion, provides a useful and detailed account of the case's procedural history in the lower courts. See id. at 2-4.

${ }^{399}$ See id. at 3-4. Sauvinet argued that Walker "abandoned [the jury trial point] in the State Court," $i d$. at 4, apparently referring to the Louisiana Supreme Court, though the basis of this argument is not clear, since Sauvinet's brief quoted Walker's request for rehearing in that court and the court's denial of rehearing, both of which addressed the jury issue. See id. at 3-4. 
abandoned the Fourteenth Amendment jury claim before the U.S. Supreme Court. No mention of it appears in his four-page brief filed in that Court. 400

The Fourteenth Amendment claim that Walker chose to press before the Court was that Louisiana's civil rights law, by requiring service of customers without regard to race, "compel[led] all persons engaged in business to sell their commodities whenever called upon to do so, and whether willing or not. Such compulsion is an abridgment of . . . the [citizen's] natural right to sell or keep his commodities as best suits his own purpose ...."401 This was, of course, exactly the kind of natural-law economic liberty argument that Justice Field had pressed unsuccessfully in Slaughter-House and that the Court later embraced as part of the ill-fated Lochner doctrine. ${ }^{402}$ Tellingly, though somewhat quixotically, the two decisions cited by Walker to support this argument were Slaughter-House

400 Walker's brief did argue that "the jury has a right ... to decide both law and fact, and no judge can lawfully compel the conscience of a jury on a constitutional question," Walker Brief, supra note 387 , at 4 , but this was part of Walker's third assignment of error, which expressly dealt only with claimed errors other than "the Federal questions involved," id. at 3. Walker's third assignment of error nowhere mentioned the Fourteenth Amendment, or any provision of federal law. See id at 3-4. Rather, that part of Walker's brief seemed to raise the issue whether the state trial judge had improperly charged the jury under state law, suggesting, contrary to basic principles limiting federal subject-matter jurisdiction, that "in examining a record from the highest court of a State," the U.S. Supreme Court might properly consider issues other than whatever federal questions were raised. See id. No record of the oral argument in Walker seems to have survived. Supreme Court oral arguments were not transcribed in any cases before 1936, and only in some cases between 1936 and 1965, according to a May 31, 2000, telephone conversation between Thomas Jefferson School of Law reference librarian Dorothy Hampton and Supreme Court briefs librarian Brian Stiglmeier. The few records of nineteenth-century arguments that do survive are either found in the summaries sometimes provided in the case reports, see, e.g., Spies v. Illinois, 123 U.S. 131, 143-59 (1887), or perhaps in the private papers of the attorneys involved, which may be the source of former Justice Campbell's Slaughter-House oral argument, quoted supra note 252. The very brief summary of Hornor's argument for Walker provided in the case report also fails to mention the jury trial issue, stating merely that the Louisiana law "under which the proceedings in this case were had, abridges the privileges and immunities of citizens of the United States, and is, therefore, in violation of the Fourteenth Amendment of the Constitution." Walker, 92 U.S. at 92 (summary of argument by C.W. Hornor) (citing Slaughter-House and Bartemeyer v. Iowa, 85 U.S. (18 Wall.) 129 (1874)). The citation of Slaughter-House and Bartemeyer, see supra note 284, both of which involved claimed economic liberties, reflects the Fourteenth Amendment argument actually pressed in Walker's brief, which had nothing to do with incorporation or jury trial, as discussed in text.

401 Walker Brief, supra note 387, at 2-3 (first assignment of error). Walker's second assignment of error was that Louisiana's law was null and void due to federal pre-emption, apparently on the theory that the Enforcement Clauses of the Reconstruction Amendments confided exclusive power in Congress to address such civil rights issues. See id. at 3 . Walker's third assignment of error did not raise any federal question. See supra note 400.

402 See supra Parts II.B-C. 
itself and Bartemeyer v. Iowa, ${ }^{403}$ an intervening case having nothing to do with incorporation, and which involved another unsuccessful economic liberty claim. 404

The Court in Walker refused to consider the economic liberty argument, or any questions other than the jury trial issue, on the sound enough ground that they were not properly raised and preserved in the courts below. ${ }^{405}$ Why the Court did not similarly apply the fundamental rule of judicial restraint that it should decline to address an issue not raised before the Court itself is a mystery. ${ }^{406}$ The Court not only wrongly decided the issue it chose to address, it did so without plausible analysis and in contravention of basic procedural propriety. One can only speculate why Walker chose (or rather, sought unsuccessfully) to abandon the jury trial issue before the Court, but a plausible explanation would be that his attorney took note of the decision in Edwards, which apparently postdated the lower-court proceedings in Walker. ${ }^{407}$

40385 U.S. (18 Wall.) 129 (1874).

404 See Walker Brief, supra note 387, at 3; supra note 284.

405 See Walker, 92 U.S. at 93 . Sauvinet took the same tack, not even bothering to respond on the merits to Walker's economic liberty argument. Sauvinet's attomey, J.Q.A. Fellows, did take some trouble to refute the Fourteenth Amendment jury trial claim Walker had raised in the lower courts (apparently accurately foreseeing that the Supreme Court might reach it notwithstanding Walker's abandonment of it there). See Sauvinet Brief, supra note 387, at 4-5. It is interesting to note that Fellows's duty to represent Sauvinet's interests led him to repudiate the incorporation theory that he and his then-co-counsel, former Justice Campbell, had supported in Slaughter-House. See supra Part II.D (quoting and discussing Slaughter-House Plaintiffs' Opening Brief (Campbell), supra note 246, and Slaughter-House Plaintiffs' Reargument Brief (Fellows), supra note 246). Fellows finessed the issue rather cleverly, merely noting: "In the Slaughter-House cases, the question of what constituted the privileges and immunities of citizens was discussed in extenso. But so far, no case has been found in which a trial by jury in a State court, was considered one of the rights, privileges or immunities of citizens of the United States." Sauvinet Brief, supra note 387, at 5 (citing Slaughter-House and four pre-1868 cases). This neatly avoided delving into what Slaughter-House had generally suggested the scope of such privileges and immunities should be (and what Fellows and Campbell had then argued it should be), while hiding behind the accurate technicality that no case had yet specifically incorporated any jury trial right.

406 See supra note 122.

407 Walker's brief did not cite Edwards. Nor, oddly enough, did Sauvinet's brief, even though the latter appears to have been filed about a year after Edwards was decided (precise dates of submission are not indicated on the briefs), and even though Sauvinet responded to Walker's abandoned jury trial argument and cited other cases in an attempt to refute application of civil jury trial to the states. See supra note 405; Walker Brief, supra note 387, at 1 (indicating filing during October 1874 term); Sauvinet Brief, supra note 387, at 1 (indicating filing during October 1875 term). The Court's docket was extremely backlogged during this time, which would account for the long delay between the filing of Walker's brief and the decision. See KACZOROWSKI, POLITICS, supra note 88, at 225 (docket "was two years in arrears" around this time). 
Justice Field dissented in Walker, though (uncharacteristically) without opinion. ${ }^{408}$ One might wish to think he was protesting the majority's unexplained repudiation of incorporation. While that would be consistent with his later embrace of that theory, ${ }^{409}$ however, it is far more likely that Field's dissent turned primarily on sympathy for Walker's claimed economic liberty of refusing service to those whose skin color he disliked. This conclusion is bolstered by Field's proven hostility to guaranteeing equal rights without regard to race. 410 Ironically enough, the other dissenter, also without opinion, was Justice Clifford, ${ }^{411}$ the author of Edwards, which further suggests that the incorporation debate had nothing to do with the dissents. Justice Clifford's likely hostility to Reconstruction and racial equality, and his consequent likely motivation for dissenting in Walker, may be inferred from facts noted earlier. ${ }^{412}$

Newsom argued that Edwards and Walker are consistent with the incorporationist thrust of Slaughter-House, primarily on the theory that the Seventh Amendment might not have been understood to guarantee any individual right susceptible to incorporation. ${ }^{413}$ Rather, Newsom argued, relying on Professor Amar, that the Amendment might have been understood merely as a structural or "federalist" provision, requiring jury trial in a common-law action heard in federal court only if a jury would have been provided by the state court

408 See Walker, 92 U.S. at 93 (noting that Field, J., dissented from opinion and judgment of Court).

${ }^{409}$ See O'Neil v. Vermont, 144 U.S. 323, 359-66 (1892) (Field, J., dissenting); Wildenthal, Road to Twining, supra note 4, at Part III.A.

410 See, e.g., Strauder v. West Virginia, 100 U.S. 303, 312 (1880) (Field, J., joined by Clifford, J., dissenting) (voting to uphold exclusion of African-Americans from state juries); $E x$ parte Virginia, 100 U.S. 339, 367-70 (1880) (Field, J., joined by Clifford, J., dissenting) (same).

411 See Walker, 92 U.S. at 93. The U.S. Reports states simply that "Mr. Justice Field and Mr. Justice Clifford dissented from the opinion and judgment of the court." Id. The Lawyers' Edition reports an actual brief dissent by Clifford, stating: "I dissent from the opinion and judgment of the court in this case, and I am requested to say that Mr. Justice Field also dissents both from the opinion and judgment." $23 \mathrm{~L}$. Ed. at 679.

412 See supra note 383 and accompanying text. Indeed, Justice Clifford joined Justice Field as the only two dissenters in Strauder and its companion case, which struck down racial exclusion from jury service. See supra note 410.

413 See Newsom, supra note 22, at 727-32. Newsom also unearthed intriguing evidence that Justice Miller in particular harbored a strong personal hostility to civil jury trial. See id. at 730-31. But while that might explain (without justifying) Miller's silent concurrences in Edwards and Walker, it does not explain the more puzzling concurrences of Justices Bradley and Swayne, or indeed those of the other Justices who joined Miller's Slaughter-House opinion (all of whom concurred in Edwards, and all but Clifford in Walker). See infra Part IV. 
that would otherwise have heard the action. ${ }^{414}$ Amar argued that the Amendment was so understood at the time of its adoption in 1791.415

Professor Stanton Krauss also recently argued that the Amendment was not originally understood to guarantee any individual right, though he rejected Amar's theory as well, concluding instead that the Amendment was designed to allow Congress plenary authority to define when civil jury trial would be available in federal court. ${ }^{416}$ Amar and Krauss both also conceded that the modern Supreme Court has, by contrast, long read the Amendment to guarantee the right to civil jury trial in federal court to the extent that it "existed under the English common law when the Amendment was adopted." 17 There seems no compelling reason why the Amendment, as so conceived by the Court, would not be subject to incorporation against the states. 418

Resolving the original understanding of the Seventh Amendment is beyond the ambition of this article. But while Professor Amar noted that incorporation of the Seventh Amendment into the Fourteenth "becomes somewhat awkward"419 under his view of the original understanding of the former, his more fundamental insight was that in resolving any incorporation issue, we should look at how the provision in question was understood by the Civil War generation. ${ }^{420}$ Neither Amar nor Newsom exhaustively explored (and Krauss not at all) how the Seventh Amendment was understood during that Era. Yet only by doing so can we assess whether Edwards and Walker were "sui generis" statements about the Seventh Amendment alone, ${ }^{421}$ or posed a more generalized contradiction to the incorporationist implications of Slaughter-House. A definitive study of how the Seventh Amendment was understood during the Civil War Era is also beyond the

414 See Newsom, supra note 22, at 729 \& nn.418-421 (citing AMAR, BIL OF RIGHTS, supra note 63 , at $89,92,276$ ).

415 See AMAR, BLL OF RIGHTS, supra note 63, at 89-93.

416 See Stanton D. Krauss, The Original Understanding of the Seventh Amendment Right to Jury Trial, 33 U. RICH. L. REV. 407, 408-09, 445-59, 479-83 (1999).

417 Markman v. Westview Instruments, Inc., 517 U.S. 370, 376 (1996) (quoting Baltimore \& Carolina Line, Inc. v. Redman, 295 U.S. 654 (1935)) (internal quotation marks omitted); see also AMAR, BIL OF RIGHTS, supra note 63, at 89; Krauss, supra note 416, at 409.

418 Cf. AMAR, BLL OF RIGHTS, supra note 63, at 276 (offering what Amar conceded was "some fancy doctrinal footwork" in an attempt to "explain why the [structural] reading of the Seventh Amendment makes sense in the incorporation context even though the Supreme Court does not embrace it in Seventh Amendment doctrine proper"); infra note 573 (noting that stare decisis would today counsel against overnuling Edwards and Walker, even if the Seventh Amendment was properly incorporated as a theoretical matter).

419 AMAR, BILL OF RIGHTS, supra note 63, at 92.

${ }^{420}$ See id. at xii-xv, 284-94. As Amar stated, "words inserted into the Constitution in 1791 must be read afresh after 1866." Id. at 283.

421 See Newsom, supra note 22, at 732. 
scope of this article. A preliminary survey, however, severely undercuts Newsom's view.

Newsom did not consider how the Supreme Court itself dealt with the Seventh Amendment in the years leading up to Edwards and Walker. The modern Court's view is that the individual-right conception of the Amendment has prevailed "[s]ince Justice Story's day,"422 decades before the Civil War. And indeed, in the 1833 case of Livingston v. Moore, ${ }^{423}$ immediately after Barron itself, the Court rejected a claim that Pennsylvania had violated the right to civil jury trial, not on the basis of any structural theory of the Amendment like those suggested by Amar, Krauss, or Newsom, but simply because it "[did] not extend to the states." 424 In 1856, the Court analogized the Seventh Amendment jury trial right to that of the Sixth Amendment, describing them collectively as "further special provisions ... for that mode of trial in civil and criminal cases," 425 and holding that all such constitutional guarantees are encompassed by the concept of due process of law. 426

In 1870, the Court construed the Reexamination Clause of the Seventh Amendment ${ }^{427}$ to prohibit retrial, upon removal of a case to federal court, of facts tried in state court. ${ }^{428}$ The Fourteenth Amendment was not raised, and the Court stated, on the basis of Barron, Livingston, and Twitchell, that the Seventh Amendment itself "could not be invoked in a State court to prohibit it from re-

422 Markman, 517 U.S. at 376; accord Curtis v. Loether, 415 U.S. 189, 193 (1974). But see Krauss, supra note 416, at 460-78 (disputing this conventional account).

42332 U.S. (7 Pet.) 469 (1833).

424 Id. at 552 .

425 Murray's Lessee v. Hoboken Land and Improvement Co., 59 U.S. (18 How.) 272, 276 (1856).

426
427 Tee id. at $276-77 ;$ supra note 394.

In suits at common law, where the value in controversy shall exceed twenty dollars, the right of trial by jury shall be preserved [the Jury Trial Clause], and no fact tried by a jury, shall be otherwise re-examined in any court of the United States, than according to the rules of the common law [the Reexamination Clause].

U.S. CONST. amend. VII. This article, consistent with traditional practice in cases and scholarship dealing with the incorporation issue, treats both Clauses as components of one unified right to civil jury trial. But this approach may well be too simplistic, because the Court has long treated the Clauses separately for purposes of Seventh Amendment analysis. See, e.g., Gasperini v. Ctr. for Humanities, Inc., 518 U.S. 415, 432 (1996) (construing Reexamination Clause); Markman, 517 U.S. at 376 (construing Jury Trial Clause); see also Justices of the Sup. Ct. of N.Y. v. Murray, 76 U.S. (9 Wall.) 274, 277 (1870); Parsons v. Bedford, 28 U.S. (3 Pet.) 433,447 (1830).

${ }^{428}$ Murray, 76 U.S. ( 9 Wall.) at 277-82. 
examining ... facts that had been tried by a jury."429 But the Court found the incorporation issue irrelevant because "the question in hand... is not whether ... the [Seventh] [A]mendment has any effect as to the powers of an appellate State court, but what is its effect upon the powers of the Federal appellate court?"430 The clear implication was that if Barron were overuled, as it effectively was by the Fourteenth Amendment under the incorporation theory, then the Seventh Amendment would apply to state courts.

Newsom also placed unwarranted stress on the fact that civil jury trial was occasionally omitted from the typically nonexhaustive catalogues of Bill of Rights guarantees thought to apply to the states, as offered by some contemporary figures favoring incorporation. 431 Newsom conceded one example contrary to his thesis, ${ }^{432}$ and there are others that he did not mention. For example, Representative Beck cited the Seventh Amendment as applying to the states in 1873.433 Representative Bingham himself, the father of incorporation, endorsed that view in both 1866 and again in 1871, citing (along with Barron itself) the Court's refusal in Livingston to enforce the Seventh Amendment against the states as one of the antebellum decisions that were "exactly what makes plain the necessity of adopting th[e] [Fourteenth] [A]mendment."434

429 Id. at 278; see also supra note 124.

430 Id.; see also supra note 124.

431 See, e.g., Newsom, supra note 22, at 729 (arguing that Sen. Howard "conspicuously omitted any reference to the right to a civil jury" in his 1866 speech). But Sen. Howard referred to "the personal rights guarantied [sic] and secured by the first eight amendments ... such as the freedom of speech [etc.]" CONG. GlOBE, 39th Cong., 1st Sess. 2765 (May 23, 1866) (emphasis added). While he listed rights found in the First, Second, Third, Fourth, Sixth, and Eighth Amendments, he omitted (along with the Seventh) the Religion Clauses of the First, all four rights guaranteed by the Fifth, five of the seven guaranteed by the Sixth, and one of the three guaranteed by the Eighth. See id.; supra note 90 (cataloguing twenty-four privileges and immunities in Bill of Rights). Newsom's argument thus proves altogether too much. Cf. supra note 312 (discussing Sen. Norwood's arguable omission of civil jury trial from his list of incorporated rights, an example not noted by Newsom).

432 See Newsom, supra note 22, at 730 n.424 (citing CONG. GLOBE, 41st Cong., 3d Sess. 1245 (1871) (Rep. Lawrence)); see also supra Part III.A.1 (discussing Lawrence's 1874 incorporationist speech).

4332 CONG. REC. 343 (Dec. 19, 1873); supra Part III.A.1. Rep. Herndon referred generally to "trial by jury" without specifying criminal or civil, in listing "a few" of the privileges protected by the Fourteenth Amendment. See 2 CONG. REC. 420 (Jan. 6, 1874); supra Part III.A.1.

434 CONG. GLOBE, 39th Cong., 1st Sess. 1089-90 (Feb. 28, 1866). In 1871, recalling his incorporationist design in proposing the Amendment, Bingham repeated the linked reference to Barron and Livingston and recited the Seventh Amendment along with the First through Eighth Amendments as applying to the states via the Fourteenth Amendment. See CONG. GLOBE, 42d Cong., 1st Sess. app. 84 (Mar. 31, 1871). 
Additional evidence is furnished by Justice Story's Commentaries, originally published in 1833 and reissued in 1873 under the editorship of Chief Justice Cooley. 435 This treatise declared that the Seventh Amendment

secured the right of a trial by jury in civil cases in the fullest latitude of the common law .... [T]t is a most important and valuable amendment, and places upon the high ground of constitutional right the inestimable privilege of a trial by jury in civil cases, - a privilege scarcely inferior to that in criminal cases, which is conceded by all to be essential to political and civil liberty. 436

Newsom argued that "at least a handful of states voting to ratify the Fourteenth Amendment had procedures in place that would not have complied with an incorporated Seventh Amendment."437 But of the thirty-seven states in the Union in 1868, all but one-Louisiana with its Napoleonic civil law heritage ${ }^{438}$ _ guaranteed that procedure as a matter of state constitutional right, in a manner at least substantially in accord with the Seventh Amendment. 439

435 See 1 COOLEY ON STORY 1873, supra note 360, at v-ix (prefaces); supra Part III.A.3. 4362 COOLEY ON STORY 1873, supra note 360 , at 526 . Another Cooley treatise stated:

The several State constitutions preserve the right of trial by jury, with permission in some for the parties to waive the right in civil cases. Those cases which before the constitution were not triable by jury need not be made so now.... But the legislature cannot deprive a party of a common-law right... and compel him to abide the estimate of commissioners upon his damages. Where the constitution gives the right, it cannot be made by statute to depend upon any condition.

COOLEY, CONSTITUTIONAL LIMTTATIONS 1874 , supra note 363 , at $* 410 \mathrm{n} .1$ (citations omitted).

437 Newsom, supra note 22, at 730 \& n.424 (citing Fairman, supra, note 22, at 81-132).

438 Even Louisiana, though not expressly guaranteeing civil jury trial in its constitution, appeared to provide it in major cases. The Louisiana Constitution of 1868 vested original jurisdiction over certain cases in which less than five hundred dollars was in dispute in its parish courts, and stated: "There shall be no trial by jury before the parish courts." See LA. CONST. of 1868, tit. IV, art. 87, reprinted in 4A SOURCES AND DOCUMENTS OF UNITED STATES CONSTITUTIONS 154 (William F. Swindler ed. 1973-79) [hereinafter ST. CoNST.]. The constitution vested district courts with original jurisdiction over cases involving more than five hundred dollars, implying by silent contrast that jury trial was available in those courts. See id. art. 85, reprinted in 4A ST. CONST., supra at 154.

439 See ALA. CONST. of 1867 , art. I, $\S 13$, reprinted in 1 ST. CONST., supra note 438 , at 83; ARK. CONST. of 1868, art. I, $\S 6$, reprinted in 1 ST. CONST., supra note 438, at 382; CAI. CONST. of 1849, art. I, $\S 3$, reprinted in 1 ST. CONST., supra note 438, at 447; CONN. CONST. of 1818 , art. I, $\S 21$, reprinted in 2 ST. CONST., supra note 438, at 145; DEL. CONST. of 1831, art. I, $\S 4$, reprinted in 2 ST. CONST., supra note 438, at 217; FLA. CONST. of 1868, art. I, §4, reprinted in 2 ST. CONST., supra note 438 , at 353; GA. CONST. of 1868 , art. V, $\S 13$, reprinted in 2 ST. CONST., supra note 438, at 508; ILL. CONST. of 1848, art. XIII, $\S 6$, reprinted in 3 ST. CONST., supra note 438 , at 267; IND. CONST. of 1851, art. I, $\S 20$, reprinted in 3 ST. CONST., supra note 438, at 379; IOWA CONST. of 1857, art. I, § 9, reprinted in 3 ST. CONST., supra note 
For all these reasons, it seems impossible to explain away Edwards and Walker as Newsom would do, on the theory that the Seventh Amendment was understood to be uniquely unsusceptible to incorporation. Walker in particular stands as a puzzling contradiction to any notion that the apparent incorporationist consensus of Slaughter-House had any staying power.

\section{The Confusion in the Supreme Court, Part 2: Cruikshank}

On March 27, 1876, one month before Walker was decided, the Court rendered its decision in United States v. Cruikshank, 440 in another opinion by Chief Justice Waite. Waite wrote for a majority of eight, with Justice Clifford filing a separate opinion concurring only in the judgment. ${ }^{441}$ The story of

438, at 452; KAN. CONST. of 1859, Bill of Rights, $§ 5$, reprinted in 4 ST. CONST., supra note 438 , at 83 ; KY. CONST. of 1850 , art. XIII, $\S 8$, reprinted in 4 ST. CONST., supra note 438 , at 182; ME. CONST. of 1819, art. I, $\S 20$, reprinted in 4 ST. CONST., supra note 438, at 316; MD. CONST. of 1867, Decl. of Rights, art. 5, reprinted in 4 ST. CONST., supra note 438, at 448; MASS. CONST. of 1780, Decl. of Rights, art. XV, reprinted in 5 ST. CONST., supra note 438, at 95; MiCH. CONST. of 1850, art. VI, $\S 27$, reprinted in 5 ST. CONST., supra note 438, at 230; MINN. CONST. of 1857, art. I, $\S 4$, reprinted in 5 ST. CONST., supra note 438, at 303; MiSS. CONST. of 1868 , art. I, $\$ 12$, reprinted in 5 ST. CONST., supra note 438 , at 377; MO. CONST. of 1865 , art. I, $\S 17$, reprinted in 5 ST. CONST., supra note 438, at 517; NEB. CONST. of 1867, art. I, $\S 5$, reprinted in 6 ST. CONST., supra note 438, at 151; NEv. CONST. of 1864, art. I, § 3, reprinted in 6 ST. CONST., supra note 438, at 263-64; N.H. CONST. of 1784, Bill of Rights, art. $\mathrm{XX}$, reprinted in 6 ST. CONST., supra note 438, at 346; N.J. CONST. of 1844, art. I, $\S 7$, reprinted in $6 \mathrm{ST}$. CONST., supra note 438, at 454; N.Y. CoNST. of 1846, art. I, § 2, reprinted in 7 ST. CONST., supra note 438, at 192; N.C. CONST. of 1868, art. I, $\S 19$, reprinted in 7 ST. CONST., supra note 438, at 415; OHIO CONST. of 1851, art. I, $\S 5$, reprinted in 7 ST. CONST., supra note 438, at 558; OR. CONST. of 1857 , art. I, $\$ 18$, reprinted in 8 ST. CONST., supra note 438, at 206; PA. CONST. of 1838, art. IX, $\S 6$, reprinted in 8 ST. CONST., supra note 438, at 303; R.I. CONST. of 1842, art. I, $\S 15$, reprinted in 8 ST. CONST., supra note 438, at 388; S.C. CoNST. of 1868 , art. I, $\S 11$, reprinted in 8 ST. CONST., supra note 438, at 494; TENN. CONST. of 1834, art. I, $\S 6$, reprinted in 9 ST. CONST., supra note 438 , at 153; TEX. CONST. of 1868 , art. V, $\S 16$, reprinted in 9 ST. CONST., supra note 438, at 308; VT. CONST. of 1796, Decl. of Rights, art. XII, reprinted in 9 ST. CONST., supra note 438, at 508; VA. CONST. of 1851, Bill of Rights, art. XI, reprinted in 10 ST. CONST., supra note 438, at 69; W. VA. CONST. of 1863, art. II, $\S 7$, reprinted in 10 ST. CONST., supra note 438 , at 343 ; WIS. CoNST. of 1848 , art. I, $\S 5$, reprinted in 10 ST. CONST., supra note 438 , at 418.

44092 U.S. 542 (1876); see also id., 23 L. Ed. at 589 (giving exact date of decision). The fact that the case report of Cruikshank is published almost five hundred pages after Walker in Volume 92 of the U.S. Reports has understandably confused some scholars, including Professor Morrison, into thinking that Cruikshank postdated Walker. See, e.g., Morrison, supra note 6, at 145. They are published in the correct order in the Lawyer's Edition. See Cruikshank, 23 L. Ed. at 588; Walker v. Sauvinet, 23 L. Ed. 678 (1876).

441 See Cruikshank, 92 U.S. at 559 (Clifford, J., separate opinion). The case report labels Clifford's opinion as "dissenting" (presumably at his request, and apparently because he 
Cruikshank, yet another case arising from turbulent Reconstruction-Era Louisiana, has been oft-told. The decision has often been criticized for unduly narrowing Congress's enforcement powers under the Fourteenth Amendment and for presaging the strict view of state action that the Court later adopted in the Civil Rights Cases.442 The conventional wisdom has viewed the Court's opinion as rejecting the incorporation theory, 443 and furthermore, as merely confirming what Slaughter-House had already accomplished. ${ }^{444}$

Professor Palmer, the first scholar to explore in depth the incorporationist reading of Slaughter-House, ${ }^{445}$ argued by contrast that Cruikshank "accomplished the nullification of the fourteenth amendment that scholars traditionally attribute to Slaughter-House."446 Newsom, carrying Palmer's revisionism a step further, argued that even Cruikshank did not reject incorporation. 447 This all requires careful consideration. It may be noted at the outset, however, that if Palmer was right, then even he understated the full irony and illegitimacy of Cruikshank's trashing of incorporation. Neither Palmer nor Newsom addressed the facts, as discussed below, that the government abandoned before the Supreme Court the only aspects of the case implicating the incorporation issue and that one of the defendants' attorneys conceded an incorporationist reading of the Fourteenth Amendment.

The facts of Cruikshank "involved a level of violence tantamount to a localized civil war in what was perhaps the bloodiest racial conflict in Louisiana history." $" 48$

The case arose out of the outrages of the Colfax massacre, the "bloodiest single instance of racial camage in the Reconstruction era." After the disputed gubernatorial election of 1872 in Louisiana, blacks in the town of Colfax organized themselves for

disagreed with Waite's reasoning), but the first sentence of his opinion states: "I concur that the judgment in this case should be arrested, but for reasons quite different from those given by the court." Id.

442109 U.S. 3 (1883); see also United States v. Harris, 106 U.S. 629 (1883). For criticisms directed mainly to the state action aspects of Cruikshank, see, e.g., KACZOROWSKI, POLITICS, supra note 88, at 173-229, and Curtis, Resurrecting, supra note 41, at 86-90. For criticisms directed mainly to the incorporation aspects of Cruikshank, see, e.g., CURTIS, No STATE, supra note 22, at 178-79, Aynes, Bingham, supra note 54, at 99-103, and Palmer, supra note 22, at 762-69.

443 See, e.g., CURTIS, No STATE, supra note 22, at 178-79; Aynes, Bingham, supra note 54, at 99-103; Curtis, Resurrecting, supra note 41, at 86-90; Palmer, supra note 22, at 762-69.

444 See, e.g., CURTIS, No STATE, supra note 22, at 178 ("By the time Cruikshank was decided the Court considered the meaning of the Fourteenth Amendment settled.").

445 See Palmer, supra note 22, at 741-62.

446 Id. at 762 .

447 See Newsom, supra note 22, at 712-20.

448 KACZOROWSKI, POLITICS, supra note 88, at 175. 
self-defense against an expected attempt by white Democrats to seize control over the government. On Easter Sunday, 1873, a mob of white citizens armed with rifles and a small cannon overwhelmed the defenders and engaged in a day of indiscriminate killing. Two whites and 280 blacks were killed-including fifty black men who had laid down their arms under a flag of surrender. ${ }^{449}$

By eerie coincidence, the massacre took place the day before SlaughterHouse was decided. ${ }^{450} \mathrm{~A}$ federal grand jury indicted ninety-seven of the alleged killers in June $1873^{451}$ under the Enforcement Act of 1870.452 Nine were brought to trial in February 1874 before U.S. Circuit Judge (later Justice) William B. Woods, resulting in one acquittal and a hung jury on the others. ${ }^{453}$ Retrial of the remaining eight defendants began in May 1874, with Justice Bradley himself joining Judge Woods in presiding. This time five defendants were acquitted, but three, including William Cruikshank, were found guilty of sixteen counts of conspiracy to violate various federal constitutional rights. ${ }^{454}$

Justice Bradley, however, in a circuit court opinion issued on June 27, 1874, quashed the indictment. ${ }^{455} \mathrm{He}$ relied on a straightforward state-action theory to limit the scope of the Fourteenth Amendment. The criminal prosecutions at issue exceeded federal power, he held, because they reached private assaults on life and liberty, whereas the Amendment was "a guaranty of protection against the acts of the state government itself." 456 Most scholars, concerned primarily with the state action issue, have emphasized that Bradley's 1874 decision foreshadowed in that

449 McConnell, Moment, supra note 56, at 134-35 (quoting FoNER, supra note 88, at 437).

450 IRONS, supra note 250, at 202.

451 KACZOROWSKI, POLITICS, supra note 88, at 176.

452 Ch. CXIV, 16 Stat. 140.

453 See KACZOROWSKI, POLIICS, supra note 88, at 176-78; see also supra Part II.A (noting Judge Woods's endorsement of incorporation in 1871). Federal authorities were overwhelmed by the task of tracking down the hundreds of armed bandits involved. Despite the pleas of local U.S. Attorney James R. Beckwith for more vigorous enforcement support, Attomey General George $\mathrm{H}$. Williams ordered Beckwith to select only a handful of ringleaders for actual prosecution. According to Professor Kazcorowski, this decision by the Grant Administration "represented cynical tokenism." KACZOROWSKI, POLITICS, supra note 88, at 176.

454 Id. at 178.

455 United States v. Cruikshank, 25 F. Cas. 707 (C.C.D. La. 1874) (Bradley, Circuit Justice), aff'd, 92 U.S. 542 (1876); see also KACZOROWSKI, POLITICS, supra note 88, at 179.

456 Cruikshank, 25 F. Cas. at 710. The Amendment, he held, was "not intended as a guaranty against the commission of murder, false imprisonment, robbery, or any other crime committed by individual malefactors, so as to give congress the power to pass laws for the punishment of such crimes in the several states generally." Id.; see also id. at 714-15 (discussing Fourteenth Amendment rights that the indictment alleged the defendants violated). 
regard the full Court's holdings on appeal in Cruikshank, in United States $v$. Reese, ${ }^{457}$ and ultimately in the Civil Rights Cases of 1883.458

What seems to have gone unnoticed until very recently, however, is that Justice Bradley's 1874 opinion most emphatically did not foreshadow any abandonment of incorporation. Quite the contrary: Justice Bradley explicitly reaffirmed the incorporationist consensus implied by Slaughter-House and echoing in the halls of Congress that very winter and spring of 1874.459 Noting that the first count of the Cruikshank indictment dealt with the right of peaceable assembly, Bradley observed that this right was guaranteed by the First Amendment, which did not address private actions but only limited Congress's own power. ${ }^{460} \mathrm{He}$ found this count void, but only under his state action theory:

Has anything since [the First Amendment] occurred to give congress legislative power over the subject matter? The 14th amendment declares that no state shall by law abridge the privileges or immunities of citizens of the United States. Grant that this prohibition now prevents the states from interfering with the right to assemble, as being one of such privileges and immunities, still, does it give congress power to legislate over the subject? Power to enforce the amendment is all that is given to congress. If the amendment is not violated, it has no power over the subject. ${ }^{461}$

45792 U.S. 214 (1876). Reese, decided the same day as Cruikshank, involved Congress's power to enforce the Fifteenth Amendment (which was also at issue in Cruikshank). See KACZOROWSKI, POLITICS, supra note 88, at 213.

458109 U.S. 3 (1883). Professor John Braeman, for example, noted that Bradley, following his broad interpretation of the Fourteenth Amendment in Slaughter-House, see supra note 112 (discussing Bradley's 1870 circuit court opinion in Slaughter-House); supra Part II.D (discussing Bradley's Supreme Court dissent in Slaughter-House), began "shift[ing] his ground" in his 1874 Cruikshank decision. See BRAEMAN, supra note 88, at 64; see also id. at 64-67 (discussing Cruikshank, Reese, and Civil Rights Cases); John Anthony Scott, Justice Bradley's Evolving Concept of the Fourteenth Amendment From the Slaughter-House Cases to the Civil Rights Cases, 25 RUTGERS L. REV. 552 (1971) (discussing the role of Bradley's dissent in the Slaughter-House Cases in conceptualizing the scope of the Fourteenth Amendment). Professor Kaczorowski blamed Justice Bradley's decisions in Cruikshank and in Texas v. Gaines, 23 F. Cas. 869 (C.C.W.D. Tex. 1874), for a new explosion of political and racial violence across the South. KACZOROWSKI, POLITICS, supra note 88, at 188.

459 See supra Part III.A.1.

460 See Cruikshank, 25 F. Cas. at 714-15.

461 Id. at 714-15 (emphasis added). Referring to the second count, which dealt with the right to bear arms, Bradley merely noted that it was "open to the same criticism as the first." Id. at 715; see also HALBROOK, supra note 52, at 168 (noting the incorporationist aspect of Bradley's 1874 opinion); BRANDWEN, supra note 41, at 71, 80 (same); Newsom, supra note 22 , at 717,720 (same). 
Since Bradley's views on the Fourteenth Amendment were, by this time, necessarily guided by the majority's holding in Slaughter-House, ${ }^{462}$ this passage constitutes still more compelling evidence that incorporation was, by this time, widely accepted as a minimum consensus view of the Amendment.

Nevertheless, Chief Justice Waite's opinion two years later affirming Justice Bradley's quashing of the indictment ${ }^{463}$-joined silently by Bradley himself seemed to offhandly reject incorporation. Waite found all sixteen counts of the indictment legally invalid. Oddly, he cited Slaughter-House only once, toward the beginning of his opinion, for the general proposition that the rights of a citizen of the United States differ from those of a citizen of a state. ${ }^{464}$ After elaborating awhile on the theme of dual citizenship, Waite turned to the first, second, ninth, and tenth counts of the indictment, which essentially alleged that the defendants had violated the victims' First Amendment right of peaceable assembly and their Second Amendment right to bear arms. ${ }^{465}$ Instead of simply relying on the obvious state-action weakness of those counts, as Bradley had done, Waite recited the rule that those amendments applied of their own force only to the federal government, citing Barron and pre- 1868 cases. ${ }^{466}$ The only post- 1868 cases cited were Twitchell and Edwards. ${ }^{467}$

Chief Justice Waite did not even mention the Fourteenth Amendment or Slaughter-House in his discussion of the counts dealing with peaceable assembly and the right to bear arms. The closest he came even to an implicit reference to the Amendment, or to anything remotely resembling analysis of the incorporation issue, was to state:

The right of the people peaceably to assemble for the purpose of petitioning Congress for a redress of grievances, or for any thing else connected with the powers or the duties of the national government, is an attribute of national citizenship, and, as such, under the protection of, and guaranteed by, the United States. The very idea of a government, republican in form, implies a right on the part of its citizens to meet peaceably for consultation in respect to public affairs and to petition for a redress of grievances. If it had been alleged in these counts that the object of the defendants was to prevent a meeting for such a purpose, the case would have been within the statute,

462 See, e.g., KACZOROWSKI, POLITCS, supra note 88, at 179-83; see also Cruikshank, 25 F. Cas. at 712 (citing Slaughter-House, 83 U.S. (16 Wall.) at 81 ).

463 Justice Bradley certified the case to the Supreme Court because he and Judge Woods were divided on the issue, with Woods favoring upholding the validity of the indictment. See Cruikshank, 92 U.S. at 546, 548; Cruikshank, 25 F. Cas. at 708; KACZOROWSKI, POLITICs, supra note 88 , at $177-78$.

464 See Cruikshank, 92 U.S. at 549.

465 Id. at 551-53.

466 Id, see also supra Part II.A (discussing Barron).

467 Cruikshank, 92 U.S. at 552; see also supra Part II.A (discussing Twitchell); supra Part III.B (discussing Edwards). 
and within the scope of the sovereignty of the United States. Such, however, is not the case. The offence, as stated in the indictment, will be made out, if it be shown that the object of the conspiracy was to prevent a meeting for any lawful purpose whatever. 468

Here would seem to be the origin of the narrow conventional reading of Slaughter-House to recognize only those privileges and immunities deriving from some relationship with the federal government.

With regard to the right to bear arms, Chief Justice Waite stated simply: "The second amendment declares that [this right] shall not be infringed; but this, as has been seen, means no more than that it shall not be infringed by Congress." 469 One might argue that the Second Amendment, unlike other Bill of Rights guarantees, is inherently unsusceptible to incorporation because it is not so much an individual right against governmental power generally, but a right of the states against the federal government to maintain a "well regulated Militia." 470 Modern scholarship has cast doubt on whether the Second Amendment may be construed in so limited a manner, but that issue is beyond the scope of this article. 471

The remainder of Chief Justice Waite's Cruikshank opinion emphasized three general weaknesses of the various counts of the indictment that rendered his incorporation-related discussion utterly needless. First, echoing Justice Bradley's circuit court opinion, Waite pointed to the lack of alleged state action arguably requisite under the Fourteenth and Fifteenth Amendments. ${ }^{472}$ Second, he pointed to the arguable lack of sufficient allegations of racial motivation. ${ }^{473}$ Third, he pointed to the indictment's overall vagueness, generality, and arguable lack of fair notice. 474

The federal government's brief in Cruikshank referred to "the right to assemble and consult about Federal politics, and to petition Congress for redress

468 Cruikshank, 92 U.S. at 552-53.

469 Id. at 553.

470 U.S. CONST. amend. II.

471 See generally HALBROOK, supra note 52 (arguing that historical evidence from 186676 supports incorporation of individual right to bear arms in Fourteenth Amendment); Koren Wai Wong-Ervin, Note, The Second Amendment and the Incorporation Conundrum: Towards a Workable Jurisprudence, 50 HASTINGS L.J. 177 (1998) (surveying scholarship and also contending that right is properly incorporated); see also AMAR, BLL OF RIGHTS, supra note 63, at 46-63,257-66 (lending considerable support to individual-right, incorporationist view of Second Amendment).

472 Cruikshank, 92 U.S. at 553-56.

$473 \mathrm{Id}$. at $554-56$.

${ }^{474}$ Id. at $557-59$. 
of Federal grievances,"475 but the government expressly emphasized that these were rights that did not originate with the Fourteenth Amendment but rather had existed, along with the federal power to enforce and protect them, "at any time since 1789." 476 The government argued that even if it were shown that some rights addressed in the indictment did not fall within federal protection, "we reply that such conclusion is not material."477 As long as there were "some such we are not interested in this connection to say whether they be more or less, or to settle the debate whether certain rights are upon this or that side of the boundary." 478 In other words, the government seems not to have wanted to address the incorporation debate.

Indeed, the Court had no need to address the counts dealing with peaceable assembly and bearing of arms at all because the government had abandoned them, along with all counts other than the sixth, eighth, fourteenth, and sixteenth. ${ }^{479}$ The latter counts alleged denial of the right to vote and, generally, of "ceach, every, all and singular [of] the several rights and privileges granted or secured ... by the Constitution and laws of the United States." 480 Chief Justice Waite disposed of them without reference to the incorporation issue, on the basis of the three weaknesses mentioned above. ${ }^{481}$ Thus, the briefs reveal that to whatever extent incorporation was rejected or undermined in Cruikshank, this was not only unnecessary and unreasoned, it was also (like the similar holding in Walker) procedurally improper.

The government, as noted, seemed to deliberately avoid the incorporation issue, despite its natural stake in promoting the theory. Paradoxically, one of the briefs filed on behalf of the defendants, who had every incentive to oppose incorporation, actually endorsed the theory. Four briefs were filed on behalf of the defendants, the dominant theme of all four being the lack of state action. ${ }^{482}$

475 Brief for the United States at 6, United States v. Cruikshank, 92 U.S. 542 (1876) [hereinafter Cruikshank U.S. Brief] (citing Slaughter-House, 83 U.S. (16 Wall.) at 79). The Supreme Court briefs in Cruikshank are reprinted in 7 LANDMARK BRIEFS, supra note 246, at 285-417.

476 Cruikshank U.S. Brief, supra note 475 , at 6.

$477 \mathrm{Id}$. at 26.

478 Id. at $26-27$.

479 See id. at 3.

480 Id. at 4 ; see also id. at 3-4, 26.

481 See Cruikshank, 92 U.S. at 555-59.

482 See Brief for Defendants (filed by David S. Bryon) at 18-26, United States v. Cruikshank, 92 U.S. 542 (1876) [hereinafter Cruikshank Defendants' Brief (Bryon)]; Brief for Defendants (filed by R.H. Marr) at 7-24, United States v. Cruikshank, 92 U.S. 542 (1876) [hereinafter Cruikshank Defendants' Brief (Marr)]; Brief for Defendants (filed by John A. Campbell) at 4-11, 24-28, United States v. Cruikshank, 92 U.S. 542 (1876) [hereinafter 
Only two of the defendants' briefs clearly addressed incorporation, and they did so in cursory fashion. One seemed to argue against incorporation, though in notably unpersuasive fashion. ${ }^{483}$ The other, however, conceded that the Fourteenth Amendment incorporates the Bill of Rights. ${ }^{484}$ Cruikshank, like Walker, involved yet another of the Slaughter-House attorneys, in this case former Justice Campbell. Campbell's brief took no clear position on incorporation, perhaps not surprisingly, given the conflict between his clients' interests and his own espousal of the theory in Slaughter-House. ${ }^{485}$

Cruikshank Defendants' Brief (Campbell)]; Brief for Defendants (filed by David Dudley Field) at 4-5, United States v. Cruikshank, 92 U.S. 542 (1876).

483 See Cruikshank Defendants' Brief (Bryon), supra note 482, at 10, 14. Bryon simply misquoted Slaughter-House, stating that it was "decided in [Slaughter-House] that it is one of the rights of citizens of the United States, resulting not from any particular article of the Constitution, but from the general nature of the government, to peaceably assemble, provided it be 'to petition the government for a redress of grievances."' Id. at 10. In fact, as discussed in Part II.C, it was exactly the reverse. The sentence in Justice Miller's majority opinion in Slaughter-House referring to the right of assembly expressly noted that it was rooted in "the Federal Constitution," in contrast to other rights listed by Miller which he linked to the "National character" of the federal government. See Slaughter-House, 83 U.S. (16 Wall.) at 79. And Miller, contrary to Bryon's quotation above, dropped from Slaughter-House's paraphrase of the right of petition any mention of "the government" (presumably meaning the federal govemment) as the exclusive target. See id.; supra Part II.C. Bryon later asserted, with no explanation at all, that 'the right to bear arms is not enumerated [he meant, presumably, in Slaughter-House's avowedly nonexhaustive list] among the rights of a citizen of the United States." Cruikshank Defendants' Brief (Bryon), supra note 482, at 14.

${ }^{484}$ See Cruikshank Defendants' Brief (Marr), supra note 482, at 17 (emphasis added):

Th[e] first section [of the Fourteenth Amendment] ... in no manner adds to or changes the power of the Federal government with respect to the protection, against the acts of individuals, of the rights charged in the indictment to have been violated. It does, indeed, add to the power of the Federal government. It puts the States with respect to the prohibition and limitations imposed, under the restraining power of the Federal Constitution. None of the restrictions of the first ten Amendments were applicable to the State governments. The prohibition and limitations of the first section of the Fourteenth Amendment are applicable to the State governments alone.

Marr argued that the Second Amendment did not protect an individual right to keep and bear arms for any lawful purpose, but rather only secured the right of "maintaining, in the States, a well regulated militia," against federal interference. Id. at 26; see also infra note 493 (noting Marr's narrow view of right to assemble).

485 See supra Part II.D. Campbell seemed to take a narrow view in Cruikshank of the rights to assemble and bear arms, even as against the federal government.

The first amendment ... denies power to the United States, to abridge the right of the people to assemble and petition the government for a redress of grievances. But this prohibition contains no implication of control, superintendence, allowance or prevention of such assemblies. The same objections apply to the counts which charge the object of the conspiracy to disturb the exercise of the right to keep and bear arms. This is not a right derived from or secured in the Constitution.... The second amendment... denies to the government power to infringe that 
Notably, Justice Clifford's separate opinion resolved the case without touching on incorporation. Clifford pointed out that the government had abandoned most counts of the indictment. 486 Therefore, he correctly admonished, while "[c]ertain other causes for arresting the judgment are assigned in the record, ... having come to the conclusion that the indictment is insufficient, it is not necessary to consider th[ose] question[s]."487

It seems "ironic," as Professor Palmer noted, that Chief Justice Waite, "under the banner of Slaughter-House," 488 could somehow have eliminated from the scope of the Fourteenth Amendment-at least for the next half-century ${ }^{489}$-one of the very examples of protected privileges and immunities expressly cited by Justice Miller in Slaughter-House. Yet Miller joined Waite's opinion in Cruikshank without protest. Even more paradoxically, so did Justices Bradley and Swayne. Something is clearly amiss somewhere. Defenders of the conventional reading of Slaughter-House might argue that the incorporationist reading of Miller must give way. But that would not explain the Bradley-Swayne about-face.

Newsom purported to resolve the dilemma, in rather startling fashion, by asserting that "Cruikshank is not the anti-incorporationist juggernaut it was once thought to be." ${ }^{.490}$ But how could Cruikshank be consistent with incorporation? Newsom argued in part that the case turned more properly on the state-action issue, ${ }^{491}$ which is certainly true as discussed above, but does not explain Waite's language bearing on incorporation, and indeed, makes it even more troubling. Newsom argued, however, that Waite's discussion of the right of assembly reflected, not a reluctance to incorporate the right as against the states, but rather a

right, and no article in the Constitution... has any relation to that right, except that which relates to the organization and equipment of the militia; the privilege of citizens to keep and bear arms, for a lawful purpose, is not a right or privilege which the United States granted, nor its government charged to guard and to guarantee....

Cruikshank Defendants' Brief (Campbell), supra note 482, at 5-6.

486 Cruikshank, 92 U.S. at 561 (Clifford, J., separate opinion). Clifford stated that counsel for the United States had "confined their arguments entirely to the thirteenth, fourteenth, and sixteenth counts." Id. The fourteenth and sixteenth counts essentially duplicated the allegations of the sixth and eighth counts. See Cruikshank U.S. Brief, supra note 475, at 3. The thirteenth count largely duplicated the sixteenth, except that the thirteenth specified that the victims were denied their rights on account of race. See Cruikshank, 92 U.S. at 557.

487 Cruikshank, 92 U.S. at 569 (Clifford, J., separate opinion); see also id. at 561.

488 Palmer, supra note 22, at 769.

489 It was not until 1925 that the Court began re-incorporating First Amendment freedoms into the Fourteenth Amendment, see Gitlow v. New York, 268 U.S. 652, 666 (1925), and not until 1937 that the rights of assembly and petition were specifically re-incorporated, see De Jonge v. Oregon, 299 U.S. 353, 364 (1937).

490 Newsom, supra note 22, at 720.

491 See id. at $717-20$. 
narrow conception of the right even as applied to the federal government. This conception, which Newsom himself seemed to endorse, is that the First Amendment guarantees, not a right to assemble for any lawful purpose, but rather "the right to assemble for the purpose of petitioning the government."492

Newsom's argument is audaciously defiant of conventional wisdom, and, if tenable, would have great explanatory power. It would reconcile Cruikshank with the incorporationist views and implications of all nine Justices in SlaughterHouse and Justice Bradley in the Cruikshank circuit court opinion. If Newsom had examined the Cruikshank briefs, he would have found some support for his narrow view of the right of assembly in the defendants' arguments. ${ }^{493}$ Unfortunately, however, Newsom's reading of Cruikshank falls apart under scrutiny.

First of all, Newsom did not explain why Chief Justice Waite refused to incorporate the right to bear arms. Newsom acknowledged Waite's antiincorporationist language on the Second Amendment, but did not further discuss the issue. ${ }^{494}$ One might try to explain away this aspect of Cruikshank by arguing that the Second Amendment is uniquely unsusceptible to incorporation, as noted earlier, but Newsom attempted no such argument.

Second, Newsom's theory does not square with a careful reading of Chief Justice Waite's opinion. Newsom overlooked the significance of a critical paragraph, which stated:

The particular amendment now under consideration [the First Amendment, as the preceding paragraph made clear] assumes the existence of the right of the people to assemble for lawful purposes, and protects it against encroachment by Congress. The right was not created by the amendment; neither was its continuance guaranteed, except as against congressional interference. For their protection in its enjoyment, therefore [clearly meaning, in context, protection against anything other than federal power], the people must look to the States. The power for that purpose was originally placed there, and it has never been surrendered to the United States. ${ }^{495}$

492 Id. at 714; see also id. at 714-16.

493 See Cruikshank Defendants' Brief (Marr), supra note 482, at 25-26 (arguing that right of assembly, as applied to either federal government or states, protects only assembly for purpose of petition, not for any lawful purpose); see also Cruikshank Defendants' Brief (Bryon), supra note 482, at 10 (making similar argument); Cruikshank Defendants' Brief (Campbell), supra note 482, at 5-6 (same); supra notes 483 and 485.

494 See Newsom, supra note 22, at 713.

495 Cruikshank, 92 U.S. at 552 (emphases added). 
Waite thus stated quite unambiguously that the federal government is obliged to respect a broad right of assembly "for lawful purposes," but that this right does not apply to the states. 496

Newsom's misstep was to focus too narrowly on Chief Justice Waite's comment (twice cited by Newsom) that "[ $[$ ] he right ... to assemble for lawful purposes existed long before the adoption of the Constitution," 497 and was therefore (according to Newsom) "not... 'granted or secured' by the Constitution." 498 Waite made essentially the same point in the paragraph quoted above, that "[ $t]$ he right was not created by" the First Amendment or the original Constitution. But that was in no way inconsistent with Waite's equally explicit statement, also quoted above, that this right was, nevertheless, "protect[ed]" by the First Amendment "against encroachment by Congress." Legal thinkers of that time often drew a distinction between whether a right was created by the Constitution or merely "declared" and reiterated by it. ${ }^{499}$ Waite was simply acknowledging the historical reality that the right of assembly has a pedigree in Anglo-American law predating 1791. He made clear, in the paragraph quoted above, his belief that the right was also declared, secured, and protected by the First Amendment, though only against federal infringement.

Newsom argued that "Waite seemed frankly to acknowledge the 'incorporating' character of the Fourteenth Amendment'500 in the paragraph (quoted earlier above) that began by referring to "[t]he right of the people peaceably to assemble for the purpose of petitioning Congress for a redress of grievances, or for any thing else connected with the powers or the duties of the national government."501 That paragraph followed immediately after the paragraph (quoted and discussed just above) dealing with the First Amendment. To be sure, that "right of assembly was, according to Waite, 'an attribute of national citizenship." 502 But while Newsom labeled this a "First Amendment

496 See Tribe, Saenz, supra note 20, at 183 n.330.

497 Cruikshank, 92 U.S. at 551, quoted in Newsom, supra note 22, at 713, 714.

498 Newsom, supra note 22, at 713 (quoting Cruikshank, 92 U.S. at 548). Newsom quoted Waite's use of the words "granted or secured" out of context. Waite, laying out the issue presented for decision, was merely quoting the language of the Enforcement Act prohibiting unlawful hindrance of the " free exercise and enjoyment of any right or privilege granted or secured ... by the constitution or laws of the United States." Cruikshank, 92 U.S. at 548.

499 See, e.g., AMAR, BILL OF RIGHTS, supra note 63, at 254-55 n.* ("As we have seen, many of the provisions of the original Bill [of Rights] were seen as 'declaratory' of existing law... and this declaratory theory was one of the driving forces behind the Fourteenth Amendment.").

500 Newsom, supra note 22, at 716.

501 Cruikshank, 92 U.S. at 552.

502 Newsom, supra note 22, at 716 (quoting Cruikshank, 92 U.S. at 552). 
right,"503 that was not Waite's characterization. Waite had referred to the First Amendment in the paragraph quoted and discussed just above, as protecting against federal infringement the right to assemble "for lawful purposes." But in the paragraph quoted earlier, dealing with assembly for the purpose of petitioning the federal government, Waite nowhere alluded to the First Amendment. Instead, he stated that this narrower right of assembly was "implie[d]" by "[t]he very idea of a government, republican in form." 504

As a right to communicate with and seek the protection of the federal government, this narrower right of assembly was probably already shielded by the Supremacy Clause of the original Constitution, 505 with no need of assistance from the Fourteenth Amendment. This analysis is consistent with the government's own argument in Cruikshank, as quoted earlier, that the federal power to protect such rights had existed "at any time since 1789."506 The very way in which Chief Justice Waite chose to characterize the right, as "an attribute of national citizenship,"507 tends to align it with those identified by Justice Miller in Slaughter-House as derived from the "National character" of the federal government, as opposed to those "ow[ing] their existence to the ... Constitution." 508 And it is thus vulnerable to the same charge of redundancy properly leveled against the former (but not the latter) category of privileges and immunities listed by Miller.

It is worth noting that this subject-matter limitation on the right of assembly, as applied to the states by Chief Justice Waite, would be quite unworkable. The implication is that states would be free to suppress peaceable assemblies as a general matter, but obligated to keep hands off any assembly at which "national" issues or appeals to the federal government were discussed or made. Spicing up any given assembly with a few federal issues or appeals would not seem beyond the ingenuity of most activists, so such a limitation might be illusory in any event. But even as a theoretical matter it is offensive to the very concept of free expression pervading the First Amendment, which presupposes that governments, both state and federal, have no business favoring or disfavoring particular subjects of (at the very least) political speech. ${ }^{509}$ Newsom's narrow but

503 Id.

504 Cruikshank, 92 U.S. at 552.

505 U.S. CONST. art. VI, cl. 2.

506 Cruikshank U.S. Brief, supra note 475 , at 6.

507 Cruikshank, 92 U.S. at 552.

508 Slaughter-House, 83 U.S. (16 Wall.) at 79; see also supra Part II.C.

${ }^{509}$ See, e.g., Boos v. Barry, 485 U.S. 312, 321 (1988) (content-based restrictions on speech generally subject to strictest scrutiny); see also Simon \& Schuster, Inc. v. N.Y. State Crime Victims Bd., 502 U.S. 105, 124-28 (1991) (Kennedy, J., concurring) (suggesting that most content-based restrictions are per se invalid). It appears that the only Supreme Court case in which any Justice has attempted to apply Waite's limited conception of freedom of assembly 
fully incorporated version of the right of assembly would presumably protect the right to petition state (and perhaps local) governments as well. But the same basic objections apply.

This author has always understood the First Amendment right of assembly in the broad sense suggested by Chief Justice Waite, as applying to all peaceable assemblies for lawful purposes. Furthermore, this author has always understood the rights of assembly and petition as distinct First Amendment freedoms. Although petitioning the government (any government) is one obvious purpose of the right to assembly protected by the First Amendment, it cannot be so limited without doing violence to plain text. The Amendment declares both "the right of the people peaceably to assemble, and to petition the Government for a redress of grievances," 510 not merely the right to assemble "in order to," or "for the purpose of," petition. Justice Miller in Slaughter-House, echoing the Amendment's language, referred to "[t] he right to peaceably assemble and petition for redress of grievances."511 Justice Bradley referred in Slaughter-House to "the right peaceably to assemble for the discussion of public measures," omitting the right to petition altogether (along with numerous other Bill of Rights guarantees) from his avowedly nonexhaustive list. 512

The above reading is supported by modern usages. In De Jonge v. Oregon, the twentieth-century case incorporating assembly and petition into the Fourteenth Amendment, the Court stated that, "consistently with the Federal Constitution, peaceable assembly for lawful discussion cannot be made a crime." 513 In Edwards v. South Carolina, the Court found that the state had "infringed the ... constitutionally protected rights of free speech, free assembly, and freedom to petition for redress of... grievances." ${ }^{\text {"14 }}$ Leading scholarly works are in accord. 515

under the Privileges and Immunities Clause is Hague v. C.I.O., 307 U.S. 496 (1939). See id. at 511-16 (Roberts, J., joined by Black, J.) (relying on Privileges and Immunities Clause to uphold rights to freely disseminate information concerning, and to peaceably assemble to discuss, federal labor relations statute); id. at 532 (Hughes, C.J., concurring) (agreeing with Roberts on relevant point).

510 U.S. CONST. amend. I (emphasis added).

511 Slaughter-House, 83 U.S. (16 Wall.) at 79 (emphasis added).

512 Id. at 118 (Bradley, J., joined by Swayne, J., dissenting).

513299 U.S. 353, 365 (1937) (emphasis added).

514372 U.S. 229, 235 (1963) (emphases added).

515 See, e.g., AMAR, BIL OF RIGHTS, supra note 63, at 26-30 (discussing Assembly Clause); id. at 30-32 (discussing Petition Clause); id. at 234-36, 244-46 (repeatedly referring disjunctively to rights of speech, press, petition, and assembly); TRIBE 1988, supra note 25 , $\S 11-2$, at 772 (referring disjunctively to "first amendment freedoms of speech, press, assembly, petition, free exercise of religion, and non-establishment of religion"). I cannot purport to have exhaustively researched the understanding of the rights of assembly and petition during the Civil War Era. It appears that some lawyers of the time may have understood them in the way 
Finally, there is an even more fundamental problem with Newsom's reading of Cruikshank. He did not satisfactorily explain Chief Justice Waite's continued reliance on the Barron doctrine to deny that the Bill of Rights applied to the states. Of course, as Newsom emphasized, it was technically correct-even assuming an incorporationist view of the Fourteenth Amendment-for Waite to state that the First and Second Amendments did not of their own force "limit the powers of the State governments." 516 But realistically, why would Waite say such a thing in a case where the Fourteenth Amendment and a federal statute based on it were expressly invoked, and the incorporation issue was squarely presented by the counts of the indictment that Waite chose (however needlessly) to address? This was quite different from cases like Twitchell where "'rights were asserted under the first [eight] amendments only and without reference to the fourteenth."'517 If an incorporationist understanding of the Fourteenth Amendment still prevailed in 1876, it surely would have been recognized that such mechanical reliance on Barron no longer made sense. 518

Newsom does, as reflected in some of the defendants' arguments in Cruikshank cited abovethough Chief Justice Waite and the Justices joining his Cruikshank opinion, as discussed above, do not seem to have shared such a view. Justice Story's Commentaries, as edited by Chief Justice Cooley, treat the rights as one unified clause and emphasize the historical roots of the right of petition, but otherwise provide little guidance. See 2 COOLEY ON STORY 1873, supra note 360 , $\S 1893-1895$, at 619-20; accord COOLEY, CONSTITUTIONAL LIMTATIONS 1874, supra note 363 , at *349 (quoting 2 COOLEY ON STORY 1873, supra note $360, \S 1894$ ).

516 Cruikshank, 92 U.S. at 552; see also id. at 553; Newsom, supra note 22, at 715-16 (discussing Waite's reliance on Barron).

517 Newsom, supra note 22, at 722 (quoting Charles $\mathrm{R}$. Pence, The Construction of the Fourteenth Amendment, 25 AM. L. REV. 536, 542 (1891) (alteration by Newsom)); see also supra Part II.A (discussing Twitchell).

518 Professor Maltz, foreshadowing Newsom to some extent, has also suggested that we should not read Cruikshank too narrowly. But I must demur from Maltz's surprising statement that, "[r]ather plainly, Waite viewed rights such as those protected by the First [and Second] Amendment $[s]$... as the kind of fundamental rights that would be protected [by the Fourteenth Amendment]." Maltz, Concept, supra note 52, at 532. Why, if so, Waite rejected indictments premised on such rights (entirely apart from the state action issues involved), Professor Maltz did not explain. He cited Waite's statement that "the Due Process Clause 'furnishes an additional guaranty against any encroachment by the States upon the fundamental rights which belong to every citizen as a member of society."' Id. (quoting Cruikshank, 92 U.S. at 554). But there is less here than meets the eye. Waite was arguing that the Due Process Clause "adds nothing to the rights of one citizen as against another. It simply furnishes an additional guaranty against any encroachment by the States upon the fundamental rights which belong to every citizen as a member of society." Cruikshank, 92 U.S. at 554. In other words, Waite was merely asserting a state action limitation on the Fourteenth Amendment, without committing himself to any particular scope for it. Likewise, Maltz quoted a passage in which Waite discussed the Equal Protection Clause, which obviously did not go to the substantive scope of any rights, liberties, privileges, or immunities protected by the Amendment. See Maltz, Concept, supra note 52, at 532. Again, Waite's point was simply that the Clause required "only... that the 


\section{CONCLUSION: MAKING SENSE OF THE PUZZLE AND LOOKING AHEAD}

How can we explain the conflicting evidence of the understandings in Congress and the Supreme Court with regard to incorporation of the Bill of Rights? Comments in two cases decided as the 1870s ended, Davidson v. New Orleans ${ }^{519}$ and Missouri v. Lewis, ${ }^{520}$ tend to confirm that, rightly or wrongly, intended or not, explained or not, Edwards, Walker, and Cruikshank effectively unraveled - at least on the Court-the incorporationist consensus seemingly embraced in Slaughter-House. Newsom's suggestion that such a consensus persisted up until Justice Miller's death in $1890^{521}$ is undermined by-in addition to his unpersuasive treatment of Edwards, Walker, and Cruikshank-the fact that he ignored Davidson and Lewis, as well as the 1886 decision in Presser $v$. Illinois. 522

It is true that neither Davidson nor Lewis involved any claim under the Privileges and Immunities Clause, nor was the incorporation issue critical to the decision of either case. But Justice Miller, writing for the Court in Davidson, rejected a challenge to a city tax assessment under the Due Process Clause of the Fourteenth Amendment, and commented:

If private property be taken for public uses without just compensation, it must be remembered that, when the fourteenth amendment was adopted, the provision on that subject, in immediate juxtaposition in the fifth amendment with the Due Process Clause] we are construing, was left out, and this [due process] was taken. ${ }^{523}$

The implication was that the Fifth Amendment Takings Clause was not incorporated. Why would Miller have said such a thing if he understood his Slaughter-House opinion to imply that all privileges and immunities of United States citizens "ow[ing] their existence to the ... Constitution"524 were "taken"

States do not deny the right [to equal protection]. This the [Clause] guarantees, but no more." Cruikshank, 92 U.S. at 555 (emphases added).

51996 U.S. 97 (1878).

520101 U.S. 22 (1880).

521 See Newsom, supra note 22, at 708-09, 732-33; OXFORD SUPREME COURT, supra note 39, at 967 (dates of Miller's tenure).

522116 U.S. 252 (1886); see also Wildenthal, Road to Twining, supra note 4, at Part II.C. Newsom actually quoted Davidson at one point, but still overlooked its anti-incorporationist language - and this was an opinion by Justice Miller himself! See Newsom, supra note 22, at 693.

523 Davidson, 96 U.S. at 105.

524 Slaughter-House, 83 U.S. (16 Wall.) at 79. 
by the Fourteenth Amendment and applied to the states? Ironically, the Takings Clause was found to be incorporated via the Due Process Clause less than twenty years later, in the very first victory on the Court for the incorporation theory. 525 The only Justice who declined to join Miller's opinion in Davidson was, intriguingly, Bradley, who concurred in a short opinion expressing support for the view that the Due Process Clause encompassed the right of just compensation. ${ }^{526}$

Any hope that Davidson marked a return by Justice Bradley to the incorporationist fold was dashed, however, by his unanimous opinion for the Court in Lewis. In that case, a disbarred attorney challenged an odd provision of Missouri law under which cases arising in St. Louis and several other counties, in contrast to the rest of the state, could not be appealed directly to the Missouri Supreme Court, but were instead routed to a special court of appeals. ${ }^{527}$ In rejecting the claim that this violated the Equal Protection Clause, Bradley commented:

The Fourteenth Amendment does not profess to secure to all persons in the United States the benefit of the same laws and the same remedies. Great diversities in these respects may exist in two States separated only by an imaginary line. On one side of this line there may be a right of trial by jury, and on the other side no such right. Each State prescribes its own modes of judicial proceeding. 528

To the extent that Justice Bradley in Lewis may have intended to refer only to civil jury trials, his comment implicitly acknowledged $E d w a r d s$ and Walker. If he intended to speak of both civil and criminal jury trial, he foreshadowed, of course, the Court's later express holding that the Sixth Amendment right to criminal jury trial was not incorporated either. ${ }^{529}$ Neither reading suggests that Bradley and his colleagues-who still included Justices Swayne and Field, his dissenting companions in Slaughter-House, and Justices Miller, Clifford, and Strong from

525 See Chicago, Burlington \& Quincy R.R. Co. v. Chicago, 166 U.S. 226, 241 (1897); Wildenthal, Road to Twining, supra note 4, at Part III.B.

526 Davidson, 96 U.S. at 107 (Bradley, J.). While agreeing with the Court's judgment and the "general tenor of the opinion," Bradley stated that

it narrows the scope of ... due process of law more than it should do.

... If a State, by its laws, should authorize private property to be taken for public use without compensation [subject to some exceptions], I think it would be depriving a man of his property without due process of law.

Id.

527 See Lewis, 101 U.S. at 29-30.

528 Id. at 31.

529 See Maxwell v. Dow, 176 U.S. 581, 595-96 (1900); Wildenthal, Road to Twining, supra note 4 , at Part IV. 
the Slaughter-House majority - had any attachment to incorporation. ${ }^{530}$ It would be difficult to argue that they had forgotten the Privileges and Immunities Clause, for Bradley commented that "[i]t is the right of every State to establish such courts as it sees fit,... provided it... does not abridge the privileges and immunities of citizens of the United States." 531

This passing language in Davidson and Lewis may not provide any firm guide to the views of Justices who merely joined silently in these evidently uncontroversial decisions. The newly appointed Justice Harlan joined both opinions, for example, yet would soon emerge as a powerful champion of total incorporation. 532 Justice Swayne's silent assent to both opinions is more troubling, following his silent concurrences in both Cruikshank and Walker. He must be chalked up as having possibly abandoned the incorporation theory to which he subscribed in Slaughter-House. ${ }^{533}$ And yet, Swayne's consistently strong support over the years for broadly reading and vigorously enforcing the Reconstruction Amendments and civil rights statutes provides room for doubt.534 Swayne, whose son was a Civil War hero who later directed the Freedmen's

530 Justice Hunt from the Slaughter-House majority did not participate in Lewis. He suffered a disabling stroke in December 1878 that prevented him from performing his duties during the remainder of his tenure. He waited to retire until January 1882 when Congress passed a special pension bill for him. See OXFORD SUPREME COURT, supra note 39, at 417; IRONS, supra note 250, at 198. Bradley's Lewis opinion repeated the point about jury trial, stating: "Where part of a State is thickly settled, and another part has but few inhabitants, it may be desirable to have different systems of judicature for the two portions, - trial by jury in one, for example, and not in the other." Lewis, 101 U.S. at 32.

531 Lewis, 101 U.S. at 30.

532 See generally Wildenthal, Road to Twining, supra note 4. Davidson was one of the very first cases in which Harlan participated on the Court. He took his seat on December 10, 1877. OXFORD SUPREME COURT, supra note 39, at 968. Davidson was argued on December 11 and 12, 1877. Davidson, 24 L. Ed. at 616.

533 See supra Part II.D.

534 See Strauder v. West Virginia, 100 U.S. 303 (1880) (joining Court's opinion striking down exclusion of African-Americans from juries); Blyew v. United States, 80 U.S. (13 Wall.) 581, 595-96 (1872) (Bradley, J., joined by Swayne, J., dissenting) (dissenting from Court's narrow interpretation of jurisdictional provision of 1866 Civil Rights Act); United States v. Rhodes, 27 F. Cas. 785 (C.C.D. Ky. 1867) (Swayne, Circuit Justice) (upholding constitutionality of 1866 Civil Rights Act and citizenship of freed slaves under Thirteenth Amendment, in case involving denial of African-American's right to testify against White person); see also Aynes, Miller, supra note 41, at 676 n.359 (noting that Swayne, by then retired, wrote Justice Harlan to congratulate him on his dissent in the Civil Rights Cases, 109 U.S. 3, 26 (1883), which Swayne characterized as "one of the great-indeed one of the greatest-opinions of the Court"); Robert D. Goldstein, Blyew: Variations on a Jurisdictional Theme, 41 STAN. L. REV. 469 (1989) (generally discussing importance of Blyew); id. at 483-87 (discussing Swayne's role in Rhodes); id. at 505-07 (discussing Bradley-Swayne dissent in Blyew). 
Bureau in Reconstruction-Era Alabama, may have had a stronger commitment than Justice Bradley to honoring the true meaning of the Reconstruction Amendments. ${ }^{535}$ How would Swayne have ruled on Hurtado v. California ${ }^{536}$ or O'Neil v. Vermont? ${ }^{537}$ We will never know. He retired in 1881 and died three years later. ${ }^{538}$ Justice Field's views on incorporation remained a riddle during the 1870s after Slaughter-House. His silent assents to Cruikshank, Davidson, and Lewis suggest little attention to the issue. He did dissent in Walker, but probably, as we have seen, on other grounds.

As for Justice Miller and his majority colleagues in Slaughter-House, none ever showed any lingering loyalty to the incorporationist implications of the opinion they joined in 1873. Justice Miller himself, as we have seen, wrote the opinion in Davidson and joined silently in Cruikshank, Walker, and Lewis. He never showed any sign of wanting to resurrect a broader reading of the Fourteenth Amendment. The same goes for Justices Davis, Strong, and Hunt, who all joined Cruikshank and Walker and retired in 1877, 1880, and 1882, respectively. ${ }^{539}$ Justice Clifford, as we have seen, dissented in Walker (but almost certainly not on incorporationist grounds) and concurred separately in Cruikshank (avoiding the incorporation issue), but wrote the opinion in Edwards and joined silently in Davidson and Lewis. He died in office in 1881.540

What went wrong? Chief Justice Waite's mishandling of the incorporation issue in both Cruikshank and Walker is perhaps explainable to a slight extent by the fact that he alone on the 1874-76 Court had not been on the bench when Slaughter-House was decided in $1873 .{ }^{541}$ But that was no hindrance to the members of Congress who discussed the incorporationist meaning of SlaughterHouse in 1873-74.542 In assessing Waite's handiwork, we should perhaps also keep in mind that, when appointed Chief Justice-he was President Grant's seventh choice for the job! - he was "an undistinguished [real estate] lawyer" with "no judicial experience," and was later described by Justice Field as "an experiment which no President has a right to make with our Court." 543 But where were the other Justices who had presided in Slaughter-House? Was this sheer

535 See Aynes, Miller, supra note 41, at 674-76.

536110 U.S. 516 (1884); see also Wildenthal, Road to Twining, supra note 4, at Part II.B.

537144 U.S. 323 (1892); see also Wildenthal, Road to Twining, supra note 4, at Part III.A.

538 OXFORD SUPREME COURT, supra note 39, at 850-51.

539 Id. at 967 . Strong and Hunt joined silently in Davidson as well, as did Strong in Lewis.

See supra notes 523-31 and accompanying text.

540 OXFORD SUPREME COURT, supra note 39 , at 967.

541 Id.

542 See supra Part III.A.1.

543 IRONS, supra note 250, at 201-02. 
carelessness and inattention? Did the heavy backlog of cases on the Justices' docket at the time tempt them to cut back on federal causes of action whenever possible, even at the cost of trampling principles of judicial restraint and cursorily nullifying a recently adopted constitutional amendment? ${ }^{544}$

It is tempting to try and draw a connection between this turnabout on incorporation and the disputed presidential election of 1876, which effectively ended the Reconstruction Era. Professor C. Vann Woodward provided the classic account of the crisis of 1876-77 and the Compromise of 1877 that resolved it. 545 Democratic New York Governor Samuel J. Tilden defeated Republican Ohio Governor Rutherford B. Hayes in the popular vote and received undisputed electoral votes amounting to one short of a majority. The returns from Florida, Louisiana, and South Carolina, and one electoral vote in Oregon, were in dispute. Overheated partisan and sectional rhetoric, with amply justified cries of fraud and deceit on both sides, threatened renewed civil war..$^{546}$

The presidency was secured for Hayes, and the threat of violent Democratic resistance defused, by a complex series of negotiations and compromises between, on the one hand, Northern Republicans allied with Hayes and certain railroad interests, and on the other, Southern Democrats anxious to promote economic development and complete the White-supremacist "redemption" of the South from Reconstruction. The key concessions to the Southern Democrats were promises to (1) withdraw the remaining federal troops in the South from any involvement in local political struggles, and in particular, allow disputed Democratic governors to take office in Louisiana and South Carolina, (2) appoint a Southern Democrat to the plum patronage Cabinet position of Postmaster General, and (3) support federal subsidies for internal improvements benefiting the South, most notably a new southern railroad route to the Pacific. .47

The Supreme Court became embroiled in the crisis when Congress established a fifteen-member Electoral Commission in January 1877 to resolve the disputed returns. Five members were chosen from the House and five from the Senate, evenly divided between the parties. Four Justices, Republicans Swayne and Strong and Democrats Clifford and Field, were named to the Commission, and those four were authorized to appoint a fifth. It was generally assumed that this fifteenth and tie-breaking member of the Commission would be Justice Davis, who was regarded as an independent. But then, in a bizarre turn of

544 Cf. KACZOROWSKI, POLIIICS, supra note 88, at 225 (noting two-year backlog on Court's docket around this time).

545 See generally WOODWARD, supra note 323; see also FONER, supra note 88, at 564 87; FRANKLIN, supra note 88, at 203-10.

546 See WOODWARD, supra note 323, at 16-21; FONER, supra note 88, at 575-76.

547 See WOODWARD, supra note 323 , at 22-149, 166-203; FONER, supra note 88, at 57782. 
events, the Illinois state legislature elected Davis to the Senate and he declared himself unavailable to serve on the Commission. ${ }^{548}$

Justice Bradley, a Republican like all the remaining members of the Court, was appointed to the Commission in Justice Davis's stead. He proceeded to cast the decisive vote in a series of 8-7 rulings upholding the returns favoring Hayes. Bradley's reputation was severely tarnished in the process, not only by the partyline nature of the Commission's votes, but also by allegations--never proven but also never quite convincingly rebutted-that, after initially writing an opinion in favor of Tilden, he changed his vote at the last minute under improper pressure or influence. ${ }^{549}$ Despite the renewed uproar this triggered, the forces of compromise prevailed. Congress accepted the Commission's verdict and declared Hayes the winner with barely a day to spare before the new presidential term began on March 4, 1877.550

This is all very interesting, of course, and it is certainly intriguing that Justices Bradley and Swayne - two of the strongest incorporationists of the early 1870 s-played such a prominent role, along with fellow Slaughter-House dissenter and future incorporationist Justice Field. But does it have anything to do with the incorporation issue? Was it the Compromise of 1877 that snuffed out the "Lost Compromise" described in this article? There does not seem to be any reason to think so. The timing is off, for one thing. As discussed in Parts III.B and III.C, the Court had already seemingly abandoned the incorporationist consensus of the early 1870s in Cruikshank and Walker, decided in March and April 1876, almost a year before the Hayes-Tilden election crisis and the Justices' involvement with the Electoral Commission.

Furthermore, incorporation was not a likely candidate to play a role in the reaction against Reconstruction that came to a head in 1876-77. Far from it. Southern Democrats themselves, as described in Part III.A.1, had recently and forcefully articulated a textualist theory of total incorporation of the Bill of Rights-repeatedly citing Slaughter-House as support-as their preferred limiting construction of the Fourteenth Amendment. Federal enforcement of the freedmen's voting rights, equal access to civil rights in the public and private

548 See WOODWARD, supra note 323, at 150-54. Davis was a close friend of President Abraham Lincoln and managed his presidential campaign in 1860. Lincoln appointed him to the Supreme Court in 1862. Davis resigned from the Court on March 4, 1877, the same day he took office as a senator. His successor on the Court was Justice Harlan. See OXFORD SUPREME COURT, supra note 39, at 218-19, 362, 967; U.S. ElECTIONS, supra note 294, at 790. Ironically, it appears that Democrats in the Illinois legislature backed Davis under the belief that this would incline him to favor Tilden on the Commission. See WOODWARD, supra note 323, at 153-54. They outsmarted themselves, however, because the result, as noted in text, was victory for Hayes.

549 See WoODWARD, supra note 323, at 154-63.

550 See generally id. at 163-203. 
sectors, and the battle against the $\mathrm{Ku} \mathrm{Klux} \mathrm{Klan} \mathrm{and} \mathrm{other} \mathrm{state-sponsored} \mathrm{and}$ private terrorism against African-Americans were all far more prominent flashpoints during the 1870 s. ${ }^{551}$

The continuity in this regard with the debates of 1866-68, when the Fourteenth Amendment was framed and adopted, is striking when viewed in perspective. As other scholars have explored at length, the late 1860 s were racked by intense debates over such matters as whether African-Americans should be granted voting rights and whether the Civil Rights Act of 1866 should be enacted or was constitutional. ${ }^{552}$ By contrast, as summarized in Part I.B, incorporation of the Bill of Rights against the states, while strongly advocated by such men as Bingham and Howard and certainly a foundation stone in Republican efforts to extend federally guaranteed rights to the South, was simply not at the crest of controversy. Not a single voice in Congress seems to have clearly disputed, during the decade from 1866 to 1875 , that the Fourteenth Amendment would and did accomplish (at least) incorporation of textual constitutional guarantees as applied to state action. The incorporation theory became, by the early 1870 s, a zone of consensus between Republicans and Democrats-a calm eye in the constitutional and political hurricanes of the Reconstruction Era.

But returning to the puzzle of the late 1870 s, exactly when, where, and why did this compromise become lost? Professor Crosskey favored the rather Machiavellian theory that Justice Miller and his Slaughter-House colleagues intended and plotted all along for that opinion, and the Privileges and Immunities Clause it construed, to be gutted as Chief Justice Waite seemed to accomplish in Cruikshank In Crosskey's view, the Slaughter-House opinion was "most craftily written ... so as to enable the Court, with a good face, in future cases, to jump either way: to observe the intended meaning of the ... Clause if that seemed unavoidable, or, in the altemative, to destroy the clause utterly if this seemed safe." 553

This author tends to the view that we should not credit the Justices with too much foresight or attention to the incorporation issue. It was probably not uppermost in their minds. Justice Miller's language in Slaughter-House was most likely ambiguous and sketchy simply because incorporation was an uncontroversial side issue far removed from the dispute at bar. It should have been a complete nonissue in Edwards, Walker, and Cruikshank. To the extent it got botched in those cases, this would seem to confirm the age-old wisdom that courts should not reach out to address issues not pressed before them or necessary note 88.

551 See generally, e.g., KACZOROWSKI, POLIIICS, supra note 88.

552 See generally, e.g., JAMES, FRAMING, supra note 88; JAMES, RATIFICATION, supra

5532 CROSSKEY, POLMTCS, supra note 49, at 1130; see also id. at 1129 (describing incorporationist dicta in Slaughter-House as both "ambiguous" and "evasive"). 
to their decisions. 554 Carelessness and inattention, coupled with a generic and growing inclination to limit federal judicial power and obligations whenever possible, may be the most likely culprits, however boring and unsatisfactory such an explanation may seem.

But does this unraveling consensus on incorporation in the decade after Slaughter-House tend to disprove the incorporationist reading of SlaughterHouse itself? This is perhaps the strongest ground on which to challenge the thesis set forth in this article. One of the greatest claims to virtue of any theory is that it has explanatory power, that it reduces the sum total of confusion and uncertainty in the universe. The unorthodox reading of Slaughter-House urged here resolves, to some extent, the apparent puzzle of why Miller, a Republican Justice writing for a Republican-dominated Court, 555 would (as depicted under the orthodox reading) slaughter a key Clause of the Republican-backed Fourteenth Amendment. This article argues that the majority was not guilty of any such crime, at least in 1873-that the Slaughter-House decision did not live up to its name. 556

This reading, however, concededly generates other questions. If that was what Justice Miller intended or understood, why did he and his colleagues seem to abandon that reading so soon, and with so little explanation? I myself have not been able to answer this question to my own full satisfaction. But it bears emphasizing that there is really nothing new about the puzzle of why certain Justices seem to have flip-flopped on the incorporation issued during the $1870 \mathrm{~s}$. The apparent change of heart by Miller and his majority colleagues may forever remain a puzzle. But it is no more a puzzle (in fact, arguably less so) than why Justices Bradley and Swayne-whose incorporationist credentials in SlaughterHouse are not in doubt-seemed to tum tail by 1876. Orthodox and unorthodox readers of Slaughter-House alike are in the same boat on that one.

Defenders of the orthodox reading might argue that the supposed Miller flipflop is more troubling than the Bradley-Swayne about-face. Perhaps Bradley and

554 See supra note 122.

555 Throughout 1873-77, six of the nine Justices were Republicans (Chief Justice Chase and then his successor, Chief Justice Waite, and Justices Bradley, Hunt, Miller, Strong, and Swayne). OXFORD SUPREME COURT, supra note 39, at 81 (Bradley); id at 136 (Chase); id. at 417 (Hunt); id. at 548 (Miller); id. at 846 (Strong); id. at 850 (Swayne); id. at 906 (Waite); see also id. at 967 (table of Justices and their tenures). Justice Davis was generally viewed as an independent, but he was appointed by the first Republican President, Lincoln, whose presidential campaign he had managed. See supra note 548 and accompanying text. Justices Clifford and Field were Democrats, but Field was a Unionist Lincoln appointee and, as we have seen, generally favored a broad reading of the Fourteenth Amendment. OXFORD SUPREME CoURT, supra note 39, at 161 (Clifford); id. at 290 (Field).

556 Cf. BRANT, supra note 22, at 347 (arguing that Slaughter-House "was truly a slaughter of the Constitution as far as privileges and immunities were concerned"). 
Swayne merely acceded to the majority view from which they dissented in Slaughter-House. They gave up. So what? That's not unheard of for dissenters. But Bradley had not given up by 1874 , when he wrote his incorporationist circuit court opinion in Cruikshank ${ }^{557}$ Furthermore, as discussed in the sequel to this article, Bradley (along with Field) remained emphatically unreconciled to what they saw as the actual point of dispute between the Slaughter-House majority and dissenters as late as 1884, when the Court revisited Slaughter-House in a case involving Louisiana's repeal of the very same disputed monopoly. 558

This author tends to suspect that there was some deeper current at work, perhaps unplanned and unintended, that shifted the tide away from the incorporationist consensus of Slaughter-House and the early 1870s. This tide was obviously strong enough to sweep up even once-emphatic incorporationists like Justice Bradley. It thus seems less surprising that it would carry along those, like Justice Miller and his Slaughter-House majority colleagues, who-it should be conceded-were probably never that strongly attached to the incorporation theory in the first place. Justices Field and Harlan, of course, would later fight back against that tide, but that story is best left to the sequel.

Focusing on what Miller or other Justices personally intended or believed is ultimately somewhat beside the point in any event. 559 Whether Miller or any other Justice personally supported incorporation at any given time is not that important. What is important is that all the Justices in Slaughter-House wrote or joined opinions which, taken together in historical context, are most reasonably read to recognize-as minimum common ground-the incorporationist understanding of the Fourteenth Amendment. What is equally important is that they were in fact so read by many of their contemporaries, including leaders across the political spectrum in a coequal branch of government.

* * * *

The thesis of total incorporation of all, but only, rights textually guaranteed by the Constitution has been, and will continue to be, subject to attack from

557 See supra Part III.C.

558 See Butchers' Union Slaughter-House and Live-Stock Landing Co. v. Crescent City Live-Stock Landing and Slaughter-House Co., 111 U.S. 746, 746-54 (1884) (opinion of the Court by Miller, J., upholding repeal while noting validity of monopoly was upheld in 1873 Slaughter-House decision); id. at 754-60 (Field, J., concurring in upholding repeal on grounds that monopoly was inherently invalid as contended in his 1873 Slaughter-House dissent); id. at 760-66 (Bradley, J., concurring) (same); see also Wildenthal, Road to Twining, supra note 4, at Part II.C.

559 Cf., e.g., Newsom, supra note 22, at 687-88 (properly recognizing that his exploration of "Miller's personal judicial philosophy" is ultimately "relevant only insofar as it sheds light on the proper understanding of the text of the Court's opinion"). 
opposite sides by scholars of the original understanding: 560 both by those contending that it reads too much into the Privileges and Immunities Clause, and those contending that it reads too much out. As suggested in Part II.E, the thesis is, in reality, much more vulnerable to the latter criticism than to the former. For reasons discussed in Part II.E, there are strong textual arguments for so limiting the Clause. But there is, admittedly, something a bit circular in arguing that the text must necessarily be limited by the text. Professor Laurence Tribe has noted "the simple but ultimately deep problem of self-referential regress whenever one seeks to validate, from within any text's four corners, a particular method of giving that text meaning." 561

Many of us today may be textualists and positivists, but who is to say that those of the Civil War generation were? In fact, many, perhaps most of them, were not. ${ }^{562}$ They were highly enamored of vague and lofty principles of natural law untethered to positive text. Like Justice Field, they "require[d] no aid from

560 This article and its sequel, see supra note 4 , having more than enough on their plates already, do not generally attempt to address the broader theoretical issues regarding the propriety of originalist (historical) and nonoriginalist approaches to constitutional interpretation. For an overview of those issues, see, e.g., Paul Brest, The Misconceived Quest for the Original Understanding, 60 B.U.L. REV. 204 (1980), H. Jefferson Powell, The Original Understanding of Original Intent, 98 HARV. L. REV. 885 (1985), Earl M. Maltz, The Failure of Attacks on Constitutional Originalism, 4 CONST. COMM. 43 (1987), Richard S. Kay, Adherence to the Original Intentions in Constitutional Adjudication: Three Objections and Responses, 82 Nw. U. L. REV. 226 (1988), Antonin Scalia, Originalism: The Lesser Evil, 57 U. CIN. L. REV. 849 (1989), Daniel A. Farber, The Originalism Debate: A Guide for the Perplexed, 49 OHO ST. L.J. 1085 (1989), and Randy E. Barnett, An Originalism for Nonoriginalists, 45 LOY. L. REV. 611 (1999). For an excellent overview of the relationships and distinctions between historical/originalist and textualist approaches to constitutional interpretation, see PHILIP BOBBIT, CONSTITUTIONAL FATE: THEORY OF THE CONSTITUTION 9-38 (1982). My present articles are written on the assumption that historical evidence relevant to the original understanding has at least some importance to most scholars (and judges and practicing lawyers) concemed with constitutional issues-even those who (like myself) are skeptical of how such evidence is sometimes used. I do, obviously, argue that the historical evidence discussed in these articles supports the incorporation of the Bill of Rights in the Fourteenth Amendment to (at least) the degree currently recognized by the Supreme Court. I plan to pursue in future articles more theoretical questions regarding the significance and proper use of historical evidence in interpreting the Constitution.

561 Tribe, Comment, in A MATTER OF INTERPRETATION, supra note 12, at 65, 76.

There is certainly nothing in the text itself that proclaims the Constitution's text to be the sole or ultimate point of reference-and even if there were, such a self-referential proclamation would raise the problem of infinite regress and would, in addition, leave unanswered the very question with which we began: how is the text's meaning to be ascertained?

Id. at 77-78.

562 See supra Parts II.C-E; ANTIEAU, supra note 266, at 47-63, 207-30; BOND, supra note 82, at 255-57. See generally Olson, supra note 266; Smith, Natural Law, supra note 147. 
any bill of rights"563 to defend the "sacred and imprescriptible rights of man."564 Many, perhaps most, Civil War-Era legal thinkers may have found a textualist vision of law incapable of fully protecting the rights they held dear. Can we faithfully, or even coherently, interpret the amendments they authored and ratified without honoring their way of thinking about the law itself? At the same time, as discussed in Part II.E, many of that generation, even Republicans committed to fundamental change, adhered to a traditional, limited view of federal judicial power.

It is a difficult problem, but not intractable. It has long been persuasively argued that the very legitimacy of judicial review in our democratic society demands that judges adhere to a textualist approach to the Constitution. ${ }^{565}$ Such a view was widely, though not universally, embraced by the Constitution's founding generation, and in any event, undergirds the logic, and more importantly, the legitimacy, of judicial review as set forth by Chief Justice John Marshall in Marbury v. Madison. ${ }^{566}$ As Marshall reasoned:

The powers of the legislature are defined and limited; and that those limits may not be mistaken or forgotten, the constitution is written. To what purpose are powers limited, and to what purpose is that limitation committed to writing, if these limits may, at any time, be passed by those intended to be restrained? 567

\section{And as Justice James Iredell argued five years earlier in Calder v. Bull: 568}

If any act of Congress, or of the Legislature of a State, violates ... constitutional provisions, it is unquestionably void.... If, on the other hand, [any] Legislature... shall pass a law, within the general scope of their constitutional power, the Court cannot pronounce it to be void, merely because it is, in their judgment, contrary to the principles of natural justice. The ideas of natural justice are regulated by no fixed standard: the ablest and the purest men have differed upon the subject; and all that the Court could properly say, in such an event, would be, that the Legislature (possessed of an equal right of opinion) had passed an act which, in the

563 Slaughter-House, 83 U.S. (16 Wall.) at 111 (Field, J., dissenting).

${ }^{564} \mathrm{Id}$. at 110 (Field, J., dissenting).

565 See, e.g., ELY, supra note 6, at 8-9. In a nutshell, textualism "supports judicial review while answering the charge that the practice is undemocratic," because the judges are, by definition, merely enforcing the higher law decreed by the people. See id. at 9 (quoting Thomas Grey, Do We Have an Unwritten Constitution?, 27 STAN. L. REv. 703, 705 (1975)); see also, e.g., BLACK, supra note 173 , at 18-21.

5665 U.S. (1 Cranch) 137, 176-80 (1803).

567 Id. at 176; see also BLACK, supra note 173, at 18-19 (quoting and discussing this language in Marbury).

5683 U.S. (3 Dall.) 386 (1798). 
opinion of the judges, was inconsistent with the abstract principles of natural justice. 569

Some form of textualism was thus, at least arguably, part of the original constitutional "deal." Later amendments to the Constitution have necessarily been framed and adopted by later generations, in at least one case by combinations of generations stretching across the ages. 570 Certainly any honest understanding and application of such amendments requires that we take into account the conceptions and attitudes of the generations that framed and adopted them. But ultimately they must be interpreted, not as freestanding documents from a given age, but as integral parts of a single Constitution that both predates and postdates them. They may have been their amendments, but they became part of our Constitution. As Professor Steven Calabresi has commented, we should "read the Fourteenth Amendment in light of the federalism and separation of powers values that suffuse the whole of the original Constitution." 571

The theory of total and textual incorporation fits that bill perfectly. It accomplishes much of what the post-Civil War Reconstructionists wanted in the way of limiting state authority to abuse the fundamental rights and liberties of free citizens. But it does so squarely within the secure and traditional premises of antebellum constitutional theory reflected in Calder and Marbury. If today's Supreme Court is to take up the invitation of Justice Thomas and Chief Justice Rehnquist in Saenz v. Roe $e^{572}$ and reassess the conventional view of SlaughterHouse and the Privileges and Immunities Clause, why should the Justices of today not arrive at where their forebears began in $1873 ?^{573}$ Why should they be

569 Id. at 399 (separate opinion of Iredell, J.). Justice Samuel Chase's lead opinion (speaking only for himself), see id. at 386-95, has traditionally been viewed as embracing a natural law ideology diametrically opposed to Iredell's textualism. See, e.g., GUNTHER \& SULLIVAN, supra note 25, at 454-56. Dean Ely, however, has argued that a close reading of Chase's opinion indicates that, while he spoke in terms of natural justice, Chase, like Iredell, only supported the exercise of judicial review when a violation of constitutional text was shown. See ELY, supra note 6, at 209-11 n.41.

570 See GUNTHER \& SULLIVAN, supra note 25, at app. A-15 n.** (describing ratification of Twenty-Seventh Amendment, U.S. CONST. amend. XXVI, which was proposed in 1789, but not ratified until 1992).

571 Calabresi, supra note 63, at 2304.

572526 U.S. 489, 521-28 (1999) (Thomas, J., joined by Rehnquist, C.J., dissenting); see also supra Part I.A (quoting and discussing Saenz).

573 The fact that the states have relied for more than a century on the Court's disincorporation of the rights to civil jury trial (in Edwards and Walker, see supra Part III.B) and grand jury indictment (in Hurtado v. California, 110 U.S. 516 (1884), see Wildenthal, Road to Twining, supra note 4, at Part II.B)-to the point of substantially restructuring their civil and criminal justice systems-does furnish a persuasive argument for respecting stare decisis in 
unable to embrace the consensus achieved between radical progressives like Senator Howard and obdurate conservatives like Senator Norwood? Why should they not resurrect the compromise that once was lost but has now again been found?

those regards. But bowing out of necessity to Walker and Hurtado does not undermine the legitimacy or feasibility of otherwise total incorporation of the Bill of Rights. 
